\title{
O PARQUE NACIONAL DA CHAPADA DOS VEADEIROS COMO DESTINO ECOTURÍSTICO
}

Benita Maria Monteiro Mueller Rocktaeschel

Manoel Cláudio da Silva Júnior

Monografia apresentada ao Centro de
Excelência em Turismo da
Universidade de Brasília como
requisito parcial para a obtenção do
certificado de Especialista em
Ecoturismo

Brasília, DF, abril de 2003 
UNIVERSIDADE DE BRASÍLIA

Centro de Excelência em Turismo

Curso de Especialização em Ecoturismo

\section{O PARQUE NACIONAL DA CHAPADA DOS VEADEIROS COMO DESTINO ECOTURÍSTICO}

Benita Maria Monteiro Mueller Rocktaeschel

Banca Examinadora

Manoel Cláudio da Silva Júnior, Doutor

Orientador

Fábio de Jesus, Mestre

Membro da Banca

Brasília, DF, 30 de abril de 2003 
Rocktaeschel, Benita Maria Monteiro Mueller

O Parque Nacional da Chapada dos Veadeiros como Destino

Ecoturístico / Benita Maria Monteiro Mueller Rocktaeschel

xi, 72p. : il.

Monografia (especialização) - Universidade de Brasília. Centro de Excelência em Turismo. Brasília, 2003.

1. Ecoturismo 2. Meio-Ambiente 3.Turismo 
Benita Maria Monteiro Mueller Rocktaeschel

\section{O PARQUE NACIONAL DA CHAPADA DOS VEADEIROS COMO DESTINO ECOTURÍSTICO}

Comissão Avaliadora

\begin{tabular}{c}
\hline $\begin{array}{c}\text { Manoel Cláudio da Silva Júnior, Doutor } \\
\text { Orientador }\end{array}$ \\
\hline Fábio de Jesus, Mestre \\
Membro da Banca \\
\end{tabular}

Brasília, DF, 30 de abril de 2003 
"Há muito que eu não sei, mas não há nada que eu não possa aprender". GANDHI 


\section{AGRADECIMENTOS}

Ao Programa de Desenvolvimento do Ecoturismo na Amazônia Legal (PROECOTUR), Secretária de Coordenação da Amazônia do Ministério do Meio Ambiente que propiciou minha participação no Curso.

Agradeço ao amigo e ex-coordenador do PROECOTUR Ricardo José Soavinski, que me incentivou e permitiu que eu tivesse a oportunidade de aprender mais sobre ecoturismo.

Ao Instituto Brasileiro do Meio Ambiente e dos Recursos Naturais Renováveis (IBAMA), nas pessoas do José Lázaro de Araújo Filho, Antonia Lúcia Monteiro, Vitória Evangelista Monteiro, Augusta Rosa Gonçalves, Inês de Fátima Oliveira e Valquiria Gonçalves, que disponibilizaram informações que muito contribuíram para este estudo.

Aos meus amigos, Chefes de Parques Nacionais, Jovelino Muniz, Léo Nascimento, Estevão José Fonseca, Claudio Bellinni, Sônia Peixoto e Fernando Athaíde, que sempre me incentivaram e disponibilizaram com presteza, informações sobre suas Unidades.

Ao Professor Manoel Cláudio, coordenador do curso, orientador e amigo que tanto contribuiu com suas críticas e considerações na elaboração do trabalho e com quem muito aprendi sobre o viver aquilo em que se acredita.

Aos professores das disciplinas cursadas, que propiciaram a ampliação dos meus conhecimentos.

Aos funcionários do Centro de Excelência em Turismo (CET), principalmente na pessoa da Graça, do Pedro e do Fernando que com sua simpatia e disponibilidade fizeram com que o tempo passasse mais rápido.

Aos funcionários do IBAMA, Parque Nacional da Chapada dos Veadeiros, na pessoa da Rosa Lia, Carmem Florêncio, Roberto, Otaciano que me acolheram com atenção especial quando de minhas pesquisas de campo.

A comunidade de Alto Paraiso e São Jorge, principalmente na pessoa da Rosa, Téia, Roberto e Tereza, que me acolheram com tanto carinho e hospitalidade.

À colega e amiga Lourdes M. Ferreira que me incentivou, orientou e ofereceu importantes contribuições lendo e revisando a versão preliminar deste trabalho.

Aos amigos e colegas do PROECOTUR, pelo apoio, cooperação e incentivo na busca do conhecimento. 
À minha família, pela paciência, compreensão que tiveram com minha ausência durante todo o ano do curso e principalmente quando da elaboração desta monografia.

À minha filha Flávia e minha irmã Lúcia, que se dispuseram a me acompanhar em minhas visitas de campo e me auxiliar em minhas pesquisas.

Em especial ao meu marido Ricardo, que me ajudou na revisão e ainda elaborou com presteza os gráficos e a formatação deste estudo.

A todos que direta ou indiretamente colaboraram para que eu obtivesse os dados necessários para o estudo e conclusão do presente trabalho. 


\section{RESUMO}

Este trabalho teve por objetivo o estudo do Parque Nacional da Chapada dos Veadeiros (PNCV), no Estado de Goiás enquanto atrativo maior do Pólo de Ecoturismo daquela região. Tal estudo se justifica pelo fato de o PNCV ser um dos parques de maior visibilidade no país, com imenso potencial para o ecoturismo e conseqüentemente para a geração de benefícios econômicos, ambientais e de educação para a comunidade de seu entorno, para a própria unidade e para o Sistema Nacional de Unidades de Conservação (SNUC). Dois pontos apresentam-se fundamentais para esse estudo: A situação atual do Parque com respeito ao seu Plano de Uso Público (PUP) e sua colocação no mercado nacional e internacional como produto ecoturístico do Pólo. A metodologia utilizada consta da revisão da literatura, pesquisa de campo com visitantes, visitas ao PNCV, e entrevistas e reuniões com entidades e pessoas ligadas ao parque. São apresentados e discutidos os instrumentos de planejamento da unidade, os conceitos que norteiam a proposta de produtos ecoturísticos, os pontos positivos dessa inserção e as necessidades para sua efetiva concretização. A conclusão do presente estudo aponta no sentido da urgente necessidade de dotar o Parque Nacional de infra-estrutura que permita aos visitantes o conhecimento, com qualidade, da riqueza natural existente e garanta o mínimo impacto ambiental, ao mesmo tempo que propicie o desenvolvimento sócioeconômico da comunidade do seu entorno, através da utilização dos recursos naturais de forma sustentável. Desta forma sugestões e recomendações são apresentadas para a orientação de ajustes que permitam ao PNCV atingir suas principais metas através do melhor relacionamento com as comunidades locais e com o estabelecimento de parcerias com outros setores da sociedade. 


\begin{abstract}
The aim of this work was to study the 'Chapada dos Veadeiros' National Park (PNCV), Goiás state, Brazil, as the main regional ecotourism destination. The PNCV is one of the most visited national parks in Brazil. It shows a great potential to generate regional economic, social and environmental benefits and also to the Park and to the Brazilian National Conservation Units System (SNUC). Two main points are presented as important in the current Park situation: it's Plan for Public Use (PUP) and its position as national and international ecotourism product. Methods included literature review, field study and meetings and interviews with visitors, institutions administrators. Results include presentation and discussion of the park planning instruments and the positive aspects which may help the construction of an ecotourism product in the park. Conclusions indicate the urgent need of adequate infrastructure for ecotourism in PNCV to allow access to its natural richness with minimum environmental impacts. In this way it would be possible to enhance social environmental and economic development to local communities. Guidelines are presented to subsidize adjustments in order that PNCV main targets may be reached through a better relationship with local communities and establishment of partnerships with other sector of society.
\end{abstract}


SIGLAS E ABREVIATURAS …..........................................................................ii

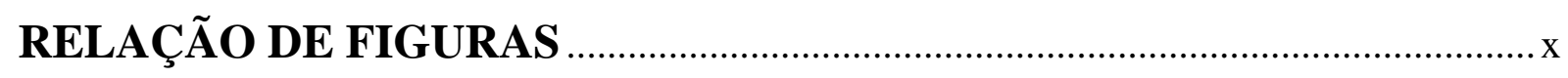

RELAÇÃO DE TABELAS ….............................................................................

1 INTRODUÇÃ

2 REVISÃO BIBLIOGRÁFICA ………………....................................... 4

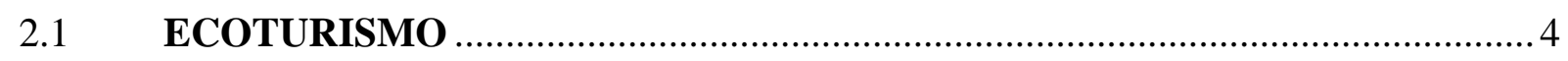

2.2 UNIDADES DE CONSERVAÇÃO/PARQUES NACIONAIS ………….............. 9

2.3 TERCEIRIZAÇÃ̃ EM UNIDADES DE CONSERVAÇÃ̃.............................. 12

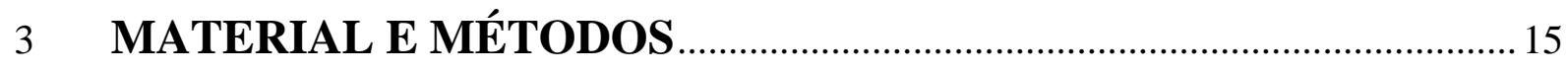

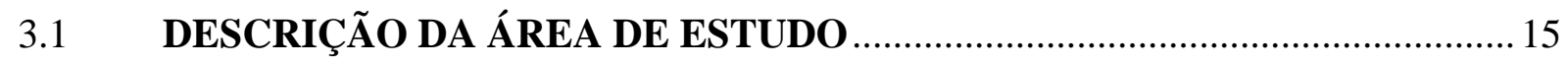

3.1.1 Aspectos gerais do Parque Nacional da Chapada dos Veadeiros..................... 15

3.1.1.1 Informações gerais sobre a Unidade …………………………………….... 15

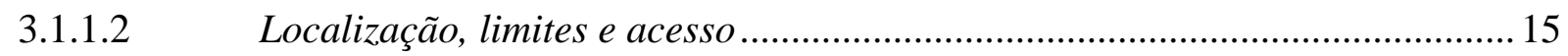

3.1.2 Características sociais, econômicas e culturais ................................................ 18

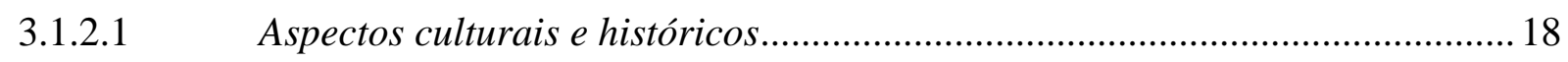

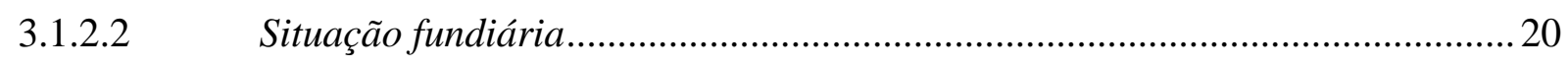

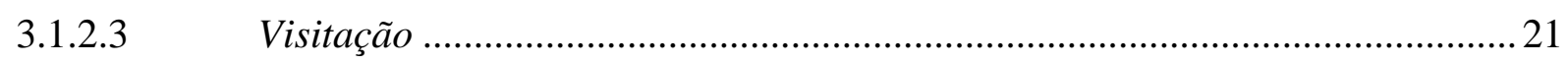

3.1.3 Caracterização Biofísica do Parque Nacional da Chapada dos Veadeiros .... 22

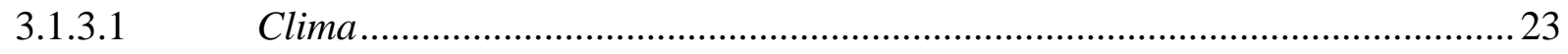

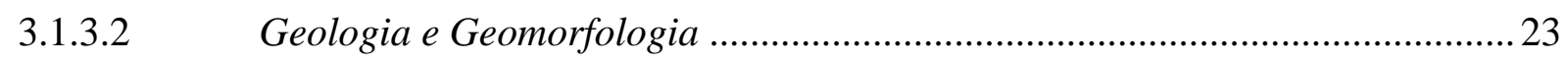

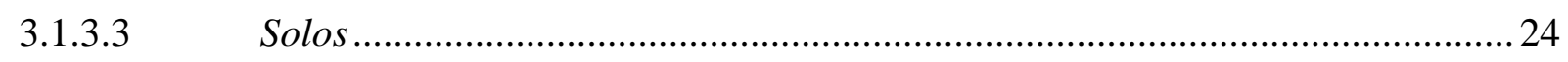

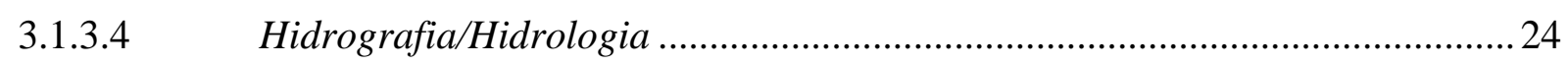

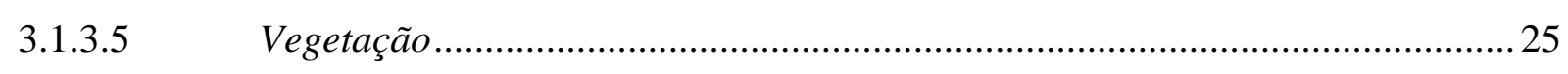

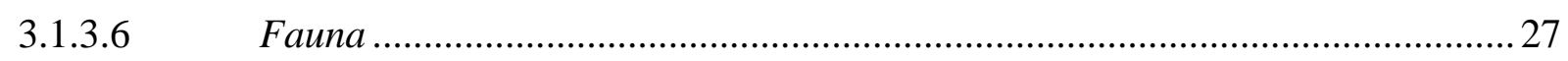

3.2 INSTRUMENTOS DE MANEJO OU USO DA ÁREA DA UNIDADE DE

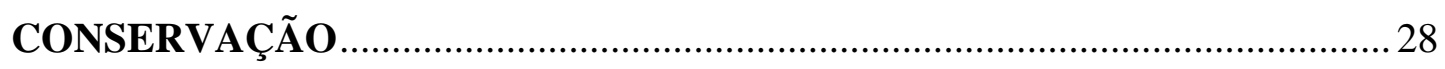

3.2.1 Plano de Manejo do Parque Nacional da Chapada dos Veadeiros ………….. 28

3.2.2 Plano de Uso Público do Parque Nacional da Chapada dos Veadeiros........... 32

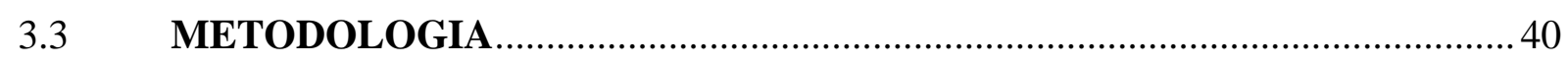


4 RESULTADOS E ANÁLISE DAS PESQUISAS …................................... 42

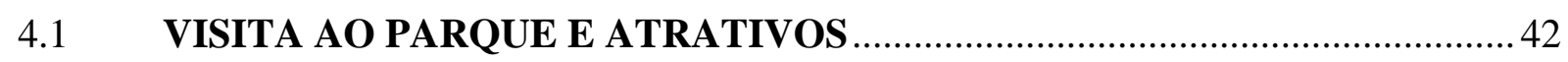

4.2 O PLANO DE USO PÚBLICO DO PARQUE NACIONAL DA CHAPADA

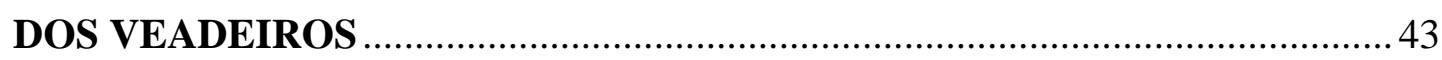

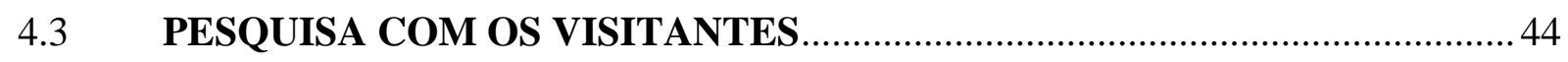

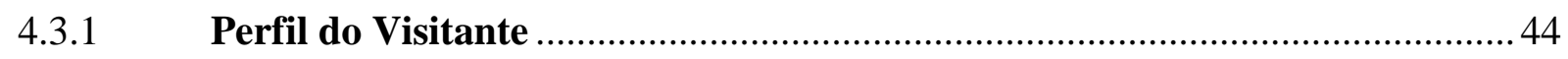

4.3.2 Informações sobre a Visita ao Parque Nacional da Chapada dos Veadeiros 48

4.3.3 Atividades e Serviços no Distrito de São Jorge ............................................... 49

4.4 PESQUISA COM OPERADORAS E AGÊNCIAS DE TURISMO ................... 51

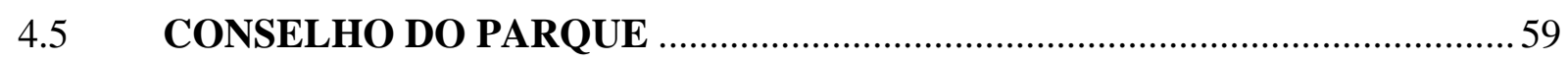

4.6 ENTREVISTA COM CHEFIAS DA UNIDADE DE CONSERVAÇÃO ........... 61

5 CONCLUSÕES E RECOMENDAÇÕES ….............................................. 62

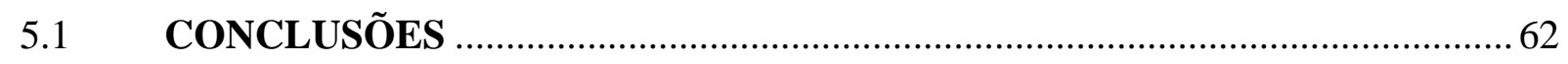

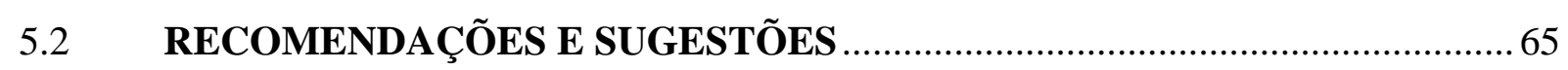

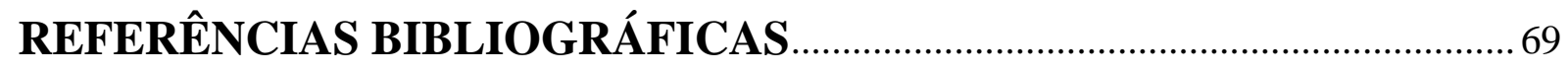

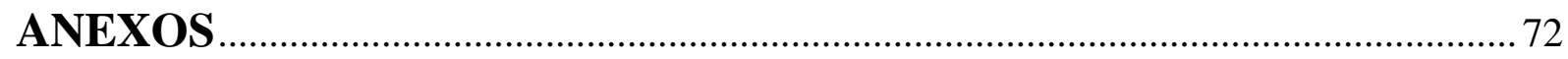




\section{SIGLAS E ABREVIATURAS}

ACTP

ACV-CV

APA

CAT

CET

CONPARQUE

CV

DIREC

EMBRATUR

GTZ

IBDF

IEB

IBAMA

IPHAN

MA

MMA

MICT

MET

OMT

ONG

PAE

PE
- Associação Cidadania, Transparência e Participação

- Associação dos Condutores da Chapada dos Veadeiros

- Área de Proteção Ambiental

- Centro de Atendimento ao Turista

- Centro de Excelência em Turismo

- Conselho Consultivo do Parque

- Centro de Visitantes

- Diretoria de Ecossistemas

- Instituto Brasileiro de Turismo

- Deutsche Gesellschaft für Zusammenarbeit (Agência Alemã de Cooperação Técnica)

- Instituto Brasileiro de Desenvolvimento Florestal

- Instituto de Ecoturismo do Brasil

- Instituto Brasileiro do Meio Ambiente e dos Recursos Naturais Renováveis

- Instituto do Patrimônio Histórico e Artístico Nacional

- Ministério da Agricultura

- Ministério do Meio Ambiente

- Ministério da Indústria, Comercio e Tecnologia.

- Ministério do Esporte e Turismo

- Organização Mundial do Turismo

- Organização não-governamental

- Plano de Ação Emergencial

- Parque Estadual 


\begin{tabular}{|c|c|}
\hline PETAR & - Parque Estadual Turístico do Alto da Ribeira \\
\hline PM & - Plano de Manejo \\
\hline PN & - Parque Nacional \\
\hline PNCV & - Parque Nacional da Chapada dos Veadeiros \\
\hline PNMA & - Programa Nacional do Meio Ambiente \\
\hline PROA VES & - Associação Brasileira para Conservação das Aves \\
\hline PROECOTUR & - Programa de Ecoturismo para a Amazônia Legal \\
\hline PUP & - Plano de Uso Público \\
\hline $\mathbf{R M}$ & - Roteiro Metodológico \\
\hline RPPN & - Reserva Particular do Patrimônio Natural \\
\hline SCA & - Secretaria de Coordenação da Amazônia \\
\hline SEBRAE & - Serviço Brasileiro de Apoio às Micro e Pequenas Empresas \\
\hline SERVITUR & $\begin{array}{l}\text { - Associação de Guias e Prestadores de Serviço em Ecoturismo de Alto } \\
\text { Paraíso }\end{array}$ \\
\hline SIUC & - Sistema de Informações das Unidades de Conservação da Natureza \\
\hline SNUC & - Sistema Nacional de Unidades de Conservação \\
\hline TIES & - The International Ecotourism Society \\
\hline $\mathbf{U C}$ & - Unidade de Conservação \\
\hline UICN & $\begin{array}{l}\text { - União Internacional para a Conservação da Natureza (International } \\
\text { Union for Conservation of Nature and Natural Resources - IUCN) }\end{array}$ \\
\hline UnB & - Universidade de Brasília \\
\hline UNESCO & $\begin{array}{l}\text { - Organização das Nações Unidas para a Educação, a Ciência e a } \\
\text { Cultura. }\end{array}$ \\
\hline
\end{tabular}




\section{RELAÇÃO DE FIGURAS}

1. Localização do PNCV no Território Brasileiro ................................................................ 16

2. Limites do Parque Nacional da Chapada dos Veadeiros ................................................. 17

3. Vista Geral da Área de Visitação e Vegetação Típica do PNCV ......................................2 27

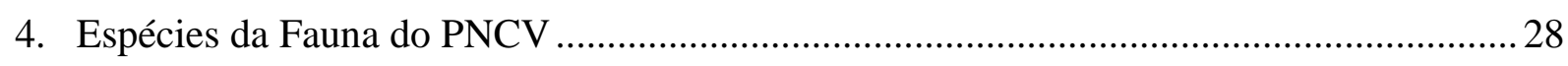

5. Atrativos Abertos ao Público - Salto I, Salto II e Cânion I................................................ 35

6. Atrativos Abertos ao Público - Cânion II................................................................................. 35

7. Atrativos Abertos ao Público - Pedreiras e Cariocas ............................................................ 36

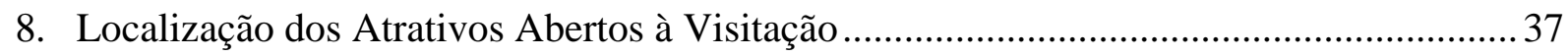

9. Faixa Etária e Nível de Escolaridade de Cem Visitantes no PNCV .................................. 44

10. Rendimento Mensal de Cem Visitantes no PNCV ......................................................... 45

11. Visitas Anteriores e Tempo de Permanência de Cem Visitantes no PNCV ....................... 46

12. Meios de Hospedagem e Atividades Preferidas de Cem Visitantes no PNCV .................. 46

13. Motivos da Visitação de Cem Visitantes no PNCV ……...................................................47

14. Meio pelo qual Cem Visitantes Tomaram Conhecimento do PNCV ............................... 47

15. Equipamentos e Serviços do PNCV Apontados como Prioritários na Área do PNCV

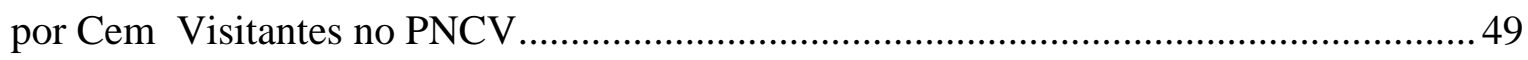

16. Interesse com Relação ao Parque e seu Entorno de Cem Visitantes no PNCV ................50

17. Nível de Exigência Apresentado por Cem Visitantes no PNCV .......................................51

18. Modalidade de Turismo Executado por Seis Operadoras de Ecoturismo ...........................52

19. Origem dos Clientes Atendidos por Seis Operadoras de Ecoturismo ...............................52

20. Fatores que Promoveriam o Aumento do Fluxo de Ecoturismo no PNCV, Apontados

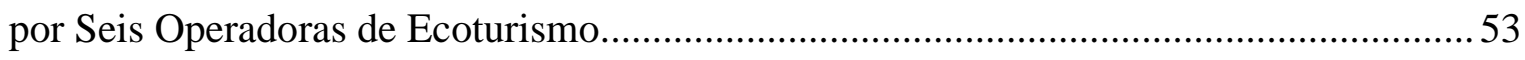

21. Expectativa dos Turistas de Acordo com Seis Operadoras de Ecoturismo ........................54

22. Eficiência dos Meios de Divulgação Apontados por Seis Operadoras ..............................54 


\section{RELAÇÃO DE TABELAS}

1. Distâncias das Cidades de Maior Interesse à Sede do PNCV …........................................ 17

2. Lista dos Doze Parques Nacionais mais Visitados ........................................................... 22

3. Visitantes do PNCV no Período de 1999 a 2002 ................................................................ 22

4. Áreas de Visitação e Distâncias das Trilhas em Uso no PNCV ........................................29

5. Quadro Resumido das Atividades Existentes e Propostas..................................................... 39

6. Outros Destinos Praticados por Seis Operadoras de Ecoturismo .......................................55

7. Avaliação de Serviços e Atividades no PNCV por Seis Operadoras de Ecoturismo ..........57

8. Avaliação de Serviços e Atividades do Distrito de São Jorge por Seis Operadoras de

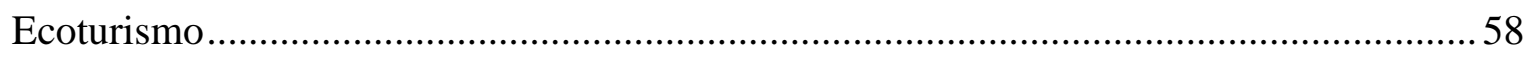




\section{1 - INTRODUÇÃO}

O turismo é atividade de relevante importância para a economia mundial. Apresenta-se atualmente dentre as mais rentáveis e promissoras atividades econômicas, estando em franca expansão no mundo todo.

"Segundo a Organização Mundial de Turismo (OMT), dentre todos os tipos de turismo, o de natureza é o que mais tem se desenvolvido. Enquanto a atividade turística cresce a taxa média anual de $4 \%$, o turismo de natureza cresce a uma taxa de $10 \%$ a $30 \%$ ao ano" (Ceballos-Lascuráin, 1993, apud Kinker, 2002:8).

O ecoturismo vem sendo considerado um dos segmentos que mais cresce na área do turismo e caracteriza-se por visitas a áreas naturais pouco ou nada alteradas, com o objetivo específico de vivenciar, estudar, admirar e desfrutar das belezas cênicas, da flora, da fauna e dos demais recursos naturais, propiciando ainda, a integração com as comunidades locais.

No Brasil, o ecoturismo vem sendo discutido desde os anos 80 , inicialmente com o nome de turismo de natureza ou ecológico. No entanto, a partir da Conferência das Nações Unidas sobre o Meio Ambiente e Desenvolvimento, conhecida como Rio 92, realizada no Rio de Janeiro, o termo ecoturismo consolidou-se como uma das atividades de desenvolvimento sustentável.

Assim é que as Unidades de Conservação (UC) e em especial os Parques Nacionais $(\mathrm{PN})$, se estabelecem como pontos focais para o ecoturismo.

As Unidades de Conservação, incluídas no Sistema Nacional de Unidades de Conservação da Natureza (SNUC), Lei ${ }^{\circ}$ 9.985/2000, dividem-se em dois grupos com características específicas de Proteção Integral e de Uso Sustentável.

Dentre as unidades do grupo de Proteção Integral, figuram os Parques Nacionais, que tem entre seus objetivos o desenvolvimento de atividades de educação e interpretação ambiental, de recreação em contato com a natureza e de turismo ecológico (SNUC, 2000). Assim sendo, são áreas propícias ao ecoturismo, sendo o Parque Nacional da Chapada dos Veadeiros (PNCV), no Estado de Goiás, o objeto do presente estudo.

Segundo Magalhães (2001), o Pólo Chapada dos Veadeiros é composto pelo Parque Nacional da Chapada dos Veadeiros e seu entorno, além das áreas de interesse espeleológico nos Municípios de São Domingos e Posse, ambos no Estado de Goiás.

O PNCV está assentado sobre imensa placa de cristal de quartzo, numa região considerada especial pelos místicos como emanadora de energia sobrenatural. A água de 
muitas de suas cachoeiras e regatos possui cor castanha devido à grande concentração de óxido de ferro e são tão puras como o cristal de rocha que brota de suas terras.

Segundo o Guia de Turismo Ecológico (1999), esse é um dos muitos segredos guardados pela natureza instigante da Chapada, além de seu reconhecido ponto de encontro de místicos e esotéricos de todo o mundo.

Em 1972, a Organização das Nações Unidas para a Educação, a Ciência e a Cultura (UNESCO) criou a Convenção do Patrimônio Mundial, para incentivar a preservação de bens culturais e naturais considerados significativos para a humanidade. É parte do esforço internacional na valorização de bens, que por sua importância para a referência e identidade das nações, possam ser considerados patrimônio de todos os povos. O PNCV foi inscrito pela UNESCO em 16 de dezembro de 2001, como Patrimônio Natural Mundial (Patrimônio Mundial, 2003).

O objetivo geral deste estudo é avaliar a situação do PNCV enquanto produto principal do Pólo de Ecoturismo da Região, tomando-se por base o seu Plano de Uso Público (PUP), sob a ótica dos princípios do ecoturismo, de acordo com o que estabelecem as Diretrizes para uma Política Nacional de Ecoturismo do Governo Federal (EMBRATUR/IBAMA, 1994).

A opção pelo PNCV como área de estudo, teve como base os seguintes aspectos:

1. O PNCV está subordinado administrativamente à Representação do Instituto Brasileiro do Meio Ambiente e dos Recursos Naturais Renováveis (IBAMA) no Estado de Goiás e tecnicamente se encontra vinculado à Diretoria de Ecossistemas (DIREC), do IBAMA em Brasília.

2. É o Parque Nacional mais próximo da Capital do País, excluindo-se o Parque Nacional de Brasília, no Distrito Federal, e sua localização o beneficia mais ainda por poder contar diretamente com o apoio constante da Sede do IBAMA em Brasília.

3. O fato, ainda, de estar localizado próximo de Brasília, de dispor de diversas conotações esotéricas e místicas, além de inúmeras belezas naturais, atrai grande fluxo de visitantes nos finais de semana e feriados, provenientes de Brasília e Goiás principalmente, mas também em menor escala de vários estados brasileiros e do estrangeiro.

4. O PNCV é Unidade privilegiada no contexto das Unidades de Conservação Federais, uma vez que dos 51 Parques Nacionais criados, somente 22 contam com Plano de Manejo atualizado, 08 contam com Plano de Uso Público, e 19 com Plano de Ação Emergencial. O Parque Nacional da Chapada dos Veadeiros conta com todos estes instrumentos de planejamento, e seu Plano de Manejo apesar de ter sido elaborado a menos de cinco anos, se encontra em fase de atualização. 
5. O PNCV conta ainda, com Conselho Consultivo (CONPARQUE), criado desde 2001 por meio da Portaria n 82/2001, e ainda com Regimento Interno, instituído pela Portaria ${ }^{\circ}$ 062/2001.

6. O fato do PNCV ser considerado pelo Instituto Brasileiro de Turismo (EMBRATUR) e pelo IBAMA o foco principal do Pólo de Ecoturismo da Região, foi motivo também que justificou a opção pelo desenvolvimento deste trabalho no Parque.

Todos estes fatores apontam no sentido de se estudar como está sendo aproveitado todo este potencial. Entendendo como potencial os atrativos naturais do Parque, sua localização privilegiada, o fluxo de visitantes e a disponibilidade de tantos instrumentos de planejamento.

Este trabalho está estruturado em cinco capítulos. O primeiro deles inclui a Introdução, que apresenta a visão geral do conteúdo do trabalho, o motivo da escolha do foco do estudo e os objetivos que incluem o porquê e para que se efetuou o mesmo.

O segundo capítulo apresenta a contextualização e a revisão bibliográfica sobre temas focais do estudo, como o ecoturismo, seus conceitos, diretrizes e finalidade; conceituação sobre as Unidades de Conservação e mais especificamente sobre os Parques Nacionais, seus objetivos, instrumentos de Planejamento, sua situação de forma geral e sua interrelação com o ecoturismo; e ainda, sobre Terceirização de serviços e atividades em Unidades de Conservação.

O terceiro capítulo apresenta os materiais e métodos utilizados para alcançar o objetivo do presente estudo. Inicia pela caracterização do PNCV, objeto do estudo, sua história, localização, fauna, flora, acesso, situação geral, instrumentos que o mesmo dispõe para seu manejo e gestão. Apresenta como foi efetuado o estudo, como se procedeu com a pesquisa documental, pesquisa de campo e como foram obtidas, in loco, outras informações.

O quarto capítulo focaliza os resultados das pesquisas, a análise e a discussão dos levantamentos efetuados.

E o quinto e último capítulo apresenta as conclusões do estudo, sugestões e recomendações para adequação do Parque ao ecoturismo, visando de fato inserí-lo como produto ecoturístico do Pólo e da região. 


\section{2 - REVISÃO BIBLIOGRÁFICA}

A seguir são apresentados os temas foco do trabalho, tais como os conceitos de Ecoturismo, Pólos de Ecoturismo, Unidades de Conservação, Parques Nacionais, Planos de Manejo, Plano de Ação Emergencial, Plano de Uso Público, Terceirização e outros.

\section{1 - ECOTURISMO}

O termo ecoturismo surgiu na década de 80 , relacionado a qualquer tipo de viagem especializada ligada à natureza, no entanto até hoje não existe um consenso sobre sua definição, sendo vários os conceitos aplicados ao termo pelos diversos segmentos sociais envolvidos.

A primeira definição conhecida sobre ecoturismo é de Ceballos-Lascuráin em 1988, (apud Kinker, 2002:20) segundo o qual "ecoturismo é a viagem a áreas relativamente preservadas com o objetivo específico de lazer, de estudar ou admirar paisagens, fauna e flora, assim como qualquer manifestação cultural existente".

Ziffer (1989), definiu ecoturismo como:

uma forma de turismo inspirado principalmente pela história natural de uma área, incluindo suas culturas indígenas. O ecoturista visita áreas relativamente não desenvolvidas com um espírito de apreciação, participação e sensitividade. $O$ ecoturista pratica o uso racional dos recursos naturais e da vida silvestre e contribui para as áreas visitadas através da geração de emprego e renda, diretamente beneficiando a conservação do local e o bem-estar dos residentes locais. A visita deve envolver a apreciação e a dedicação dos ecoturistas em assuntos de conservação em geral, e especificamente nas necessidades do local. $O$ ecoturismo também implica em um manejo que aproxima o país ou a região anfitriã ao compromisso em estabelecer e manter os sítios com a participação dos residentes locais, marketing apropriado, estímulo à regulamentação e o uso dos rendimentos das empresas para financiar o manejo de áreas, bem como o desenvolvimento comunitário.

O EMBRATUR (1994) lançou Manual de Ecoturismo, contendo regras e normas sobre o mesmo, além da definição sobre o ecoturismo como:

o turismo desenvolvido em localidades com potencial ecológico, de forma conservacionista, procurando conciliar a exploração turística com o meio ambiente, harmonizando as ações com a natureza, bem como oferecer aos 
turistas um contato íntimo com os recursos naturais e culturais da região, buscando a formação de uma consciência ecológica.

Para Elizabeth Boo (1994) "ecoturismo é viagem na natureza que avança esforços de conservação e de desenvolvimento sustentável".

The International Ecotourism Society (TIES), a maior e mais conhecida organização não-governamental na área, definiu em 1995, ecoturismo como sendo uma "viagem responsável a áreas naturais, visando preservar o meio ambiente e promover o bem estar da população local” (apud Wood, 2002:09).

O Instituto de Ecoturismo do Brasil (IEB), em 1996, conceituou o ecoturismo como "a prática de turismo de lazer, esportivo ou educacional em áreas naturais, que se utiliza de forma sustentável dos patrimônios natural e cultural, incentiva a sua conservação, promove a formação de consciência ambientalista e garante o bem estar das populações envolvidas" (apud Pires, 1998:83).

O conceito de ecoturismo adotado neste trabalho é a definição oficial estabelecida pelo governo federal nas Diretrizes para uma Política Nacional de Ecoturismo qual seja:

um segmento da atividade turística que utiliza, de forma sustentável, o patrimônio natural e cultural, incentiva sua conservação e busca a formação de uma consciência ambientalista através da interpretação do ambiente, promovendo o bem-estar das populações envolvidas (EMBRATUR/IBAMA, 1994).

Estas diretrizes foram estabelecidas em 1994, quando foi constituído grupo interministerial, composto pelo Ministério do Meio Ambiente (MMA), Ministério da Indústria, Comércio e Turismo (MICT), EMBRATUR e o IBAMA, que também incorporou representantes da iniciativa privada e sociedade civil, para elaborar uma política de ecoturismo e definir diretrizes gerais para o desenvolvimento do turismo em ambientes naturais no país.

As prioridades dessas diretrizes voltaram-se para a necessidade de um planejamento integrado e para a articulação institucional em vários níveis incluindo:

* a definição de prioridades para o ecoturismo e o gerenciamento dos atrativos;

* o desenvolvimento da infra-estrutura baseado nas necessidades reais do setor e das áreas exploradas;

* a regulamentação da atividade, incluindo incentivos financeiros e fiscais;

* a educação ambiental de turistas e empresários; e

* o envolvimento das comunidades locais, visando ao desenvolvimento regional e à distribuição da renda gerada pelo ecoturismo. 
De acordo com estas diretrizes, os objetivos das atividades de ecoturismo são:

* Aumento da receita gerada nas diversas áreas conservadas, possibilitando-lhes recursos para a manutenção destas e das comunidades locais;

* Fomento à visita ordenada;

* Preservação dos recursos naturais florísticos, faunísticos e as paisagens cênicas locais; e

* Promoção da utilização racional do patrimônio natural.

Nesse contexto, o ecoturismo apresenta-se como uma opção tecnicamente viável para a manutenção econômica dos recursos naturais, culturais e da comunidade.

Quando comparados às atividades clássicas de desenvolvimento (mineração, agricultura, manufatura de matéria-prima, estradas, hidrelétricas etc.), o ecoturismo e outros serviços provenientes do uso público nas UC apresentam baixíssimo impacto ambiental negativo sobre os recursos e por outro lado impacto positivo na educação ambiental dos visitantes.

Conforme Kinker (2002), o que diferencia o ecoturismo dos outros tipos de turismo de natureza, é que este abrange na sua conceituação a experiência educacional interpretativa, a promoção da conservação da natureza e do desenvolvimento sustentável e a valorização das culturas tradicionais locais, guardando portanto uma afinidade incontestável com unidades de conservação, particularmente com os parques nacionais.

Para que o turismo desenvolvido na natureza possa ser chamado de ecoturismo, é necessário considerar alguns fatores, quais sejam: a conservação do ambiente visitado seja ele natural ou cultural; a conscientização ambiental, tanto do turista como da comunidade receptora; e o desenvolvimento local e regional integrado (Kinker, 2002).

Segundo Paiva (2002), estima-se que o ecoturismo cresceu $10 \%$ ao ano nos últimos cinco anos e que o potencial do mercado seja pelo menos, dez vezes a demanda atualmente atendida.

O ecoturismo, no período de 1988 a 1997, apresentou taxa de crescimento anual de 9\%. As taxas de crescimento do ecoturismo, projetadas para o mundo, superam aquelas do turismo de sol e areia (que não chegará aos 4\%), correspondendo a $6 \%$ para os próximos cinco anos; $7 \%$ para os próximos dez anos e 9\% para os próximos quinze anos, segundo informações da Coordenação do Programa de Desenvolvimento do Ecoturismo para a Amazônia Legal (PROECOTUR) (Soavinski, 2002).

De acordo com Boo (1992), o ecoturismo poderia trazer além de vantagens econômicas para as UC outras quais sejam: 
* a possibilidade de uma maior integração das UC com as comunidades locais e com a sociedade mais ampla;

* a circulação de informação ambiental por meio de programas educativos e da própria visitação;

* o aumento da oferta regional de espaços de recreação e lazer;

* a adesão de visitantes às tarefas de fiscalização;

* a facilidade do controle sobre grupos organizados;

* a divulgação da própria UC e o estabelecimento de "redes" de interessados em sua manutenção.

O EMBRATUR, em conjunto com o IEB, desenvolveu em 1998, o Projeto Pólos de Desenvolvimento de Ecoturismo no Brasil, visando identificar as localidades brasileiras aonde a prática do ecoturismo vinha ocorrendo e assim efetuar o inventário das características, das potencialidades e infra-estruturas de apoio disponíveis.

Assim, segundo esse Projeto, são considerados Pólos Ecoturísticos áreas aonde as atividades ecoturísticas:

* já vêm sendo desenvolvidas com sucesso;

* são promovidas por um número variável de agentes;

* locais com condições naturais especiais, mas poucas atividades devido à falta de infra-estrutura e de organização.

O estabelecimento da prática do ecoturismo em determinado pólo não ocorre por si só, depende também da existência de um pacto de interesses e intenções locais para o estabelecimento de um modelo de gestão e na oferta de produtos aceitáveis pelo público.

Não basta que a área apresente grande potencial representado por seus atrativos naturais e culturais para que seja considerada pólo. É preciso que essas áreas estejam atendidas por facilidades tais como vias de acesso, serviços de hospedagem e alimentação, além da disponibilidade de outras infra-estruturas necessárias como postos de saúde, segurança, combustível, serviços diversos de atendimento e informação ao visitante, e a busca do desenvolvimento local através da gestão dos empreendimentos ecoturísticos (Magalhães, 2001).

Portanto, são necessários planos e projetos relacionados ao setor que venham a pautar a administração pública, de modo a transmitir segurança e perspectiva de continuidade, atraindo empresários e investidores para ali estabelecerem seus negócios. Somente assim se pode possibilitar a consolidação de um pólo ecoturístico. 
Áreas preservadas, em especial Parques Nacionais e Estaduais existentes, tanto na área do pólo como no entorno, são extremamente importantes para a implantação efetiva do ecoturismo. Por suas características ambientais são locais privilegiados para a prática do ecoturismo. No entanto, a inexistência ou a precariedade de infra-estrutura e de pessoal habilitado na maioria dessas unidades impede seu uso adequado (Magalhães, 2001).

A evolução do conceito de Unidade de Conservação relaciona-se com o desenvolvimento da ciência, a destruição da natureza e a busca cada vez maior do resgate de contato com a natureza.

O contato com a natureza tem sido cada vez mais utilizado de forma terapêutica, tanto na medicina formal como nas terapias alternativas, como forma de aliviar, combater e minimizar doenças modernas como o estresse, a tensão, a angústia, as fobias e outras mais.

A visita a áreas protegidas tem desempenhado papel importante na definição de novas UC e suas modalidades. A "febre" ecoturística assistida hoje em dia, do ponto de vista de transformação das relações predatórias do homem com o mundo natural, parece representar algum sinal de mudança nos rumos da degradação acelerada do planeta. Neste ponto, o ecoturismo se encontra estreitamente relacionado ao discurso e às proposições do desenvolvimento sustentável e ao ambientalismo (Serrano, 1993).

Pádua et al. (2001), argumenta que o ecoturismo pode ser considerado como uma das alternativas para conter a degradação ambiental a que as áreas naturais vem sendo submetidas, uma vez que tem o mérito de conjugar o desenvolvimento e a conservação. No entanto a autora comenta que pouquíssimo ou quase nada dos recursos obtidos com o ecoturismo tem sido revertido para as áreas naturais.

Diante desta realidade e da constatação da necessidade de conciliar turismo e conservação, uma vez que os dois elementos estão presentes na conceituação legal dos Parques Nacionais (SNUC), somado ao direito da população ao acesso às riquezas naturais de seu país, é que se entende ser o ecoturismo de fato uma das alternativas para a implantação e implementação efetiva dos Parques Nacionais.

Esse direito da população ao acesso às riquezas naturais de seu país está regulamentado pela nossa Constituição Federal, que em seu artigo 225 rege que "todos tem direito ao meio ambiente ecologicamente equilibrado, bem de uso comum do povo e essencial à sadia qualidade de vida, impondo-se ao Poder Público e à coletividade o dever de defendêlo e preservá-lo para as presentes e futuras gerações”.

Conforme Boo (1992), as Unidades de Conservação sofrem com orçamentos limitados. A visitação permite com que os turistas fiquem mais ambientalmente conscientes, passando assim a ter vontade de participar na conservação das áreas que visitam, e se dispondo a pagar mais para a preservação e manutenção da Unidade de Conservação. 
Portanto, o ecoturismo apresenta-se como atividade por demais promissora e vantajosa para o País, uma vez que se configura como importante alternativa de desenvolvimento econômico sustentável, utilizando racionalmente os recursos naturais, educando os usuários, viabilizando financeiramente as UC, sem comprometer a sua capacidade de renovação e sua conservação (Rocktaeschel, 2003).

O ecoturismo é uma experiência enriquecedora, que contribui para a conservação dos ecossistemas, resgata a interação do homem com os processos naturais, respeitando ao mesmo tempo a integridade cultural das comunidades locais. Essa experiência estabelece uma situação de ganhos diretos e indiretos (culturais, financeiros, mentais, educacionais etc.) para todos os interessados: se a base de recursos naturais é protegida, os benefícios econômicos associados ao uso desses recursos serão sustentáveis (Rocktaeschel, 2003).

Por outro lado, o visitante será capaz de apreciar a experiência natural associada com um meio ambiente bem administrado. Experiência positiva, significa retorno do visitante, propaganda e maior compromisso.

\subsection{UNIDADES DE CONSERVAÇÃO / PARQUES NACIONAIS}

A Lei $n^{\circ}$ 9.985/2000, conceitua por Unidade de Conservação:

o espaço territorial e seus recursos ambientais, incluindo as águas jurisdicionais, com características naturais relevantes, legalmente instituído pelo Poder Público, com objetivos de conservação e limites definidos, sob regime especial de administração, ao qual se aplicam garantias adequadas de proteção (SNUC, 2002).

Conforme citado anteriormente, o SNUC dividiu as unidades de conservação em dois grupos. Dentre o grupo das Unidades de Proteção Integral estão incluídos os PN, que, conforme o SNUC:

tem como objetivo básico a preservação de ecossistemas naturais de grande relevância ecológica e beleza cênica, possibilitando a realização de pesquisas científicas e o desenvolvimento de atividades de educação e interpretação ambiental, de recreação em contato com a natureza e de turismo ecológico.

Os PN além de sua função precípua de proteção da biodiversidade, devem propiciar à população recreação e conhecimento da natureza, pelo contato direto com a mesma. Essa função é denominada genericamente de uso público e implica no conjunto de atividades que podem ser praticadas em uma UC de acordo com sua categoria. Incluem, desde práticas ativas 
e exigentes quanto ao condicionamento físico ou conhecimento da biota, até a simples contemplação da paisagem.

Assim, torna-se necessário um planejamento, que efetue análise da UC, partindo dessas premissas e mantendo as condições de proteção da natureza que lhe são inerentes. Este tipo de planejamento por meio de uma proposta conjunta é essencial, pois a pressão pela população na busca por lazer nas UC vem aumentando gradativamente e as iniciativas isoladas, atendendo de imediato essa demanda, levam a problemas complexos de operação e mal aproveitamento de seu potencial.

Os PN, como estabelecido no SNUC, comportam a visitação pública com fins recreativos, educacionais e voltados ao turismo ecológico, sujeitos às normas e restrições estabelecidas no Plano de Manejo (PM) da unidade, de acordo com as normas estabelecidas pelo órgão responsável pela sua Administração, e àquelas previstas em regulamento.

Segundo o SNUC, Plano de Manejo é :

o documento técnico mediante o qual, com fundamento nos objetivos gerais de uma unidade de conservação, se estabelece o seu zoneamento e as normas que devem presidir o uso da área e o manejo de seus recursos naturais, inclusive a implantação das estruturas físicas necessárias à gestão da unidade.

O PM é um instrumento de planejamento que é elaborado contando com a participação, em momentos específicos, de representantes da comunidade, organizações nãogovernamentais (ONG), universidades, pesquisadores, entidades representativas de vários segmentos da sociedade etc., ou seja, entidades públicas e privadas.

O Zoneamento, conforme a Lei 9.985/2000, entende-se por “definição de setores ou zonas em uma unidade de conservação com objetivos de manejo e normas específicas, com o propósito de proporcionar os meios e as condições para que todos os objetivos da unidade possam ser alcançadas de forma harmônica e eficaz".

O Plano de Ação Emergencial (PAE), é um instrumento de planejamento e gestão das UC de uso indireto (atualmente pelo SNUC de Proteção Integral), sob a responsabilidade do IBAMA/DIREC. O PAE estabelece ações emergenciais e prioritárias, objetivando a resolução no prazo de três anos, de situações críticas existentes, de modo a assegurar a proteção de seus recursos naturais e o manejo da unidade.

O PAE foi criado em 1993, como instrumento transitório, até que o PM da Unidade fosse atualizado ou elaborado, visando principalmente a aplicação de recursos do Programa Nacional do Meio Ambiente (PNMA). Quando da elaboração do Roteiro Metodológico para o Planejamento de Unidades de Conservação de Uso Indireto em 1997, o PAE foi incorporado 
pelo mesmo dentro da Fase I, passando a não mais ser elaborado separadamente e com o nome de PAE.

O Plano de Uso Público (PUP), é o instrumento que identifica as atividades, voltadas ao uso do público pelo visitante, dimensionando e estabelecendo as regras do funcionamento da Unidade e ainda indicando quais atividades podem ser implementadas diretamente pela administração da UC ou por serviços terceirizados, tanto na implantação como na operacionalização.

Quando da elaboração do novo Roteiro Metodológico de Planejamento em 2002, o PUP que vinha sendo elaborado separadamente como um dos Programas de Manejo, foi incorporado, passando a fazer parte integral do Plano de Manejo.

Roteiro Metodológico de Planejamento (RM), é o documento que estabelece os procedimentos gerais para a elaboração dos diferentes estágios de planejamento das Unidades de Conservação. Tem como objetivo a sistematização e a uniformização no tratamento dos dados.

O Decreto $n^{\circ} 4.340$ de 22.08.2002, que regulamentou o SNUC, em seu Capítulo IV, artigo 14, estabelece que deverão ser elaborados Roteiros Metodológicos básicos para elaboração dos Planos de Manejo das diferentes categorias de unidades de conservação.

O IBAMA/DIREC em cumprimento ao Decreto acima citado, elaborou no final do exercício de 2002, RM direcionado para os Parques Nacionais, Reservas Biológicas e Estações Ecológicas, que vem sendo utilizado desde então no planejamento dos mesmos (IBAMA, 2002).

O primeiro Parque Nacional Brasileiro do Itatiaia, no Rio de Janeiro, foi criado em 1937, seguido pelos Parques Nacionais da Serra dos Órgãos - RJ e do Iguaçu - PR, em 1939. Hoje o Brasil conta com 51 Parques Nacionais criados, no entanto apenas 26 deles estão abertos ao público.

Os PN são porções de território que abrigam biodiversidade ímpar, além de grandes belezas cênicas e potencialmente são, sem sombra de dúvidas, áreas irradiadoras de desenvolvimento sustentável através do ecoturismo.

No entanto hoje, a maioria dos Parques não dispõe de infra-estrutura e pessoal suficientes para garantir o bem estar, segurança, apoio aos visitantes e a proteção dos recursos naturais. Disso resulta o pequeno fluxo ou a ausência de visitantes, a impossibilidade de geração de renda e outros benefícios para as UC e para as comunidades locais. Além do mais as UC falham em um dos seus objetivos principais que é a educação ambiental para os visitantes, gerando assim pouquíssimos benefícios para o Parque, para a população local e, de uma forma geral, para o meio ambiente, uma vez que sua visitação propiciará uma maior conscientização e educação ambiental para os visitantes (Rocktaeschel, 2003). 
Rocktaeschel (2003) pondera que a carência de pessoal e de recursos financeiros não permite que os Parques cumpram plenamente sua missão. Assim, o ecoturismo apresenta-se como uma das formas para viabilizar objetivamente os Parques Nacionais Brasileiros e transformá-los em verdadeiros destinos ecoturísticos.

Os Parques, de forma geral, sofrem grande pressão por parte da sociedade no sentido do seu uso público. Até então a visitação nos Parques tem sido mais voltada para o lazer e a recreação. Não há, na maior parte dos casos, um programa efetivo de educação e conscientização ou mesmo envolvimento comunitário e estratégias de captação de recursos para viabilização econômica dos mesmos.

Kinker (2002), argumenta que o ecoturismo pode ser uma solução ao relacionar benefícios econômicos diretos com a conservação, além de proporcionar maior visibilidade das UC para a sociedade, estimulada pela possibilidade de recreação e educação.

Assim é que o ecoturismo surge como instrumento apropriado aos Parques Nacionais, como forma de transformação efetiva de simples turismo de lazer e recreação, em turismo que se sustenta econômica e ambientalmente, na medida em que utiliza de forma adequada recursos naturais e culturais, no sentido de contribuir para sua conservação, na busca de despertar o respeito pela natureza por meio do contato direto com o ambiente natural (Rocktaeschel, 2003).

O conceito de Desenvolvimento Sustentável está em construção, e para fins deste trabalho assumimos a definição do Relatório Brundtland, de 1987, da Comissão Mundial sobre Meio Ambiente e Desenvolvimento, entendido como "processo de mudança em que o uso de recursos, a direção dos investimentos, a orientação do desenvolvimento tecnológico e as mudanças institucionais concretizam o potencial de atendimento das necessidades humanas do presente e do futuro" (Agenda 21, 1992).

\section{3 - TERCEIRIZAÇÃO EM UNIDADES DE CONSERVAÇÃO}

Entende-se por terceirização a prática de repassar a terceiros, a execução de atividades e serviços não essenciais ou atividades meio da empresa ou entidade, compreendendo-se para este fim como atividade meio, aquela que não representa o objetivo primordial da mesma, configurando-se como um serviço ou atividade necessária, porém não essencial.

Este conceito de terceirização em unidades de conservação vem sendo utilizado pelo IBAMA e outros órgãos ambientais públicos. Foi oficializado pelo IBAMA, em seu Guia do Chefe das UC, através do documento intitulado Marco Conceitual para Terceirização de Atividades e Serviços em Unidades de Conservação Federais (Rocktaeschel, 1999). 
Partiu-se do pressuposto que é necessário dotar as unidades de conservação de infraestrutura mínima para atendimento ao visitante de forma geral, como parte das responsabilidades do órgão ambiental competente em disponibilizar a mesma, mas não necessariamente em executar as atividades previstas. $O$ setor privado se apresenta mais bem equipado e capacitado para a execução de tais atividades.

A renovação e a melhoria da infra-estrutura de atendimento ao visitante, por meio de investimentos de capital privado, representam a fórmula de financiamento mais adequada, frente à inexistência de recursos públicos suficientes, para a conservação dos ecossistemas englobados pela UC (Rocktaeschel, 1999).

No caso das UC, a pressão pelo uso das áreas específicas de acesso ao visitante, no sentido de dotar essas áreas de condições e infra-estrutura adequadas, capazes de atender com segurança e qualidade aos anseios da população, é cada vez mais presente.

Considerando-se que a principal missão das Unidades é preservar e conservar os recursos naturais e a biodiversidade, nada mais lógico do que terceirizar a exploração dos demais serviços.

A atenção da demanda turística volta-se, cada vez mais, para as áreas protegidas do país, buscando oportunidades da prática do ecoturismo. Alguns Parques já dispõem de atividades recreativas como campismo, caminhadas, banhos, piqueniques e contemplação de belezas cênicas, sempre integradas à natureza. Elevam-se, assim, a importância e a oportunidade da utilização das atividades recreativas como incentivo à interpretação e à educação ambiental (Rocktaeschel, 2003).

No entanto, para atender a este público crescente torna-se necessário que as UC disponham de infra-estrutura mínima e serviços de vigilância, limpeza, lanchonetes, atividades recreativas variadas, entre outros.

Uma das opções para cobrir o déficit de pessoal, recursos e infra-estrutura tem sido o sistema de delegação de serviço via terceirização. Lança-se mão, por exemplo, de mecanismos como as concessões administrativas para a exploração de serviços. Algumas atividades podem e devem ser efetuadas por particulares, que além de deterem a capacidade operacional e técnica, possuem condições e experiência para oferecer melhor qualidade de serviço (Rocktaeschel, 1999).

Os Parques Nacionais devem promover, através do uso de terceirizações, facilidades e serviços comerciais necessários ao uso, lazer e recreação dos visitantes em suas dependências. Hoje, alguns Parques Nacionais trabalham com o sistema de concessões e outros tipos de terceirizações para a cobrança de ingressos, portaria, vigilância, limpeza, lanchonetes, restaurantes, passeios recreativos terrestres, marítimos, fluviais, teleféricos e lojas de suvenires. 
Objetiva-se, com a terceirização, desenvolver eficazes parcerias com a iniciativa privada, utilizando-se, em alguns casos, os investimentos de capital privado. Deve-se oferecer garantias para estes investimentos, adotando prazos adequados, que assegurem o retorno do capital investido e a suficiente amortização dos bens e equipamentos empregados, numa fórmula que ofereça vantagens para ambas as partes (Rocktaeschel, 1999).

Através de tais formas contratuais, supera-se a crônica e notória falta de recursos públicos com que se debate a Administração Pública no atendimento às obrigações assumidas, levando à frente e vendo efetivamente concluídos empreendimentos que correspondem aos interesses da coletividade. Em vez de serem remunerados com recursos governamentais, os contratados não somente se auto-remuneram, através da cobrança de tarifas aos usuários e da exploração de fontes alternativas e paralelas de recursos, como ainda oferecem às Unidades o pagamento pela exploração dos serviços (Rocktaeschel, 2003).

A utilização desta concepção de terceirização de serviços e/ou atividades reverterá em inúmeros benefícios para a sociedade. Entre as vantagens estão o melhor aproveitamento do potencial de visitação dos Parques, geração de emprego para as comunidades do entorno, redução dos gastos públicos e aumento da arrecadação do Governo. Como resultado, melhoram as condições para a manutenção, pesquisa, educação e preservação das Unidades, e ainda a melhora da imagem da UC, dando maior visibilidade à mesma.

Assim, amenizam-se problemas de carência de recursos humanos e financeiros com que as UC se deparam, inclusive para suas atividades básicas de manejo, fiscalização, educação e conservação do meio ambiente (Rocktaeschel, 1999).

O boom do ecoturismo, utilizando principalmente as UC como foco de suas atividades, mostrou a grande carência e a necessidade de investimentos para a viabilização desses serviços. Faz-se portanto necessário dotar as UC de condições adequadas ao ecoturismo, para que os visitantes possam usufruir de suas belezas cênicas, conviver com a natureza, e mais que isto, se tornarem aliados do governo na preservação do meio ambiente. 


\section{3 - MATERIAL E MÉTODOS}

\section{1 - DESCRIÇÃO DA ÁREA DE ESTUDO}

\subsection{1 - Aspectos gerais do Parque Nacional da Chapada dos Veadeiros (PNCV)}

\subsubsection{1- Informações Gerais sobre a Unidade}

O PNCV, é uma Unidade de Conservação de Proteção Integral, sob administração do IBAMA, estando administrativamente subordinado à Gerência Executiva do IBAMA em Goiás e tecnicamente à sua Diretoria de Ecossistemas (DIREC).

Dentre os instrumentos de planejamento e manejo existentes para administração de Parques Nacionais, o PNCV conta com um PAE de 1995, um PM elaborado de 1998 e um PUP de 2000.

O PNCV é aberto à visitação de terça-feira a domingo e as entradas são permitidas entre 8 e $12 \mathrm{hs}$ e a saída até as 17hs. Só é permitida a entrada de visitantes com acompanhamento de condutores, os quais cobram oficialmente uma diária de $\mathrm{R} \$ 30,00$ para grupos de até 10 visitantes ou $\mathrm{R} \$ 5,00$ por pessoa. O ingresso no Parque é de $\mathrm{R} \$ 3,00$ por pessoa, cobrado na portaria e recolhido aos cofres do IBAMA.

Os condutores que acompanham os visitantes no Parque são, em sua maioria, antigos moradores do Distrito de São Jorge e do Município de Alto Paraíso de Goiás, ex-garimpeiros, que foram treinados pelo IBAMA, ONG e outras entidades e que hoje estão organizados por meio de associações de condutores e por meio de acordo com o IBAMA efetuam a condução do visitante nas áreas permitidas do PNCV.

O Parque conta com um número de seis servidores ao todo para administração, gerenciamento e manejo do mesmo, sendo um de nível superior e quatro de nível médio.

\subsubsection{2 - Localização, Limites e Acessos}

O PNCV, localiza-se no Planalto Central Brasileiro, na Mesorregião do Norte Goiano, nos Municípios de Alto Paraíso de Goiás, Cavalcante, Terezina de Goiás e Colinas do Sul, e situa-se a aproximadamente $252 \mathrm{~km}$ de Brasília e $485 \mathrm{~km}$ de Goiânia. A localização do PNCV no Território Brasileiro pode ser vista na Figura 1. 


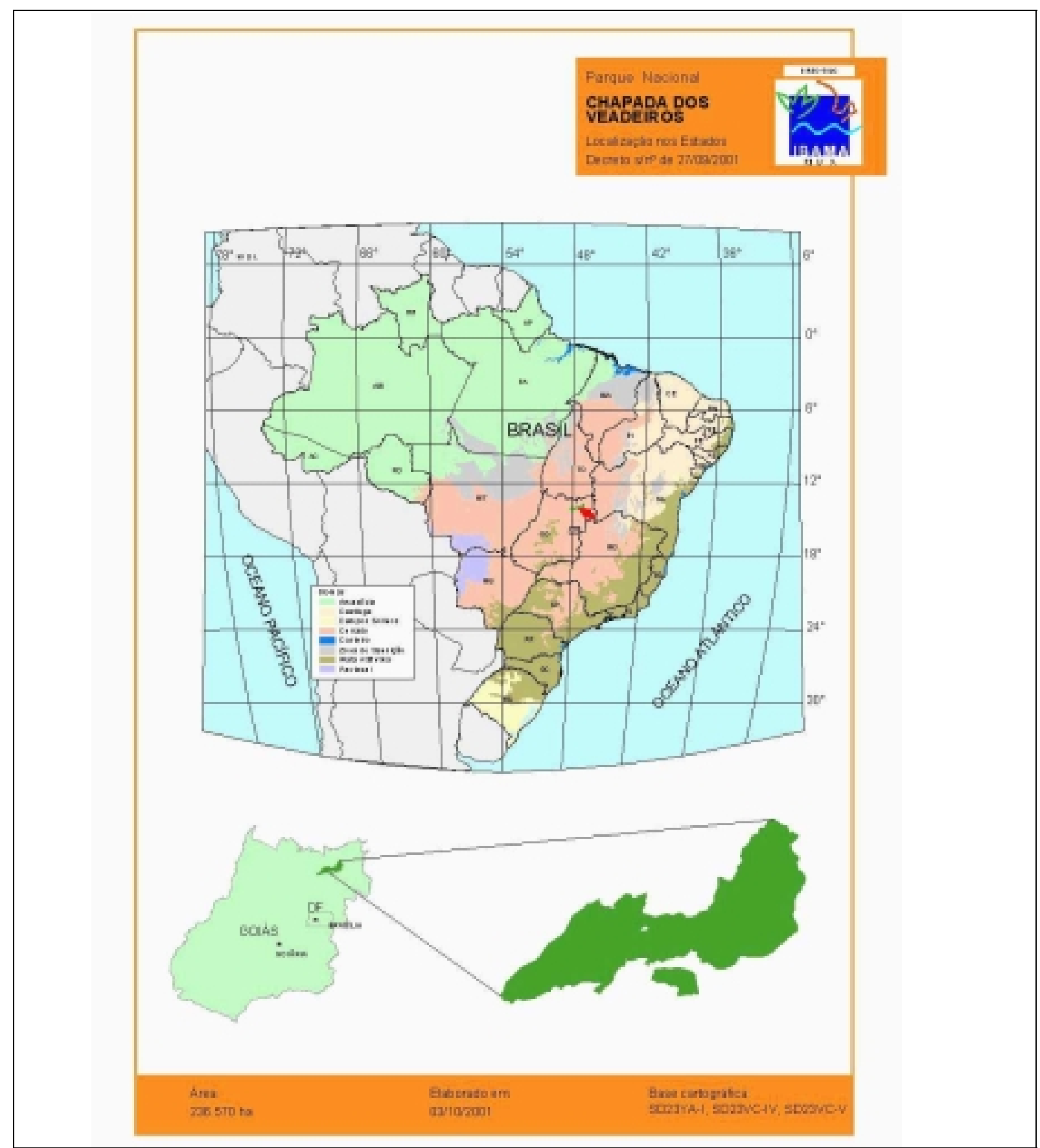

Figura 1 - Localização do PNCV no Território Brasileiro

Fonte: SIUC/IBAMA, 2001

O acesso ao PNCV é feito pela BR-020, saindo de Brasília em direção a Sobradinho e Planaltina, até seu entrocamento com a GO-118, seguindo por $220 \mathrm{~km}$ pela GO-118 em direção a Alto Paraíso; daí toma-se a esquerda pela GO-327 por mais $28 \mathrm{~km}$ em estrada de terra, chegando ao Distrito de São Jorge, portal de entrada do Parque.

Saindo de Goiânia, o trajeto é feito pela BR-060 em direção à Brasília, seguindo então todo o trajeto anteriormente descrito. A distância do PNCV às principais cidades da região onde este está inserido, pode ser vista na Tabela 1. 
Tabela 1 - Distâncias das Cidades de Maior Interesse à Sede do PNCV

\begin{tabular}{l|l}
\hline Cidades & Distância km \\
\hline Alto Paraíso de Goiás & 34 \\
Colinas do Sul & 36 \\
Terezina de Goiás & 101 \\
Cavalcante & 123 \\
São João d'Aliança & 104 \\
Formosa & 233 \\
Brasília & 252 \\
Goiânia & 485 \\
\hline
\end{tabular}

Fonte : Plano de Ação Emergencial (Paes, 1995)

A portaria do Parque encontra-se no Distrito de São Jorge, dentro do Município de Alto Paraíso e dentro da Unidade não existe estacionamento, contando no entanto o mesmo com um estacionamento do lado de fora da Portaria do Parque, a aproximadamente 1.200 metros do Distrito de São Jorge, com capacidade para 30 veículos.

O PNCV possui uma área de cerca de 236,570 ha e seus limites podem ser visto na Figura 2.

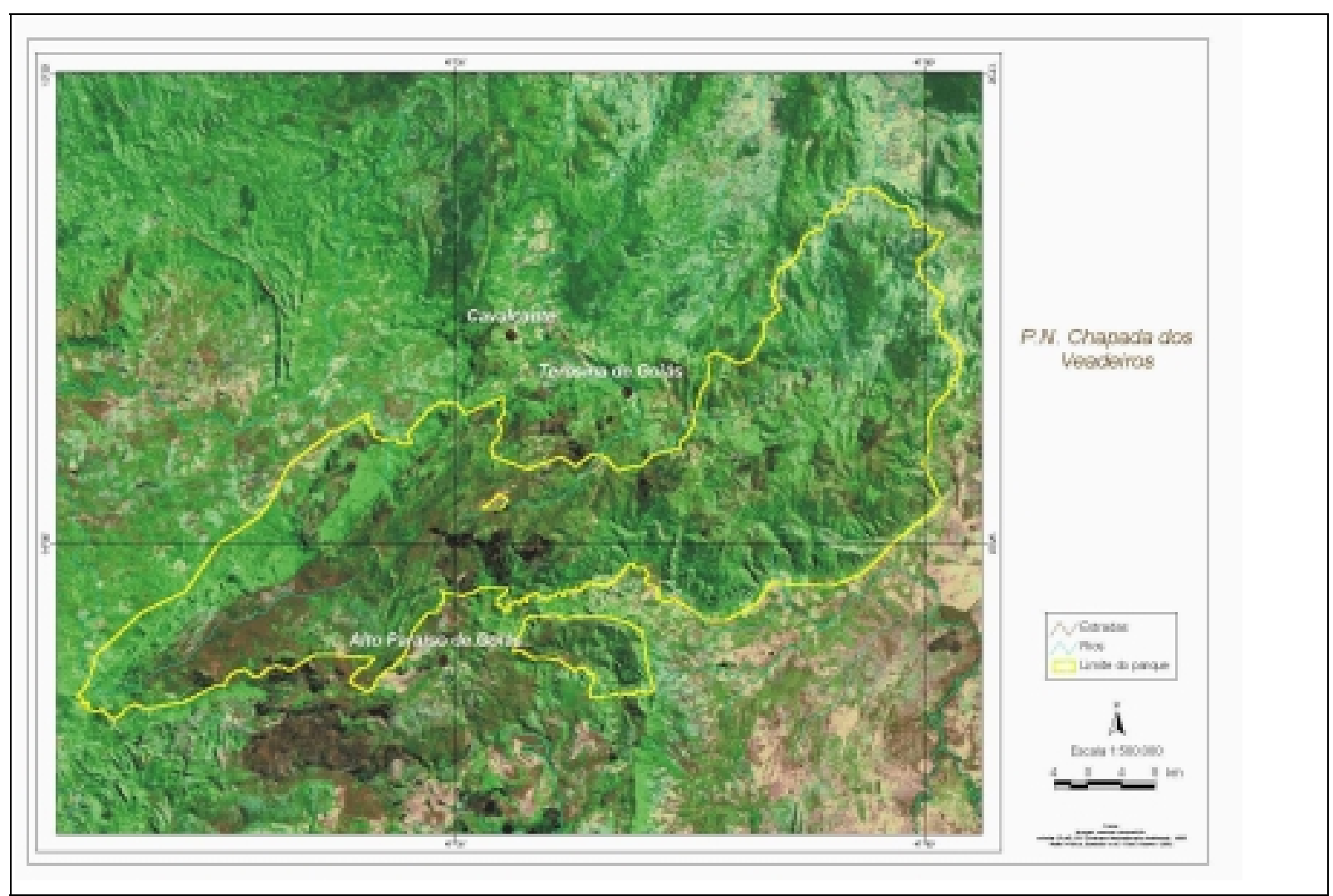

Figura 2 - Limites do Parque Nacional da Chapada dos Veadeiros Fonte: SIUC/IBAMA, 2002 


\subsection{2 - Características Sociais, Econômicas e Culturais}

\subsubsection{1 - Aspectos Culturais e Históricos}

A Chapada dos Veadeiros é dividida administrativamente pelos Municípios de Alto Paraíso de Goiás ao centro, Cavalcante e Terezina de Goiás ao norte, Colinas do Sul a Oeste e São João d'Aliança ao Sul, tomando por base o município de Alto Paraíso.

Conforme o Plano de Ação Emergencial, os principais grupos indígenas presentes na região do Cerrado no Século XVIII eram principalmente pertencentes à família linguística Jê, como por exemplo: Kayapó, Xavante, Karajá, Goyá, Crixá, Akroá, Bororo, Xerente, Apinajé e Timbira. Recentemente sabe-se da existência na região de grupos da família Tupi-Guarani, do tronco Tupi, os Avá-Canoeiro. As lutas travadas resultaram àquele tempo na extinção dos Goyá e Crixá e na redução atual em aldeamentos oficiais, como é o caso dos Avá-Canoeiro, ainda em nomadismo e baixa qualidade vida, mas com espaço em delimitação entre os municípios de Cavalcante e Minaçú (Paes, 1995).

A procura do ouro e de índios para escravização em Goiás, pelos bandeirantes paulistas em 1725, trouxe os primeiros aglomerados urbanos ou arraiais ao local, mas foi somente no Século XX que houve a chegada de um maior contingente de pessoas vindas de todas as partes para o garimpo de ouro, ametista, cristais e manganês. Segundo ainda o PAE, os primeiros registros do Distrito de São Jorge, datam de 1912, passando pelo ciclo iniciado com a busca e a descoberta do minério, depois o auge da produção, seguido do declínio (Paes, 1995).

O atual Distrito de São Jorge, situado no município de Alto Paraíso de Goiás, foi um antigo acampamento cognominado de Garimpão em 1912, sendo renomeado de Povoado ou Vila de São Jorge por iniciativa do garimpeiro Severiano da Silva Pires, que lhe trouxe o padroeiro.

Região de exploração de cristais, com técnicas artesanais, conheceu períodos de maior e menor dificuldade, dependendo da demanda do produto no mercado externo. Os que sobreviveram às crises do garimpo buscaram na agricultura, em tempo de chuva, e no extrativismo de flores do Cerrado e de cristal, durante a seca, uma forma de viver.

A criação do Parque foi proposta pela Fundação Coimbra Bueno, em carta dirigida ao então Presidente da República, Juscelino Kubitscheck de Oliveira, em 04 de outubro de 1960, onde solicitou a criação de um parque nacional na região para preservar as belezas e características ímpares do Cerrado.

O PNCV foi criado por meio do Decreto $\mathrm{n}^{\circ} 49.875$, de 11 de janeiro de 1961 , com uma área de 625.000 hectares, com o nome de Parque do Tocantins. 
Em 1972, por meio do Decreto $\mathrm{n}^{\circ}$ 70.492, de 11 de maio, o Parque em função de grandes pressões dos proprietários e dirigentes políticos dos municípios envolvidos, teve sua área redelimitada para 171.924,54 hectares e seu nome alterado para Parque Nacional da Chapada dos Veadeiros.

As pressões continuaram, principalmente em função do Projeto Agropecuário Alto Paraíso, do então Governador de Goías Ary Valadão, o que levou a uma nova alteração dos limites do Parque por meio do Decreto $\mathrm{n}^{\circ} 86.173$, de 02 de junho de 1981, retificado por erros de impressão pelo Decreto $\mathrm{n}^{\circ}$ 86.596, de 17 de novembro de 1981, que reduziu drasticamente a área do Parque para 60.000 hectares.

O Instituto Brasileiro de Desenvolvimento Florestal (IBDF), órgão responsável à época pelo Parque iniciou então o processo de desapropriação, regularização e delimitação da área. Primeiro por meio do Decreto $\mathrm{n}^{\circ} 87.811$, de 16 de novembro de 1982, depois pelo Decreto $\mathrm{n}^{\circ}$ 99.279, de 06 de junho de 1990, o qual precisou a área como sendo de 65.514, 7259 ha, para efeito de desapropriação. Por meio de Decreto s/n ${ }^{\circ}$ de 2001 , a UC teve sua área expandida, possuindo hoje cerca de 236.570 ha.

O objetivo específico do PNCV, segundo o IBAMA, é proteger os mananciais hídricos da região, asilo natural de uma infinidade de microorganismos e diversas espécies da flora e da fauna. É ainda importante para pesquisa no seu ecossistema típico e para visitação unida à educação ambiental.

Segundo ainda o PAE, a criação do Parque representou para a população do Distrito de São Jorge uma mudança de comportamento. Hábitos culturais vindos de tempos de garimpo, quando eram livres para procurar cristais em toda região, queimando a macega para a catação de flores e retirando palhas de buritis e lenha, foram confrontados com a existência protecionista de um parque nacional (Paes, 1995).

O impacto da criação foi grande, principalmente nos primeiros trinta anos. Atualmente está se buscando soluções conciliatórias de parceria, onde ambos possam obter ganhos diretos. O turismo atraído pelo Parque tem sido o elemento de conciliação e transformação da relação entre a comunidade e a UC.

Com a decadência do garimpo, a construção de Brasília e a criação do Parque, o Distrito de São Jorge transformou-se em área de apoio aos visitantes que se deslocam para o Parque.

Assim, seus moradores que antes se voltavam para atividades agrícolas de subsistência ou extrativismo mineral de cristal e vegetal de flores, estão cada vez mais envolvidos e tem suas principais fontes de renda relacionadas com atividades do ecoturismo como proprietários e/ou prestando serviços em diversas áreas, como condutores de visitantes na área do parque e atrativos no entorno. 
Várias residências foram transformadas em pousadas, restaurantes, lanchonetes e vários terrenos transformados em áreas de acampamento. A população encontrou no turismo seu meio de subsistência.

Verifica-se assim, que direta ou indiretamente todos estão envolvidos com atividades turísticas voltadas para o Parque, o que trouxe uma melhoria nos rendimentos familiares, fato comprovado inclusive pela melhoria das edificações e construção de novas moradias.

O Distrito de São Jorge dispõe atualmente de serviços de hospedagem, alimentação, telefonia, posto de saúde municipal, farmácia, posto policial, escola de $1^{\circ} \mathrm{grau}$, e energia elétrica, que atendem a uma clientela variada, desde estudantes a famílias e pesquisadores. Um dos problemas ainda existentes é o acúmulo do lixo e a falta de água em algumas épocas do ano.

\subsubsection{2 - Situação Fundiária}

Antes da expansão do Parque, em 2001, o mesmo contava com 20\% de sua área, ou seja 12.000 hectares, pertencentes à União. Foi indenizado até o presente momento segundo o PM do PNCV, aproximadamente 20\% da área desapropriada (Pimentel, et al., 1998).

Em 27 de setembro de 2001, durante o evento de comemoração da Semana da Árvore, o presidente Fernando Henrique Cardoso assinou Decreto ampliando a área do parque de 65 mil hectares para 235 mil hectares, com o objetivo de proteger as bacias dos rios Paranã e Preto, que alimentam o Tocantins, e que sofriam degradação ambiental.

Conforme reportagem do Jornal Correio Braziliense de 31 de julho de 2002, esta ampliação causou grande revolta entre os proprietários de terra em municípios como Nova Roma, Cavalcante e São João da Aliança. Estes proprietários fundaram então em novembro a Associação Cidadania Transparência e Participação (ACTP), que conta com aproximadamente cem associados, que reclamam não terem sido ouvidos pelo IBAMA na época da definição dos novos limites do Parque e que os estudos técnicos não foram adequados, alegando ainda que a desapropriação trará desemprego e abandono para a região.

Segundo a ACTP, os mesmos não são contra o aumento da área do Parque, mas da forma como foi definida a nova área, uma vez que o SNUC exige consulta popular e que os mesmos não foram consultados (Faria, 2002).

Quatro associados, donos de grandes áreas, entraram em janeiro de 2002 com pedido de mandado de segurança no Supremo Tribunal Federal contra os efeitos do decreto e saíram vitoriosos em abril. Até o julgamento da liminar, eles não poderão ser desapropriados. 
Segundo ainda a mesma reportagem, o IBAMA alega, que a população foi ouvida por meio do Conselho Consultivo do Parque, que reúne representantes de órgãos públicos e da sociedade, e que ainda foram efetuadas diversas reuniões com prefeitos dos municípios.

Corazolla (2001) em reportagem no Jornal da Biosfera de Alto Paraíso, informa que de fato existe um documento do Conselho Consultivo do Parque, onde é solicitada a ampliação do Parque mas os membros do Conselho não viram, antes do decreto, a proposta a que se refere a aprovação assinada. Existe ainda uma petição de 1992 de várias pessoas, solicitando a criação de uma Estação Ecológica no Pouso Alto, o que não tem nada a ver com o que foi encaminhado pelo Secretário de Biodiversidade e Florestas do MMA, de transformar essa solicitação na base técnica para a ampliação

Segundo este Jornal, parece ter havido uma preocupação centrada na Organização das Nações Unidas para a Educação, a Ciência e a Cultura (UNESCO) em acelerar o processo de ampliação do Parque por parte do MMA, no sentido de possibilitar a inclusão do Parque como Patrimônio Natural da Humanidade, uma vez que um consultor da União Internacional para Conservação da Natureza (UICN), havia sinalizado que uma ampliação do Parque poderia trazer mais um título mundial para a região com sua ampliação.

Assim é que o Parque vive um momento de indefinição frente à já existência de áreas a serem regularizadas dos 65 mil hectares anteriores e agora também sobre as novas áreas incorporadas.

Segundo informações da Direção do Parque e do Setor responsável pela criação de UC da DIREC/IBAMA as dificuldades que se tem encontrado para efetivação da desapropriação e indenização das áreas, dizem respeito à documentação de posse das mesmas por parte dos moradores atuais, que não possuem a documentação legal que comprove sua propriedade.

\subsubsection{3 - Visitação}

Segundo o PM, o asfaltamento da GO-118, a progressiva migração de novos moradores para a região de Alto Paraíso, principalmente após a implantação na década de 80 do Projeto Rumo ao Sol, que tinha como maior meta a busca no Planalto Central de espaço para vivenciar novas formas de tecnologia, alimentação, comportamento e outras posturas de vanguarda, somadas às primeiras divulgações na mídia nacional evocando belezas cênicas e poderes energéticos produzidos pelo cristal e ainda a crescente onda nos meios urbanos de preocupação com a ecologia e meio ambiente provocaram o "boom do ecoturismo", e Brasília principalmente, descobriu o Parque Nacional da Chapada dos Veadeiros (Pimentel, et al., 1998). 
O PNCV em 1998 estava entre os dez PN mais visitados do país, estando agora em $12^{\circ}$ lugar, conforme pode ser observado na Tabela 2 , elaborada com dados obtidos diretamente com a chefia de cada um parques citados.

Tabela 2 - Lista dos Doze Parques Nacionais mais Visitados

\begin{tabular}{c|l|l}
\hline ORDEM & \multicolumn{1}{|c}{ PARQUE } & \multicolumn{1}{|c}{$\mathbf{N}^{\mathbf{0}}$ visitantes (2002) } \\
\hline $\mathbf{0 1}$ & Foz do Iguaçu - PR & 518.163 \\
$\mathbf{0 2}$ & Tijuca - RJ & 497.808 \\
$\mathbf{0 3}$ & Brasília - DF & 256.634 \\
$\mathbf{0 4}$ & Itatiaia - RJ & 98.062 \\
$\mathbf{0 5}$ & Chapada dos Guimarães - MT & 79.600 \\
$\mathbf{0 6}$ & Marinho de Fernando de Noronha - PE & 60.000 \\
$\mathbf{0 7}$ & Serra dos Órgãos - RJ & 47.444 \\
$\mathbf{0 8}$ & Ubajara - CE & 41.867 \\
$\mathbf{0 9}$ & Aparados da Serra - RS & 30.600 \\
$\mathbf{1 0}$ & Serra do Caparaó - MG & 23.260 \\
$\mathbf{1 1}$ & Serra da Canastra - MG & 22.576 \\
$\mathbf{1 2}$ & Chapada dos Veadeiros GO & 20.843 \\
\hline
\end{tabular}

Fonte: Informações Obtidas Diretamente com a Chefia de cada Parque, via Telefone e e-mail em 21.03.03

Os períodos de maior afluência de visitantes ao PNCV coincidem com a estação da seca, com destaque para o mês de julho em função das férias escolares, os feriados prolongados como Semana Santa e Carnaval e ainda de uma forma geral os finais de semana, com grande público de Brasília, Goiás e São Paulo. O número de visitação no Parque tem aumentado nos últimos dois anos, conforme demonstrado na Tabela 3.

Tabela 3 - Visitantes do PNCV no Período de 1999 a 2002

\begin{tabular}{c|c|c|c}
\hline $\mathbf{1 9 9 9}$ & $\mathbf{2 0 0 0}$ & $\mathbf{2 0 0 1}$ & $\mathbf{2 0 0 2}$ \\
\hline 8.875 & 7.927 & 16.480 & 20.843 \\
\hline
\end{tabular}

Fonte : IBAMA/PNCV/Coordenação de Uso Público - fev. 2003

\subsection{3 - Caracterização Biofísica do PNCV}

Toda caracterização biofísica, geológica, hidrográfica, de solos, de fauna e de flora, foram coletadas do Plano de Ação Emergencial e do Plano de Manejo do PNCV (Paes, 1995; Pimentel et al., 1998). 


\subsubsection{1 - Clima}

Segundo a classificação de Köppen, o clima dominante na região Centro-oeste é tropical semi-úmido, tipo Aw. Este é caracterizado por duas estações bem definidas com um verão quente e chuvoso, entre os meses de outubro a abril e um inverno frio e seco, entre os meses de maio até meados de outubro. A pluviosidade média anual situa-se entre $1.500 \mathrm{e}$ $1.750 \mathrm{~mm}$ anuais (Paes, 1995).

Estima-se que as temperaturas médias anuais fiquem em torno dos $24^{\circ}$ a $26^{\circ} \mathrm{C}$. As máximas térmicas ocorrem durante os meses de setembro a outubro, ficando a máxima absoluta entre os $40^{\circ}$ a $42^{\circ} \mathrm{C}$. Durante o inverno, principalmente entre os meses de junho a julho, quando ocorre um menor índice de incidência solar, verificam-se as temperaturas mais baixas, ficando a mínima absoluta entre os $4^{\circ}$ a $8^{\circ} \mathrm{C}$ (Paes, 1995).

\subsubsection{2 - Geologia e Geomorfologia}

Segundo o Projeto RADAMBRASIL (1982) a chapada dos Veadeiros está localizada geomorfologicamente no Domínio de Planaltos em Estruturas Dobradas, na região do Planalto Central Goiano e no Complexo Montanhoso Veadeiros - Araí.

Os Planaltos reproduzem feições de dobramentos realçados pela erosão, entalhados por sulcos estruturais e traduzidos em escarpas cristais assimétricos, barras justapostas truncadas por superfícies de aplainamento, situadas entre 800 e $1.400 \mathrm{~m}$.

A altimetria da região varia de 400 a $1676 \mathrm{~m}$, ocorrendo os pontos mais elevados na chapada dos Veadeiros (serra do Pouso Alto, $1676 \mathrm{~m}$ ), ressaltados por residuais das áreas aplainadas dos topos como a serra de Santana, que serve de divisor das bacias dos rios Montes Claros e das Almas. Nestes topos, onde a superfície esteja parcialmente desnudada, afloram rochas quartzíticas intensamente cisalhadas.

Trata-se de uma região que é formada, durante e após a fragmentação do continente Gonduana, no Período Cretáceo a cerca de 135 milhões de anos atrás. O aparecimento do Grupo de rochas Araí deve-se ao processo de formação e evolução de sequências vulcanossedimentares, tendo sido estes sedimentos deformados durante o soerguimento da área, pela epirogênese iniciada no Aptiano e nos períodos sucessivos, Terciário e Quaternário. Tal movimentação originou a desagregação dos filões primários de quartzo com produção de depósitos secundários coluviais, além da metamorfização de rochas com depósitos de sílica pura, nas fraturas dos quartzitos (Paes, 1995).

A região da chapada é interpretada pelo Projeto RADAMBRASIL (1982) como sendo das Formações Traíra e Arraias, do Grupo de rochas Araí, cujos sedimentos originais foram depositados durante o Pré - Cambriano B, entre 1.700 e 1.100 milhões de anos atrás. 
No PAE é citado além disso, que a Chapada é constituída dos Grupos Paranoá e Bambuí, e do Pré-Cambriano “A” (1.100 a 570 m.a) dos Grupos Araí e Araxá, que estão assentadas sobre rochas magmatitognáissicas e diatexíticas, do Pré-Cambriano Indiferenciado, do Complexo Basal (Paes, 1995) .

\subsubsection{3 - Solos}

Segundo o Levantamento dos Recursos Naturais do Projeto RADAMBRASIL (1982), encontram-se na área do Parque, solos Litólicos Álicos Concrecionários e Nãoconcrecionários, entre moderado e fraco, de textura arenosa média em relevo plano com gradientes suave ondulado e ondulado. Em áreas de relevo forte ondulado, montanhoso e escarpado, como a serra de Santana e o morro da Baleia, apresentam pedregosidade, cascalhos e concreções associados também aos afloramentos rochosos. Estão relacionados aos arenitos, filitos e siltitos das diversas formações geológicas da área.

Também observa-se a presença de Latossolo Vermelho - Amarelo álico fraco e moderado, com textura média e argilosa nas áreas de relevo plano e suave ondulado, onde os solos são profundos, não hidromórficos com B latossólico apresentando sequência de horizontes A, B e C. São solos muito porosos, com alto grau de floculação, fortemente bem drenados e morfologicamente ocupam os relevos com declives pouco acentuados. A interação solo - relevo confere-lhes alta resistência à erosão (Paes, 1995).

\subsubsection{4 - Hidrografia / Hidrologia}

A rede hidrográfica do Parque é formada pelas micro-bacias dos rios Preto e dos Couros, além de uma centena de nascentes, oriundas das inúmeras veredas. Estas nascentes alimentam os córregos de médio e pequeno porte, os quais descem das serras do Pouso Alto, Santana, Cobras, Baleia e outras. Pela declividade do terreno e por ser este muitas vezes pedregoso, ocorrem corredeiras, cachoeiras (dentre a mais conhecidas citam-se os Saltos I e II e a das Cariocas) e quedas d'água.

O principal rio que drena a UC é o rio Preto, o qual nasce na serra do Pouso Alto, fora dos limites do Parque, à direta da rodovia GO-118 e desemboca no rio Claro, abaixo de seu limites. Desce desde as nascentes como um córrego e se junta a outros, já dentro do Parque e forma o rio Preto de águas escuras cortando o PNCV no sentido Leste - Oeste. É afluente do rio Tocantins, da bacia Amazônica e tem como principais tributários os córregos Cara Preta, Brumado, Malícia, Buriti do Trilho, Fundão, do Fel, Estiva, dos Ingleses, de Santana e inúmeros outros de menor porte. Nas áreas próximas ao rio e entre este ocorrem os inselberges, como o Peito de Moça e formam-se sete lagoas sucessivas de grande beleza cênica. 
$\mathrm{O}$ rio dos Couros nasce também na serra do Pouso Alto, abaixo do rio Preto e desemboca no rio Tocantizinho, afluente do rio Tocantins, da bacia do Amazonas, correndo no sentido Noroeste e formando o limite natural da UC à Leste. Esse rio nasce fora do Parque, e se torna bastante vulnerável devido à falta de uma proteção específica, além de ser topograficamente a área circundante bastante próxima da Cidade de Alto Paraíso de Goiás (Paes, 1995).

O regime hidrográfico local apresenta aumento do volume de água no verão, devido à concentração das chuvas entre os meses de novembro a março. Com seus córregos, riachos e rios em grande maioria perenes, essa concentração de chuvas de verão causa nos rios o fenômeno chamado de "tromba d'água". A descarga intensa de chuva ocorre nas cabeceiras (cânions e desfiladeiros) dos rios, resulta em grande massa de água que escoa concentrada e em grande velocidade, arrastando tudo em sua passagem.

Esse fenômeno é precedido de um grande ruído, que se assemelha a um "surdo trovão", verifica-se a turbidez das águas e às vezes, a presença de folhas e de galhinhos de plantas. Logo em seguida aparece uma imensa parede de água com cerca de 2 a $3 \mathrm{~m}$. de altura, de grande força destruidora. A violência das águas oferece perigo mesmo em áreas aparentemente tranquilas, onde os veios de água são de pequeno porte.

\subsubsection{5 - Vegetação}

O PNCV fitogeograficamente localiza-se na região do Cerrado, que abrange as áreas do Planalto Central Brasileiro.

O Cerrado (sensu lato) é um tipo de vegetação tropical semidecídua, oligotrófica, com fisionomias variando do arbóreo denso ao gramíneo-lenhoso. É caracterizado, de modo geral, por apresentar árvores de pequeno porte, isoladas ou agrupadas sobre um tapete graminóide. Sua vegetação lenhosa apresenta brotos foliares bem protegidos, cascas grossas e rugosas, corticosas, órgãos de reserva subterrâneos, via de regra profundos (xilopódios) e folhas geralmente desenvolvidas, com estômatos comumente abertos e protegidos por pêlos, constituindo formas de vida adaptada a solos deficientes e aluminizados (Paes, 1995).

A fitofisionomia do Cerrado do Parque apresenta-se como um mosaico que se dá desde os campos rupestres, localizados nas serranias e nos afloramentos rochosos de maior altitude. Segue-se a vegetação tipo cerrado (sensu stricto), onde a encosta diminui sua declividade. O gradiente de vegetação resulta da declividade, da fertilidade do solo e, principalmente, do grau de umidade do solo, que aumenta nas áreas mais baixas, fundos de vales, onde ocorrem campos úmidos, as veredas e as matas de galeria. Nas áreas de campo úmido, cuja topografia é plana, ocorrem veredas adjacentes às florestas de galeria. 
O Parque é composto por áreas de cerrado, cerradão, matas de galeria, matas mesofíticas, campos e veredas. A flora é representada por 1.476 espécies, distribuídas em 579 gêneros e 135 famílias. As famílias mais comuns do PNCV são Leguminosae com 171 espécies, Gramineae 139, Compositae 118, Melastomaceae 69, Euphorbiaceae 64, Rubiaceae 54, Myrtaceae 42, Orchidaceae 39, Malpighiaceae 37 e Cyperaceae com 27 espécies. Desse total de 1.476 espécies, 1.058 são da categoria arbustivo/herbácea e 418 são árvores (Pimentel et al., 1998).

Inúmeras são as espécies existentes e listadas pelos autores, destacando-se a presença de cerca de 50 espécies raras ou endêmicas ou ameaçadas pela destruição de seus ambientes naturais. Alguns exemplos são llex congesta (Aquifoliaceae), Maytenus chapadensis (Celastraceae), Calea irwinii, Eremanthus veadeiroensis, Planaltoa Iychnophoroides, Trichogonia grazielae, Trichogonia grazielae, Trichogonia prancei, Vermonia grearii e V. souzae (Compositae), Leucothoe chapadensis (Ericaceae), Paepalanthus phaeocephalus e Syngonanthus appressus var. chapadensis (Eriocaulaceae), Manihot irwinii (Euphorbiaceae), Chamaechrista altoana, Chamaescrista cavalcantina, Mimosa irwinii e M. venatorum (Leguminosae), Hyptis paradisi e H. tagetifolia (Labiatae), Diplusodon appendiculosus (Lythraceae), Banisteriopsis irwinii e Peixotoa goiana (Malpighiaceae), Miconia irwinii e Lavoisiera ordinata (Melastomataceae), Encyclia chapadensis (Orchidaceae), Podocarpus sellowii, P. brasiliensis (Podocarpaceae), Barbacenia andersonii e B. cylindrica (Velloziaceae) e Xyris goyazensis e X. metallica (Xyrídaceae), dentre outras.

Algumas espécies estão ameaçadas por super-exploração, tais como a arnica (Lynchnophora ericoides, Compositae) e a aroeira (Myracodruon urundeuva, Anacardiaceae).

Ressalta-se ainda a descoberta de várias novidades botânicas, das quais merece destaque especial a descoberta de três táxons novos de gramíneas, isto é, uma espécie nova e dois gêneros novos.

A espécie nova pertence ao gênero Arthropongon Ness e é uma pequena erva de porte delgado, coletada em brejo, logo após a passagem do fogo dentro do PNCV. Um dos gêneros foi denominado Paradisium, em homenagem à cidade de Alto Paraíso. O outro novo gênero à época do PM não foi nomeado.

Foi coletada também uma espécie nova da família Rubiaceae, pertencente ao gênero Borreria, e que deverá se chamar Borreria dimorpha Kirkbride. Além desta foi encontrada ainda uma espécie nova pertencente à família Burseraceae, Tetragastris grossa R. Daly. Na família Leguminosae, duas novas espécies foram descobertas, uma que dever ser chamada de Chamaecrista fulgida e outra Mimosa natalis, além de uma espécie nova de Bauhinia aff. malacotrichoides Cowan e uma espécie nova da familia Araliaceae, no gênero Schefflera. 
Dentre as espécies estudadas, destacam-se algumas mais comumente conhecidas, como o jatobá-do-cerrado, o buriti, os ipês, cedro, aroeira, virola, peroba, landim, angico, pau-brasil-do-interior, babaçu, arnica, mangaba, cagaita, e copaíba; dentre as de uso artesanal principalmente o palipalam-da-serra, o sombrero, o capim-ouro e a pratinha.

A Figura 3, apresenta uma visão geral da área de visitação do Parque Nacional da Chapada dos Veadeiros e de sua vegetação típica.

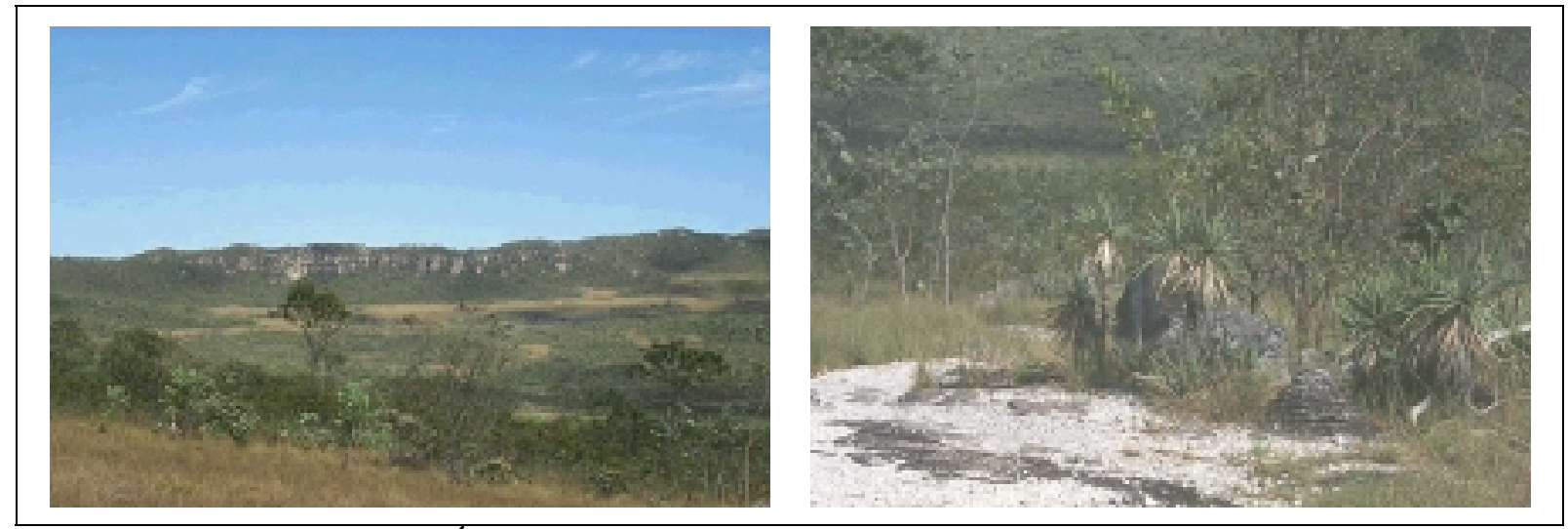

Figura 3 - Vista Geral da Área de Visitação e da Vegetação Típica do PNCV Foto - Rocktaeschel, 2002

\subsubsection{6 - Fauna}

Cerca de 160 espécies de mamíferos têm sido descritas para o Cerrado, sendo 60 morcegos, 40 roedores, 21 carnívoros (como o lobo - guará), 13 marsupiais (como o gambá e a cuica), 11 desdentados (como o tamanduá-bandeira e vários tatus), seis artiodáctilos (como os porcos silvestres e os veados), seis primatas (como o macaco-prego) e um perissodáctilo (como a anta).

Desses destacam-se exemplos como o cervo-do-pantanal, o cachorro-do-matovinagre, a ariranha, a onça-pintada, a suçuarana, a jaguatirica, o tamanduá-bandeira, o tamanduá-de-colete, o veado-campeiro, a anta, o lobo-guará, a raposa-do-campo, o veadocatingueiro, o veado-mateiro, a paca e a capivara (Pimentel et al., 1998).

Várias são as espécies existentes na área do Parque, mas poucas podem ser vistas nas áreas abertas à visitação, considerando principalmente o grande fluxo de pessoas que afastam com o ruído estes animais. Na Figura 4 podemos ver exemplos de espécies de fauna facilmente observados nas trilhas de acesso aos atrativos do PNCV.

No que diz respeito à avifauna, foram estudadas 307 espécies de aves na região, dentre elas se destacam a maria-preta-de-garganta-vermelha, o chopim-azeviche, a cigarra-dobambu, o papa-capim-de-barriga-branca, o chororozinho-bicudo, o pato-mergulhão, o ticotico-mascarado, a ema e o andarilho, dentre outros. 
Com relação à ictiofauna (peixes) foram registradas 49 espécies pertencentes a 11 famílias e 34 espécies de anfíbios anuros (ex. sapos, rãs).

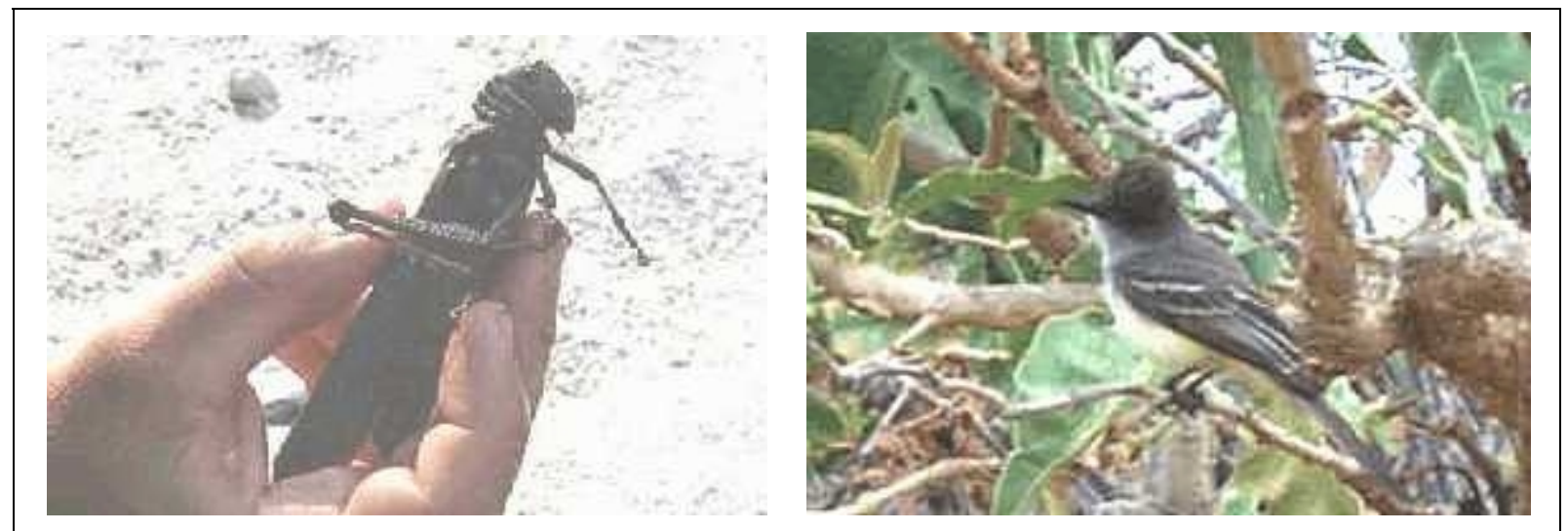

Figura 4 - Espécies da fauna do PNCV

Foto - Rocktaeschel, 2002

\section{2 - INSTRUMENTOS DE MANEJO OU USO DA ÁREA DA UC}

\subsubsection{Plano de Manejo do PNCV}

O Plano de Manejo do Parque Nacional da Chapada dos Veadeiros foi elaborado em 1998, por meio de um convênio com a Associação Brasileira para a Conservação das Aves (PROAVES), com recursos advindos da compensação ambiental das Centrais Elétricas de FURNAS.

Segundo informações do IBAMA, tendo em vista a expansão da área do Parque, o Plano de Manejo está em processo de revisão. Os dados constantes neste estudo, portanto, são os que figuram no PM elaborado em 1998 e aprovado pelo IBAMA (Pimentel, et al., 1998).

O plano de manejo, propôs para o Parque as seguintes zonas :

* zona de Uso Extensivo;

* zona Intangível;

* zona de Recuperação;

* zona de Uso Especial; e

* zona de Uso Intensivo.

Para fins deste estudo, será considerado somente os aspectos do Plano de Manejo, relacionados com as áreas e atividade de Uso Público e Ecoturístico do PNCV. 
Segundo o plano de manejo, na época de sua elaboração, foi realizada pesquisa com os visitantes, não constando no entanto no mesmo o universo desta pesquisa. Foi constatado nesta pesquisa, por ordem de maior importância, os itens que o visitante gostaria de encontrar no Parque, quais sejam :

$1^{\circ}$ sinalização informativa/explicativa;

$2^{\circ}$ folhetos de divulgação;

$3^{\circ}$ exposições no Centro de Visitantes (CV);

$4^{\circ}$ mais trilhas;

$5^{\circ}$ excursões no interior do Parque;

$6^{\circ}$ mais sanitários; e

$7^{\circ}$ mirantes.

Segundo ainda o PM, foi realizada pesquisa com os moradores do Distrito de São Jorge e $87,5 \%$ dos entrevistados acreditam que o PNCV trouxe benefícios, por meio da oportunidade de exploração de atividades comerciais ligadas ao ecoturismo; no entanto, os $12,5 \%$ restantes acham que, apesar das boas oportunidades criadas, o relacionamento da comunidade com o IBAMA é ruim, limitando os benefícios possíveis. De acordo com esta pesquisa, $85 \%$ acham que a exploração do ecoturismo como alternativa à garimpagem contribuiu para o crescimento do Distrito. O PM não identifica no entanto o universo da pesquisa com estes moradores.

O tempo médio de permanência do visitante no Parque é de seis horas e os principais pontos de interesse, capacidade de suporte e suas distâncias desde a portaria de entrada são os apresentados na Tabela 4.

Tabela 4 - Áreas de Visitação e Distâncias das Trilhas em Uso no PNCV

\begin{tabular}{l|l|l|l|l}
\hline ORDEM & Área de Visitação & $\begin{array}{l}\text { Distância do } \\
\text { CV/km }\end{array}$ & $\begin{array}{l}\text { Capacidade de } \\
\text { Suporte } \\
\text { (pessoas/dia) }\end{array}$ & $\begin{array}{l}\text { Tempo médio de } \\
\text { percurso }\end{array}$ \\
\hline $\mathbf{0 1}$ & Saltos I e II & 5,0 & $120 \mathrm{a} 150$ & $2 \mathrm{~h}$ \\
$\mathbf{0 2}$ & Pedreiras & 3,0 & $120 \mathrm{a} 150$ & $1 \mathrm{~h}$ \\
$\mathbf{0 3}$ & Cânion II & 5,5 & 100 & $2 \mathrm{~h}$ \\
$\mathbf{0 4}$ & Cariocas & 5,0 & 100 & $1: 45 \mathrm{~h}$ \\
$\mathbf{0 5}$ & Cânion I & 6,0 & 100 & $2: 15 \mathrm{~h}$ \\
\hline
\end{tabular}

Fonte: Plano de Ação Emergencial - Áreas Abertas a Visitação (Paes, 1995) 
As atividades de lazer normalmente desenvolvidas são as caminhadas, banhos e lanches à beira dos corpos d'água, sendo que atividades como observação de vida silvestre e outros não são efetuados.

O PM não efetuou estudos de capacidade de carga, no entanto recomendou a manutenção da capacidade anteriormente estabelecida no PAE até novos estudos. Ressalte-se no entanto, que o PAE também não apresenta em nenhum momento informações de como chegou a determinação desses limites de capacidade de carga.

O PM indica ainda que, além das áreas permitidas a visitantes ecoturísticos, outras poderão ser estudadas para esta finalidade, com evidentes benefícios para a conservação do Parque, uma vez que a presença de visitantes inibe caçadores, coletadores, garimpeiros e outras formas de invasão da área do Parque.

O plano sugere que se abram trilhas de travessia com pernoite no Parque ou fora dele, aproveitando aspectos culturais (vida de garimpeiro) presentes na UC, tais como :

1. trilha das Fiandeiras, com pernoite em Capela ou dentro do Parque;

2. trilha do Acaba-Saco; e

3. trilha do Brumado ou do Pouso Alto/Catingueiro.

Sugere para visitantes de terceira idade:

1. trilha Sete Lagoas;

2. trilha Rabo da Baleia; e

3. trilha Pouso Alto.

Foi detectada ainda, quando da elaboração do PM, uma insatisfação por parte dos visitantes, com a obrigação de entrada no Parque, acompanhada de condutor, tanto pelo preço, considerado elevado, como pela limitação de sua liberdade dentro do mesmo.

Quando do PM foi realizada oficina de Planejamento, não constando no entanto o universo de participação na mesma. Nesta oficina foi definido o foco de análise como: $\mathrm{O}$ PNCV NÃO ATINGE TODOS OS SEUS OBJETIVOS. Os problemas abordados então foram:

* Conhecimento precário: em função da pesquisa incipiente e da inexistência do monitoramento ambiental, o que demonstra o desconhecimento sobre as inúmeras pesquisas existentes no mesmo. O monitoramento de fato foi constatado não existir pela equipe que elaborou o PM;

* Uso Público inadequado: recreação desordenada, falta de programa de uso público, interpretação e educação ambiental insuficientes. Problemas constatados como de fato procedentes; 
* Integração com área de influência deficiente: também constatado como procedente;

* Manejo do meio ambiente insuficiente: caracterizado pela inexistência de manejo dos recursos e pela insuficiência da proteção;

* Operacionalização inadequada: representada pela regularização fundiária incipiente, pela deficiência nas atividades de administração e manutenção, caracterizados principalmente pela insuficiência de recursos humanos e financeiros.

O PM indicou a permissão de:

* construção de infra-estrutura para atender as atividades de administração, fiscalização, educação e interpretação ambiental;

* implantação de trilhas para observações e interpretação dos recursos naturais do Parque;

* utilização de sinalização adequada para melhor informação e interpretação dos recursos naturais do Parque;

* a abertura da trilha do Carrossel no período entre maio e outubro, com condutores dotados de habilitação específica para este roteiro;

* abertura da trilha do Cruzeiro, também com condutores com habilitação específica em interpretação ambiental;

* uso de transporte especial para deslocamento até as Pedreiras, adequado a visitantes idosos e com menor preparo físico, a ser implantado sob o regime de concessão;

* implantação de sistema de venda de produtos artesanais, locais e institucionais no $\mathrm{CV}$, que deveria funcionar sob forma de concessão;

* implantação de passeios especiais, guiados e interpretados, a serem explorados sob o sistema de concessão.

Ainda sob o ponto de vista de interpretação e educação ambiental são indicadas a implantação de programas específicos para o Parque, exposições e produção de material informativo e sinalização.

No que diz respeito à integração com a área de influência, são indicadas a necessidade de um trabalho contínuo de informação, conscientização e educação junto à população e a participação mais ativa do Parque nas atividades socioculturais da comunidade. 
Quanto ao incentivo a alternativas de desenvolvimento, dentre as atividades e normas propostas, está a participação da informação aos proprietários do entorno sobre ecoturismo, fomentando a criação de áreas particulares para ecoturismo auto-sustentáveis.

\subsubsection{Plano de Uso Público do PNCV}

O PUP, do PNVC, apresenta análise da área de uso público do Parque, inclusive da situação legal e da tercerização dos serviços no mesmo (Leeuwenberg, 2001).

São identificados como pontos principais:

* A necessidade do MMA e do IBAMA de investirem em infra-estrutura, recursos humanos e na manutenção dos equipamentos existentes;

* A necessidade de regulamentação da segurança dos visitantes, solucionando legalmente a responsabilidade do poder público, exigindo qualidade e capacidade mínima para os condutores que atuam na Unidade;

* A necessidade urgente de regularização da situação dos condutores de visitantes dentro do Parque; e

* A necessidade de terceirização para exploração das atividades no PNCV.

As soluções principais indicadas para cada um dos tópicos acima citados são:

1 - pessoal e infra-estrutura: aumento do contingente do parque, atualmente com seis funcionários, para o mínimo de quatorze funcionários e implantação de infraestrutura mínima de atendimento ao visitante. Condições de manutenção dos equipamentos existentes e dos novos a serem construídos e adquiridos.

2 - condutores e segurança do visitante: recomendada a alteração do termo condutor para o uso do termo "Condutor Ambiental", para não se confundir e não conflitar com os guias turísticos registrados pelo EMBRATUR e por ser termo mais condizente com a função exercida.

A necessidade de capacitação e seleção dos condutores com exigências de provas oral e escrita de conhecimento geral e específico, e de primeiros socorros, com reciclagens periódicas.

A regulamentação dos valores máximos a serem cobrados pelos condutores para que não haja exploração dos visitantes em função da obrigatoriedade do acompanhamento de condutor para acesso ao Parque.

Obrigatoriedade de uso de rádio e material de pronto socorro por parte dos condutores; de pessoal especializado nas atividades de rapel e canionismo e ainda de 
investimentos na infra-estrutura para permitir maior segurança para o visitante quando em percurso nas trilhas.

3 - terceirização de atividades e serviços: como forma de viabilizar atividades diversas para os visitantes. De forma geral o PUP sugere que todas as atividades de uso público sejam terceirizadas.

São levantados, ainda, alguns pontos importantes e urgentes de serem solucionados, tais como:

* a situação de erosão das trilhas e a inexistência de manutenção e monitoramento das mesmas, podendo vir a sofrer grandes erosões, com perigo para os visitantes e altos custos financeiros de recuperação;

* a inexistência de sinalização em toda área do Parque e também de folheteria e comunicação, provocando também grande risco para os visitantes;

* o desinteresse dos visitantes no conhecimento ambiental, provocado possivelmente pela falta de preparação dos mesmos por parte da administração do parque, que não conta com $\mathrm{CV}$, nem material educativo; e

* a utilização por parte dos visitantes de trajes inadequados, que podem trazer riscos de picadas de insetos, alergia pela vegetação, cortes, quedas e picadas de cobra e que não recebem alerta por parte dos funcionários do Parque.

O serviço de guiagem dos visitantes é feito obrigatoriamente por condutores da Associação dos Condutores de Visitantes da Chapada dos Veadeiros (ACV-CV) e da Associação de Guias e Prestadores de Serviço em Ecoturismo de Alto Paraíso de Goiás (SERVITUR). Esta atividade já existente desde de 1991, no entanto segundo o PUP, nunca foi formalizada entre as Associações e o IBAMA, sendo a autorização para esta condução apenas um compromisso verbal.

No PUP é levantada ainda a necessidade definição por parte do IBAMA em quais atividades e quais condições o visitante deverá ser obrigado a entrar acompanhado por condutor, apresentando três possibilidades :

* Trilhas auto- guiadas, sem acompanhamento;

* Trilhas com risco ou complicações que exigem acompanhamento profissional; e

* Visitantes associados a grupos registrados de esportes radicais que poderiam entrar nessas trilhas sem acompanhamento, desde que a empresa esportiva seja reconhecida pelo IBAMA e que a mesma seja responsável pelo comportamento dos seus membros dentro do parque.

Em função dos estudos e dados levantados, o PUP apresenta propostas de atividades a serem mantidas ou alteradas no que diz respeito ao uso público. Para fins do presente 
trabalho, serão consideradas somente as atividades propostas na área do PNCV, uma vez que existem propostas para seu entorno.

São apresentadas no Plano as atividades já em operação e proposta novas atividades e intervenções nas já existentes para o uso público do Parque e foram, segundo o PUP, discutidas e aprovadas pelo IBAMA, que são :

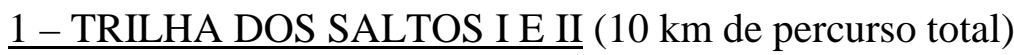

O Salto II é uma cachoeira de $120 \mathrm{~m}$, que só pode ser vista de cima. Acima da cachoeira, até o Salto I, está o rio com grande quantidade de pedras e um poço natural na base do Salto I. Antes da chegada no mirante do Salto II, há um panorama fascinante do vale do rio Preto, abaixo do Salto II, acessível para contemplação e meditação. A trilha passa ainda por diversos atributos naturais, formados pelos diferentes tipos de habitats, como campo rupestre, mata ciliar, campo limpo úmido, campo sujo rupestre e mata seca. O primeiro trecho dessa trilha passa por área abandona de garimpo onde fatos históricos da região podem ser informados. São valas profundas deixadas após a retirada de cristais. Não há sinalização ou equipamentos de segurança ao redor destas valas. É área que deve ser alertada com antecedência aos visitantes. Os Saltos podem ser vistos conforme fotos na Figura 5.

É indicada a construção de guarda-corpo e corrimão nos mirantes do Salto II . Sugere ainda que seja aberta nova trilha, de retorno do Salto I até um ponto de descanso, que deverá ser construído em local sombreado (200 m após o final da estrada administrativa), com bancos, mesas, e lixeiras. Placas interpretativas devem ser colocadas ao longo da trilha visando sua identificação. Deverão ser colocadas também placas de advertência sobre os perigos e as valas locais e contra o uso de drogas, álcool e fogo.

Esta trilha já está em operação e é apropriada para todas as idades com um mínimo de condição física, excluindo terceira idade e crianças com menos de oito anos. O tempo de permanência no local é geralmente de uma a duas horas.

\section{2 - TRILHA DO CÂNION I (11 km de percurso total)}

O Cânion I é de menor tamanho que o II, com menos atrativos, sendo no entanto habitat do pato-mergulhão motivo pelo qual é sugerida a interdição da trilha até o estudo do uso do local pelo pato-mergulhão. Foto do Cânion I pode ser vista na Figura 5.

Esta trilha já está em operação e é apropriada para pesquisadores com autorização prévia e formal do IBAMA. 


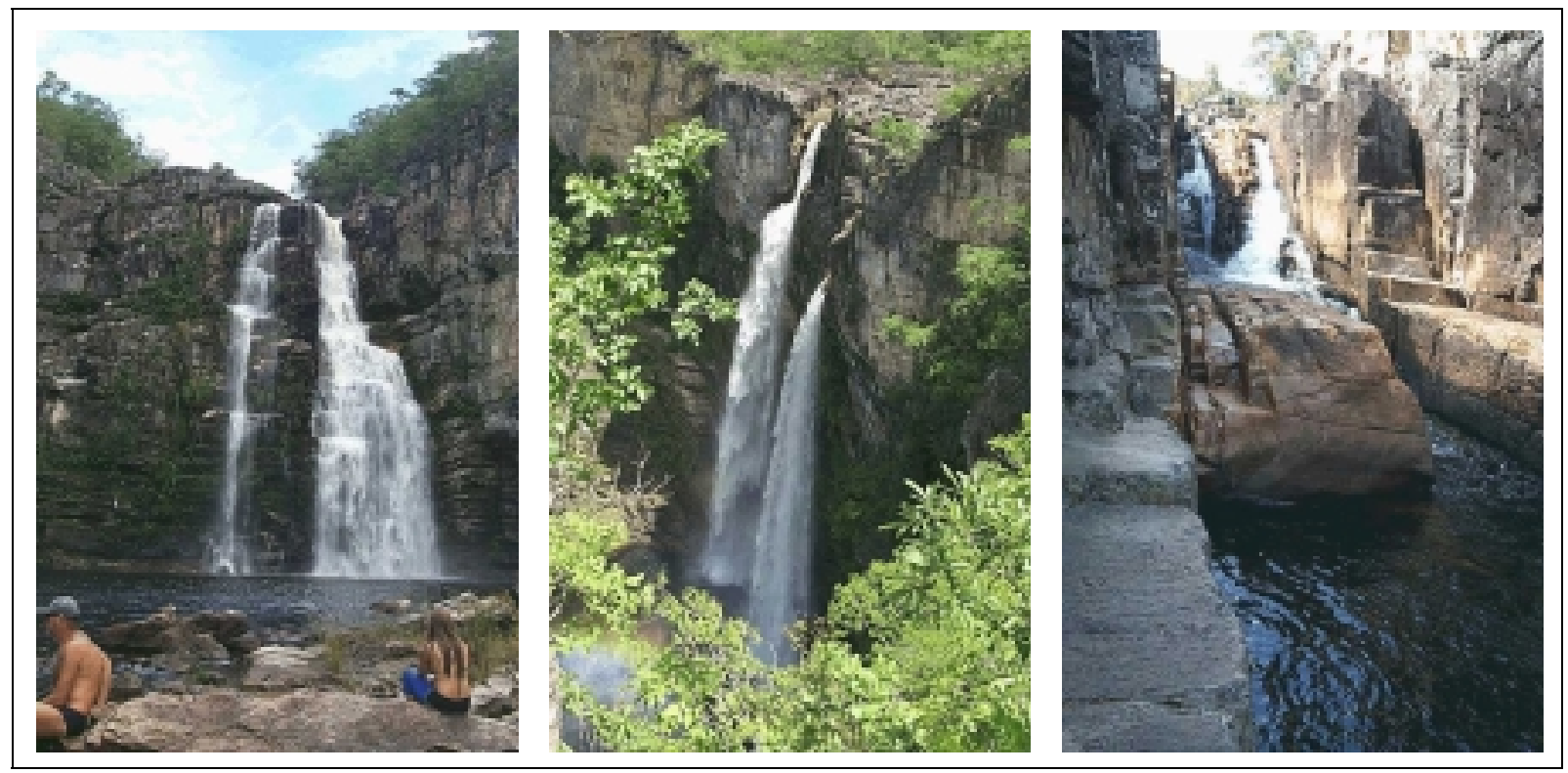

Figura 5 - Atrativos Abertos ao Público: Salto I (esquerda), Salto II (centro) e Cânion I (direita)

Foto - Rocktaeschel, 2002

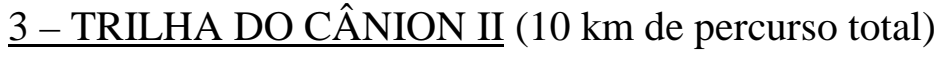

O Cânion II encontra-se cerca de $4 \mathrm{~km}$ acima das Pedreiras e tem o rio Preto passando pelo funil do cânion e chegando num grande poço, de onde continua normalmente por área bastante rochosa, conforme foto apresentada na Figura 6.

Existe a necessidade de implantação de ponte, plataforma, guarda-corpo, escadas e local de descanso. Além disto, é necessário a colocação de placas interpretativas e de advertência dos perigos existentes.

Esta trilha já está em operação e é apropriada para todas as idades com um mínimo de condição física, excluindo terceira idade e crianças menores de dez anos.

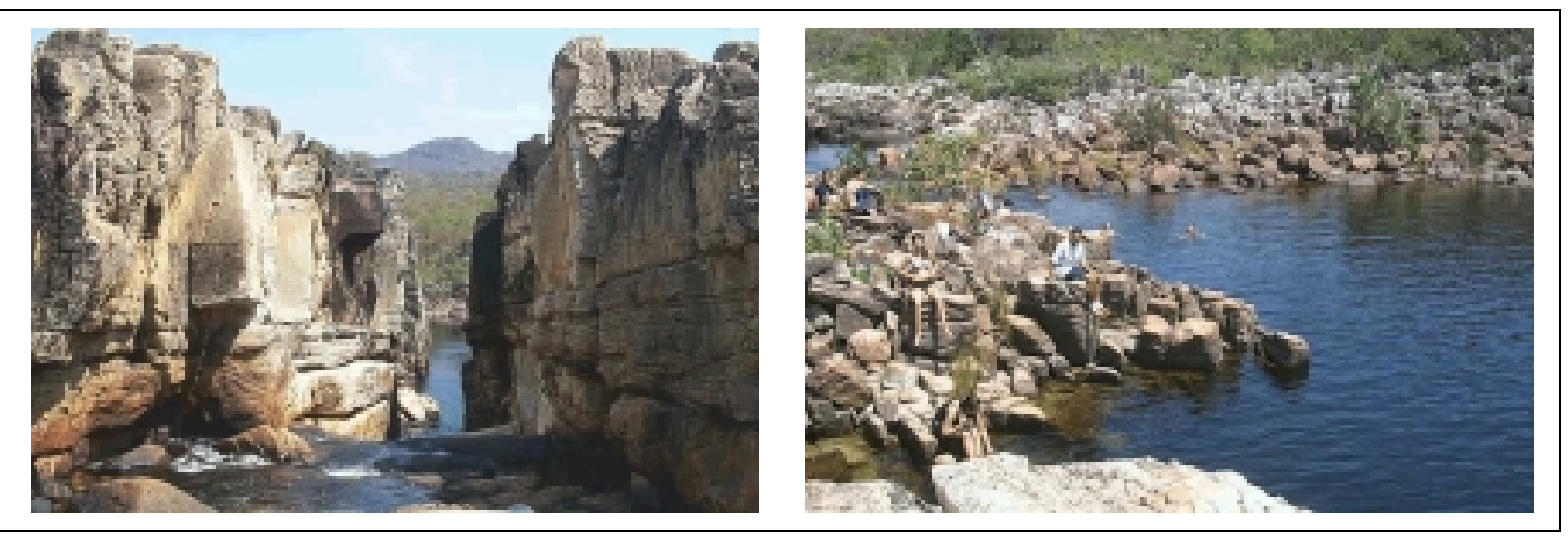

FIGURA 6 - Atrativos Abertos ao Público: Cânion II Foto - Rocktaeschel, 2002 


\section{4 - TRILHA DAS PEDREIRAS $(7 \mathrm{~km}$ de percurso total)}

As Pedreiras se encontram em local plano e aberto. Consistem em diversas pequenas cachoeiras do rio Preto, com piscinas naturais rasas. É uma área bastante espaçosa e foto do local pode ser vista na Figura 7.

Sugere-se a implantação de local de descanso com sombra (na beira de uma matinha que se encontra a $120 \mathrm{~m}$ do rio), com mesas e bancos e ainda a instalação de lanchonete.

Esta trilha já está em operação e é apropriada para todas as idades com um mínimo de condição física, excluindo terceira idade e crianças menores de dez anos, salvo se houver transporte para os mesmos. A condução deve ser guiada com no máximo vinte grupos por dia, cada um com no máximo dez pessoas.

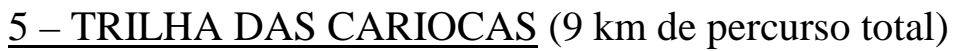

A área conhecida por As Cariocas encontra-se mais acima do rio Preto, cerca de $2 \mathrm{~km}$ acima das Pedreiras. A cachoeira tem múltiplas quedas d'água, um poço grande e pedras extensas no lado esquerdo do rio. É um local onde as pessoas costumam ficar entre uma e cinco horas tomando banho e mergulhando, conforme foto do local apresentada na Figura 7.

É sugerida a implantação de trilha alternativa para descida/subida, visando resolver o problema de superlotação em um ponto que constitui estrangulamento. A implantação de corrimão na descida e de placas de advertência sobre os perigos existentes também devem ser implementados.

Esta trilha já está em operação, sendo apropriada para todas as idades com um mínimo de condição física, excluindo terceira idade e crianças menores de dez anos.

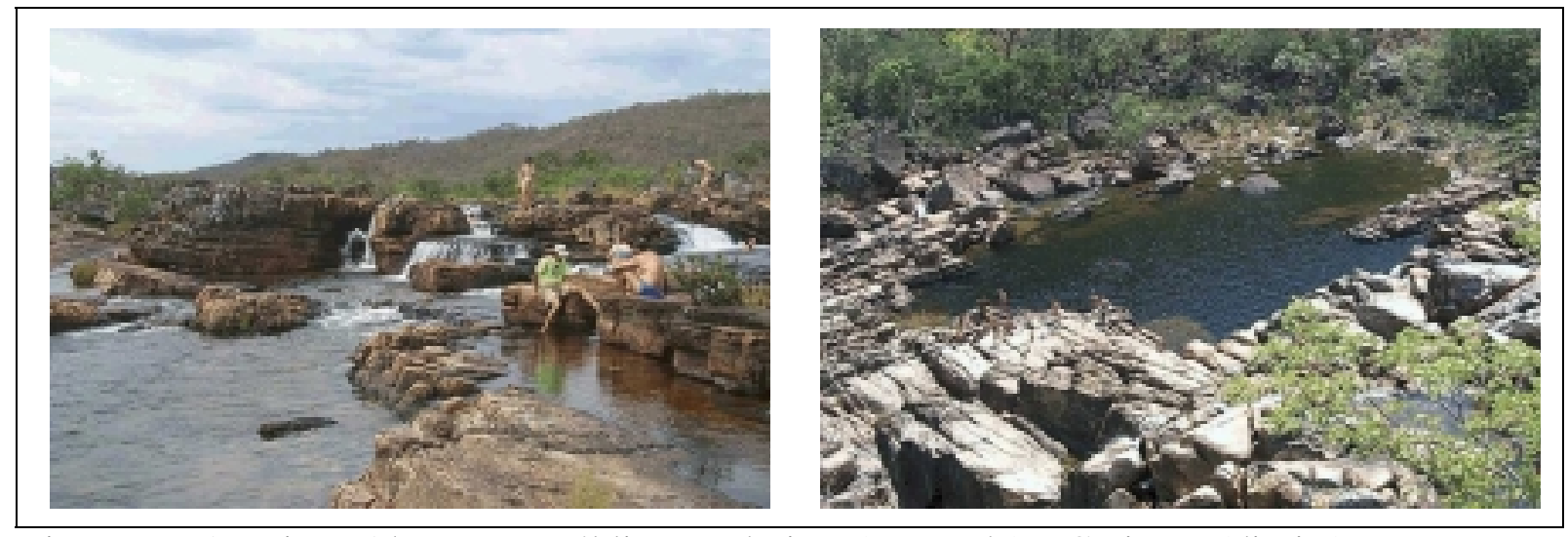

Figura 7 - Atrativos Abertos ao Público: Pedreiras (esquerda) e Cariocas (direita) Foto - Rocktaeschel, 2002

De acordo com o PUP, todas as trilhas acima citadas, devem ser guiadas e terceirizadas.(Leeuwenberg, 2001) 


\section{6 - CENTRO DE VISITANTES - CV}

Sugerida sua implantação ainda no PM, no entanto não se encontra ativado. No que diz respeito ao Centro de Visitantes, é sugerida a reforma do atual, para servir de sede da administração do parque e proposta a construção de um novo CV em outro local, distante da portaria atual, em forma circular com telhado segmentado igual a um cristal e com sala aberta para exposição de filmes e palestras. Segundo o PUP o CV deve ser gerenciado pelo IBAMA.

O IBAMA conta já com Projeto Museográfico pronto para ser implementado no Centro de Visitantes do PNCV.

A Figura 8 abaixo, apresenta um croqui com as áreas de uso público abertas e em visitação no PNCV.

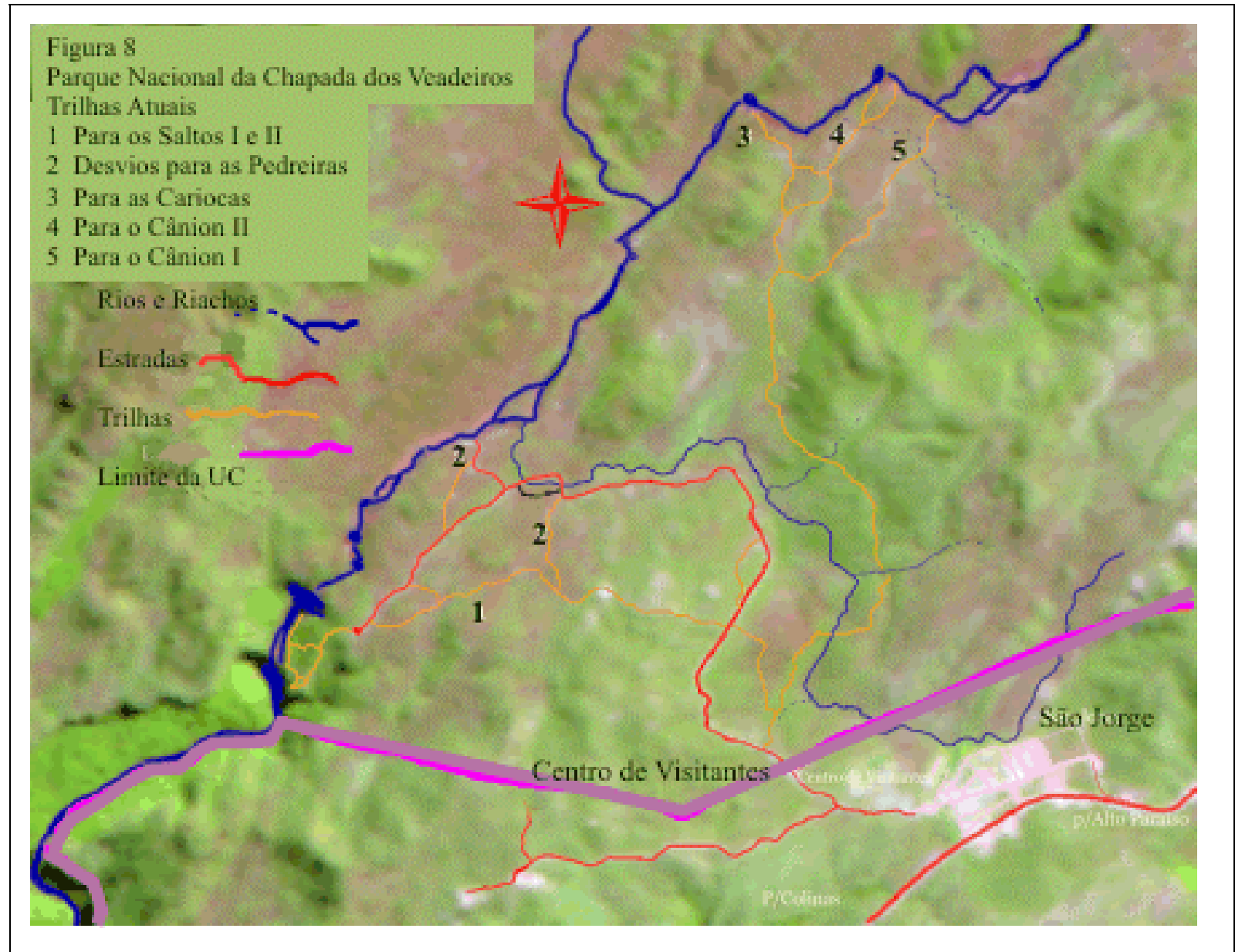

Figura 8 - Localização dos Atrativos Abertos à Visitação

Fonte: PUP - PNCV/IBAMA (Leeuwenberg, 2001)

Foram ainda indicadas no PUP, trilhas e atividades a serem implantadas e disponibilizadas ao Público, algumas, reforçando a indicação anterior do PM, quais:

1. TRILHA SÃO JORGE - CAPELA (32 km de percurso de total, 2 dias);

2. TRILHA DO CARROSSEL (9 $\mathrm{km}$ de percurso total);

3. TRILHA RABO DE BALEIA (3 km de percurso total); 
4. TRILHA DO CRUZEIRO (6 $\mathrm{km}$ de percurso total);

5. TRILHA RODOVIARINHA (1.900 $\mathrm{m}$ de percurso total);

6. TRANSPORTE PARA PEDREIRAS PARA TERCEIRA IDADE (7 km de percurso total) - PROPOSTA NOVA;

7. MIRANTE CARROSSEL - PROPOSTA NOVA;

8. MIRANTE SERRA DO RIO PRETO - PROPOSTA NOVA;

9. TRILHA DAS COBRAS (cerca de 15-18 km o percurso total) - PROPOSTA NOVA;

10. TRILHA BURITI-MIRIM (cerca de $20 \mathrm{~km}$ o percurso total) - PROPOSTA NOVA;

11. TRILHA FAZENDA CONCEIÇÃO (fora do parque) - PROPOSTA NOVA;

12. MIRANTE CAPÃO GROSSO (500 m o percurso total) - PROPOSTA NOVA;

13. CICLOVIA SÃO MIGUEL - RIACHO FUNDO (40-45 $\mathrm{km}$ o percurso total / $50 \%$ fora do parque) - PROPOSTA NOVA;

14. TRILHA FAZENDA RENASCER ATÉ PONTE DE PEDRA (cerca de $7 \mathrm{~km} \mathrm{o}$ percurso total/ fora do parque) - PROPOSTA NOVA;

15. PONTE DE PEDRA (canionismo/limite do parque) - PROPOSTA NOVA; e

16. EVENTO CICLISTA ANUAL “TOUR DOS VEADEIROS" (entorno do parque) - PROPOSTA NOVA.

O PUP apresenta ainda um quadro comparativo sobre as vantagens e desvantagens de operacionalização terceirizada ou não no Parque, tendo sido considerado que a terceirização é aplicável para todas as atividades existentes/propostas, exceto nos casos onde haja necessidade direta de gerenciamento pelo IBAMA, como nas atividades auto-guiadas e Centro de Visitantes.

Não foi efetuado pelo PUP nenhum estudo de capacidade de carga, tendo sido indicada a necessidade de sua elaboração por profissionais da área, a serem realizados tanto para as atividades em operação como para as novas propostas. Sugere-se, para tal, a avaliação da vulnerabilidade do solo para erosão e a superfície de rocha ou terra firme disponível por pessoa, utilizando parâmetros de acordo com o tipo de solo onde o percurso passa e considerando a segurança do visitante.

É recomendada a adoção pelo IBAMA da coordenação do monitoramento das atividades e o estudo de viabilidade econômica para comercialização no CV de produtos locais, utilizando a imagem do parque e das diversas trilhas.

É constatado o pouco preparo dos moradores do Distrito de São Jorge para atendimento ao visitante e registrada a necessidade de capacitação para os mesmos, visando o melhor atendimento e o desenvolvimento de artesanato e culinária local de qualidade. 
Foi identificada em todo trabalho a ausência de sinalização e identidade visual, necessários urgentemente ao Parque, bem como guias e manuais de avifauna, vegetação, mamíferos, répteis e anfíbios da região.

Na Tabela 5 a seguir, é apresentado de forma resumida, as atividades existentes e as novas propostas apresentadas no PUP e alguns dados julgados relevantes sobre os mesmos, para fins de visitação.

Tabela 5 - Quadro Resumido das Atividades Existentes e Propostas

\begin{tabular}{|c|c|c|c|c|}
\hline Ordem & Local & $\begin{array}{l}\text { Capac. Suporte } \\
\text { pessoas/dia }\end{array}$ & $\begin{array}{l}\text { Acesso de } \\
\text { idosos }\end{array}$ & Situação \\
\hline 01 & Trilha Salto I e II & $140-150$ & Não & Aberta \\
\hline 02 & Trilha Pedreiras & $160-180$ & Sim & Aberta \\
\hline 03 & Trilha Cariocas & $160-180$ & Não & Aberta \\
\hline 04 & Trilha Cânion II & $120-130$ & Não & Aberta \\
\hline 05 & Trilha Cânion I & --- & ---- & Fechar \\
\hline 06 & Transporte Pedreiras & ----- & Sim & Nova \\
\hline 07 & Trilha S. Jorge / Capela & 28 & ----- & Nova \\
\hline 08 & Trilha Carrossel & 24 & $\mid----$ & Nova \\
\hline 09 & Trilha Rabo da Baleia & $30-40$ & Sim & Nova \\
\hline 10 & Trilha Cruzeiro & 50 & Sim & Nova \\
\hline 11 & Trilha Rodoviarinha & --- & Sim & Nova \\
\hline 12 & Mirante Carrossel & 72 & Sim & Nova \\
\hline 13 & Mirante Serra do Rio Preto & 50 & Sim & Nova \\
\hline 14 & Trilha das Cobras & 66 & ---- & Nova \\
\hline 15 & Trilha Buriti - Mirim & 66 & --- & Nova \\
\hline 16 & Trilha Faz. Conceição & --- & --- & Nova \\
\hline 17 & Mirante Capão Grosso & $\mid---$ & Sim & Nova \\
\hline 18 & Ciclovia S. Miguel / Parque & 35 & Sim & Nova \\
\hline 19 & Trilha Faz.Renacer / P.Pedra & --- & --- & Nova \\
\hline 20 & Ponte de Pedra & --- & -- & Nova \\
\hline 21 & Tour dos Veadeiros & ---- & -- & Nova \\
\hline 22 & Centro de Visitantes & --- & Sim & Fechado \\
\hline $23 *$ & Rapel Salto I & ---- & -- & Nova \\
\hline $24 *$ & Rapel Salto II & --- & -- & Nova \\
\hline
\end{tabular}

Fonte: PUP- PNCV (Leeuwenberg, 2001) (* atividades novas propostas) 


\section{3 - METODOLOGIA}

Para o presente estudo, foi em primeiro lugar feita a identificação, o levantamento e a leitura de material referencial sobre ecoturismo, unidades de conservação e terceirização de serviços em áreas protegidas.

O levantamento bibliográfico sobre o Parque Nacional da Chapada dos Veadeiros foi realizado na Biblioteca da UnB, no Centro de Informações Ambientais do IBAMA e informações gerais na Internet complementou a pesquisa.

Vencida esta fase, foram efetuadas pesquisas aos instrumentos de planejamento elaborados para o Parque, como seu Plano de Manejo, Plano de Ação Emergencial e finalmente seu Plano de Uso Público.

Foram efetuadas, ainda, visitas à unidade responsável pela gerência técnica do Parque, qual seja, a Diretoria de Ecossistemas do IBAMA por meio de suas áreas de Coordenação Geral de Unidades de Conservação e Coordenação Geral de Regularização Fundiária, e consultas ao Sistema de Informações das UC (SIUC).

Foram efetuadas pesquisas também em revistas de ecoturismo, turismo e jornais tanto nacionais como no jornal local da Chapada, intitulado Jornal da Biosfera.

A visita ao local foi a próxima etapa de estudo. Foram efetuadas 04 viagens de campo, em finais de semana, com entrevistas e aplicação de formulários de pesquisa de perfil de visitante em trilhas dentro do Parque.

Uma das visitas aconteceu em Cavalcante, onde foi realizada reunião dos membros do Conselho Consultivo do Parque (CONPARQUE), oportunidade ímpar de se conhecer melhor a situação atual do Parque, do ponto de vista do seu Conselho.

A pesquisa com visitantes do Parque foi uma das estratégias utilizadas como parte da metodologia do presente estudo. Esta técnica foi utilizada para avaliar a percepção e a opinião dos visitantes sobre o Parque, suas condições e necessidades.

Mediante autorização da Administração da Unidade, foi apresentado o objetivo da pesquisa e entregues aos visitantes os questionários, no Portão do Parque quando da saída dos mesmos, e também nos Saltos I e II, Pedreiras, Cariocas e Cânions.

O questionário foi elaborado contendo duas partes distintas, a primeira com respeito aos dados do entrevistado, ou seja o perfil do visitante e a segunda, contendo informações sobre a visita propriamente dita. No Anexo A é apresentado o modelo do questionário utilizado.

A parte referente ao perfil do visitante consta de nove tópicos com os itens: local de origem, sexo, formação, faixa etária, ocupação principal, nível de escolaridade, estado civil, 
número de filhos e rendimento mensal.

A segunda parte, ou as informações sobre a visita e o Parque, consta de dezesseis tópicos com itens sobre a situação como o visitante viaja, quantas vezes por ano, quantas visitas já efetuou ao parque, tempo de permanência, meio de hospedagem, meio de locomoção, atividades preferidas, motivos da visita, como tomou conhecimento do Parque, opinião sobre as atividades e serviços no Parque e no Distrito de São Jorge, valor gasto no período de permanência, equipamentos e serviços que gostaria de encontrar no Parque; nível de exigência com relação a vários itens ligados ao ecoturismo, levantamento de interesse dos visitantes e sugestões e observações abertas. Foram entregues e preenchidos um total de cem questionários nesta etapa.

Além da pesquisa com visitantes no Parque, foram aplicados questionários com operadoras de turismo via Internet, visando identificar o interesse das mesmas no PNCV, os pontos positivos e maiores entraves para efetivação do ecoturismo na região. No Anexo B é apresentado o modelo do questionário enviado às operadoras.

Foram enviados por email, vinte questionários, sendo que seis empresas preencheram os mesmos, duas informaram não terem preenchido por não trabalharem com o PNCV e as demais não deram nenhum tipo de retorno.

As variáveis utilizadas para as pesquisas basicamente foram:

* atividades sugeridas no Plano de Uso Público do PNCV;

* serviços e atividades existentes atualmente no Parque;

* motivação dos turistas para visitação ao Parque;

* nível de satisfação dos visitantes com as condições de uso público do Parque; e

* motivação das operadoras e agências de turismo para venda do Parque como produto ecoturístico.

Os instrumentos para a coleta de dados utilizados foram a convivência, aplicação de formulários, entrevistas com roteiros pré-determinados, análise de dados secundários, visitas de campo e documentação fotográfica.

Foram visitadas e fotografadas as trilhas atualmente abertas à visitação. Foram analisadas as atividades propostas pelo PUP. Foram entrevistados funcionários do Parque e analisados os dados obtidos durante a reunião do CONPARQUE.

Foram tabulados e analisados os dados das pesquisas com visitantes e operadoras, estabelecendo-se tabelas de porcentagem, utilizando-se para cálculos e elaboração de gráficos a planilha Excel. A análise dos dados foi efetuada de forma descritiva e analítica, confrontando o referencial teórico levantado nos Planos do PNCV, livros diversos sobre o tema e os resultados obtidos na pesquisa. 


\section{4 - RESULTADOS E ANÁliSE DAS PESQUISAS}

\section{1 - VISITA AO PARQUE E ATRATIVOS}

Nos dias 23 de junho, 7 e 8 de setembro e 15 e 16 de novembro de 2002, foram procedidas visitas de campo às áreas do Parque e seus atrativos, para fins de conhecimento dos serviços e atividades disponibilizados pelo Parque aos visitantes e suas condições.

Da visita, devidamente documentada através de fotografias, foi constatada a seguinte situação:

* estacionamento pequeno para a demanda de uso nos finais de semana e feriados e sem sinalização;

* $\quad$ entrada de acesso ao Parque em condições precárias;

* cobrança de ingresso por meio de sistema manual através de serviço terceirizado;

* presença de pessoal da Instituição somente no Portão de entrada do Parque;

* inexistência de sanitários públicos;

* existência de coletores de lixo somente na entrada do Parque, como estratégia de educação e participação maior do visitante no recolhimento do seu lixo;

* serviço de condução de visitantes efetuado por terceiros sem amparo legal;

* dificuldades constantes do pessoal do Parque com relação aos visitantes no portão de entrada, por falta de condutores, mesmo havendo margem para a capacidade de carga utilizada que é de 300 pessoas/dia;

* entrada permitida somente com condutores locais, em grupos de no máximo 10 pessoas;

* $\quad$ valor cobrado pelo condutor de R\$ 5,00 por pessoa;

* Valor do bilhete de entrada no Parque de R \$ 3,00 por pessoa;

* inexistência de condições necessárias para acesso a qualquer parte do Parque por portadores de deficiência física;

centro de visitantes sem funcionamento, prédio em utilização para a Administração do Parque; 
* existência de um bebedouro em condições precárias, na varanda do prédio do centro de visitantes;

* inexistência de instrumentos de avaliação da satisfação, opiniões e sugestões dos visitantes, por parte do IBAMA;

* inexistência de informações, material e atividades educativas quaisquer por parte do IBAMA;

* inexistência de sinalização nas trilhas, atrativos e locais de perigo;

* $\quad$ inexistência de trilhas auto-guiadas e auto-interpretativas;

* trilhas abertas ao público em processo crescente de erosão;

* inexistência de monitoramento nos atrativos do número de visitantes, que no geral extrapolam a capacidade de carga permitida por área nos finais de semana;

* dejetos sólidos em áreas próximas às trilhas, ocasionada pela inexistência de sanitários; e

* não implantação das trilhas novas propostas pelo PM e pelo PUP, com a permanência somente das trilhas e atrativos que já se encontravam abertos à época do PAE (1995).

\section{2 - O PLANO DE USO PÚBLICO DO PNCV}

O Plano de Uso Público, apesar de conter sugestões interessantes, como novas atividades e trilhas, disponibilização de transporte para pessoas da terceira idade e implantação de mecanismos de segurança, dentre outros, nunca foi implementado. As atividades que continuam sendo realizadas são as mesmas apontadas como em funcionamento pelo Plano de Manejo e, mais que isto, são as mesmas apontadas pelo PAE, em 1995.

Cabe ressaltar a importância das recomendações constantes no PUP, da necessidade dos estudos de capacidade de carga para cada trilha, da regularização da situação dos condutores de visitantes e da necessidade de implementação de um sistema de segurança.

À época da elaboração do PUP, o Parque não contava ainda com sua área ampliada, no entanto já era sugerida a ampliação das áreas de uso público.

Outro aspecto importante citado no PUP é a necessidade de melhoria das trilhas, da instalação de guarda-corpos e corrimãos e infra-estrutura mínima em alguns pontos do Parque, visando dar condições de caminhada e segurança aos visitantes. 
É apresentada com ênfase a necessidade de terceirização dos serviços e atividades no Parque, sendo que quase todas as atividades propostas são indicadas para serem terceirizadas.

Em suma, o PUP apresenta várias sugestões importantes, várias novas trilhas e atividades a serem implementadas e detalha projetos para a implantação de infra-estrutura básica, sinalização, interpretação e orientações sobre a implementação do centro de visitantes.

Indica a necessidade de recuperação da estrada administrativa para uso de transporte para atender pessoas com dificuldades físicas, indica os locais que deverão ser sinalizados, inclusive oferece modelos, tipos e textos para a sinalização e interpretação, além de outras sugestões em várias áreas, tudo voltado para a implementação do uso público no mesmo, no entanto nada foi executado até o presente momento pelo IBAMA.

\section{3 - PESQUISA COM OS VISITANTES}

\subsection{1 - Perfil do Visitante}

Esta pesquisa foi efetuada nos dias 7 e 8 de setembro e posteriormente nos dias 14 , 15 e 16 de novembro de 2002. No total foram respondidos cem questionários sendo $44 \%$ de participantes homens e $56 \%$ mulheres.

Quanto à idade dos entrevistados, os maiores percentuais estão situados entre 27 e 34 anos (45\%) e 19 a 26 anos (35\%), conforme pode ser visto na Figura 9.

Em relação ao grau de instrução, $45 \%$ possuem segundo grau; $35 \%$ possuem curso superior, acrescido de mais $19 \%$ com pós-graduação. Observa-se que $1 \%$ dos visitantes possui somente primeiro grau, conforme apresentado na Figura 9.

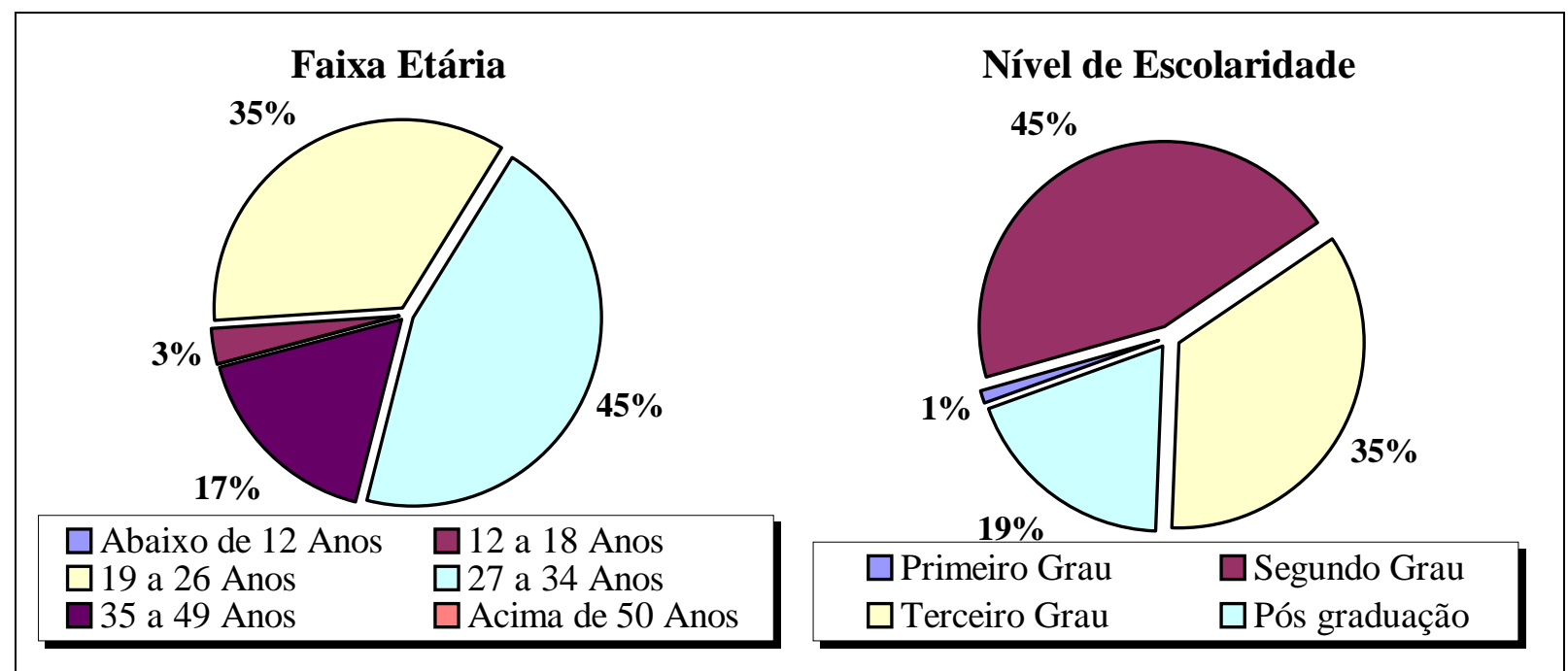

Figura 9 - Faixa Etária e Nível de Escolaridade de Cem Visitantes do PNCV 
No que diz respeito à origem dos mesmos, foi constatado que 52\% são oriundos de Brasília; $20 \%$ de Goiás e 7\% de São Paulo, sendo esses os estados com maior participação na visitação do Parque.

Entre os entrevistados, $59 \%$ são solteiros; $35 \%$ são casados e $6 \%$ desquitados, sendo que dentre os mesmos, $82 \%$ não possuem filhos e $13 \%$ possuem entre 1 e 2 filhos.

Os indivíduos entrevistados possuem faixas de renda mensal variadas, sendo as faixas mais representativas, $24 \%$ com renda mensal entre $\mathrm{R} \$ 2.001,00$ e $\mathrm{R} \$ 3.000,00 ; 21 \%$ encontram-se na faixa de $\mathrm{R} \$ 201,00$ a $\mathrm{R} \$ 500,00 ; 16 \%$ na faixa entre $\mathrm{R} \$ 501,00$ a $\mathrm{R} \$$ $1.000,00 ; 15 \%$ na faixa entre $\mathrm{R} \$ 3.001,00$ a $\mathrm{R} \$ 5.000,00$ e $11 \%$ se encontram na faixa entre $\mathrm{R} \$ 1.001,00$ e $\mathrm{R} \$ 2.000,00$. A Figura 10 apresenta a faixa de renda mensal dos entrevistados.

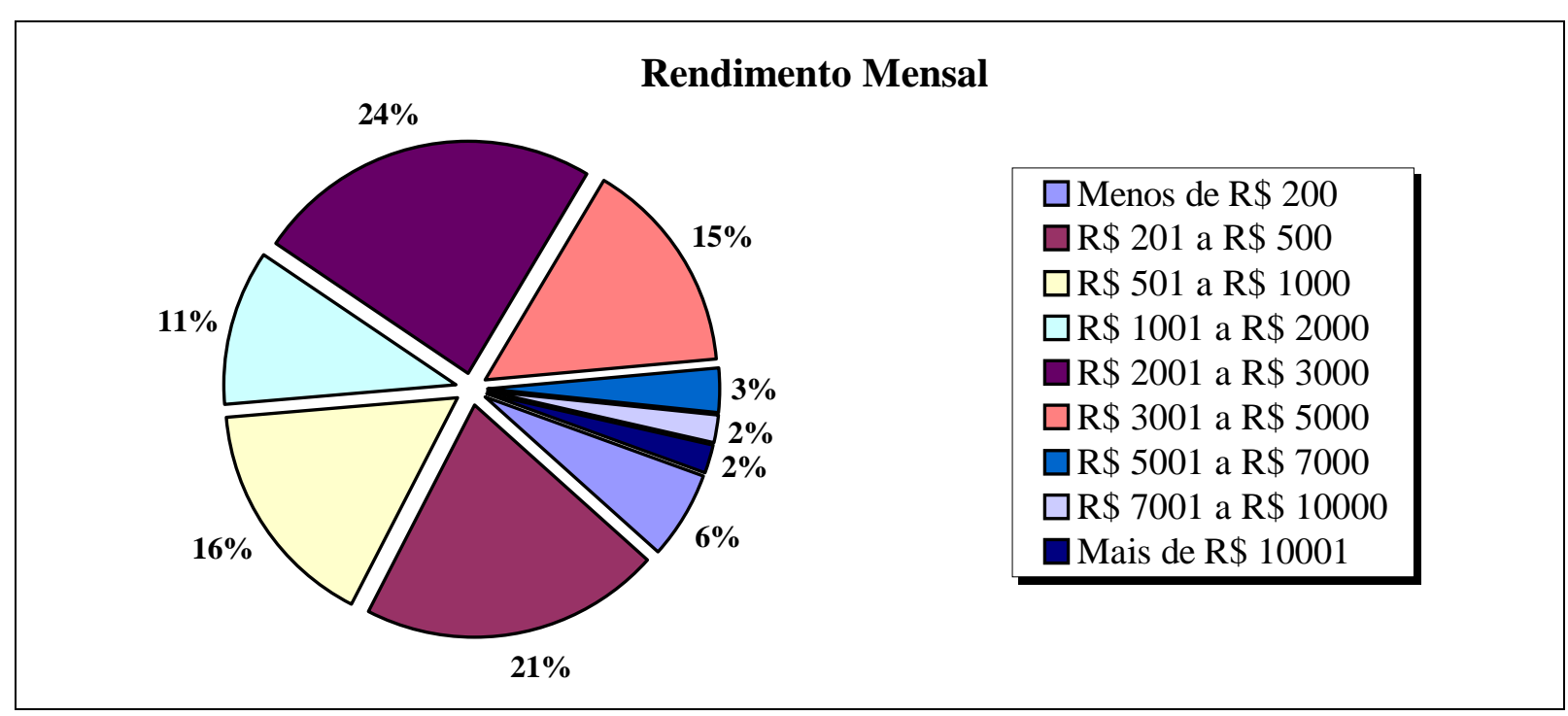

Figura 10 - Rendimento Mensal de Cem Visitantes do PNCV

Foi levantado ainda, o montante de recursos gastos durante a permanência no Distrito de São Jorge e no Parque, sendo que 39\% gastaram entre R \$ 201,00 a R \$ 400,00; $16 \%$ entre $\mathrm{R} \$ 401,00$ e R \$ 600,00; o mesmo percentual anterior gastou até R\$100,00 e 15\% gastaram entre R\$ 101,00 e R\$ 200,00. Nenhum entrevistado gastou acima de R\$ 1.000,00; 7\% gastaram entre $\mathrm{R} \$ 601,00$ e $\mathrm{R} \$ 800,00$ e 5\% gastaram entre $\mathrm{R} \$ 801,00$ e $\mathrm{R} \$ 1.000,00$.

Com relação a forma como viajam, foi constatado que 55\% dos visitantes viajam em grupos; $32 \%$ viajam com o(a) companheiro(a); $7 \%$ viajam sós e $5 \%$ viajam com a família. Dos visitantes que viajam em grupo, os segmentos mais representativos foram dois, sendo $53 \%$ que viajam em grupos de amigos e $25 \%$ em grupos de estudantes, que no geral visitam o Parque em trabalhos de campo de suas Universidades e Escolas, tanto de Brasília como de Goiás.

Dos visitantes pesquisados, $50 \%$ viajam até duas vezes ao ano; $30 \%$ entre três e cinco vezes ao ano e $20 \%$ viajam mais de seis vezes ao ano. 
No que diz respeito ao conhecimento do Parque e tempo de permanência no local, pode-se constatar abaixo na Figura 11, que a maioria dos entrevistados não conhecia o Parque, sendo sua primeira visita e que a permanência da maioria está entre dois e três dias.

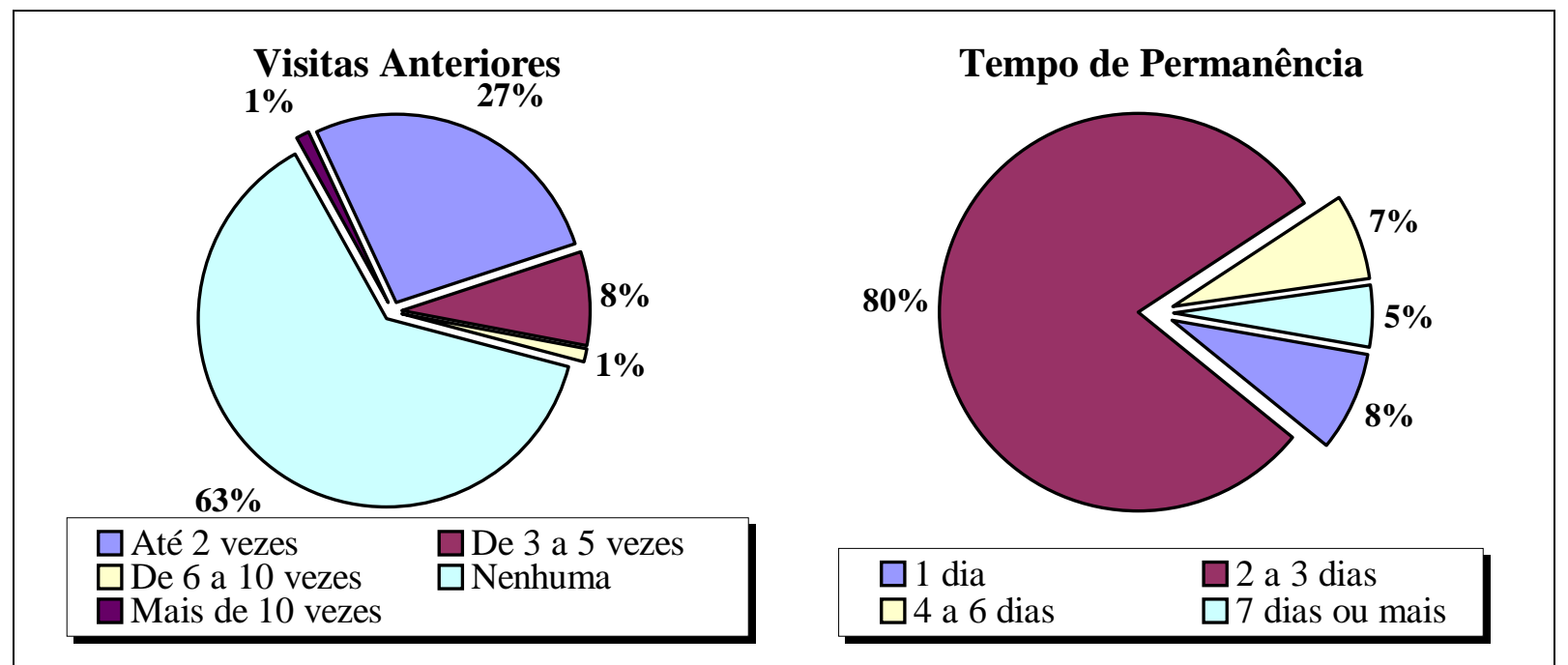

Figura 11 - Visitas Anteriores e Tempo de Permanência de Cem Visitantes do PNCV

Os meios de locomoção utilizados indicaram que $71 \%$ viajam em carro próprio; $12 \%$ em ônibus fretado; $7 \%$ em ônibus de linha; $6 \%$ em carro alugado e $4 \%$ não especificaram a forma de locomoção.

As atividades preferidas praticadas pelos entrevistados na localidade indicaram a prioridade para os banhos de cachoeira, as caminhadas e as trilhas já existentes no Parque. $\mathrm{O}$ meio de hospedagem mais utilizado de acordo com a pesquisa, são as pousadas locais conforme demonstrado na Figura 12.

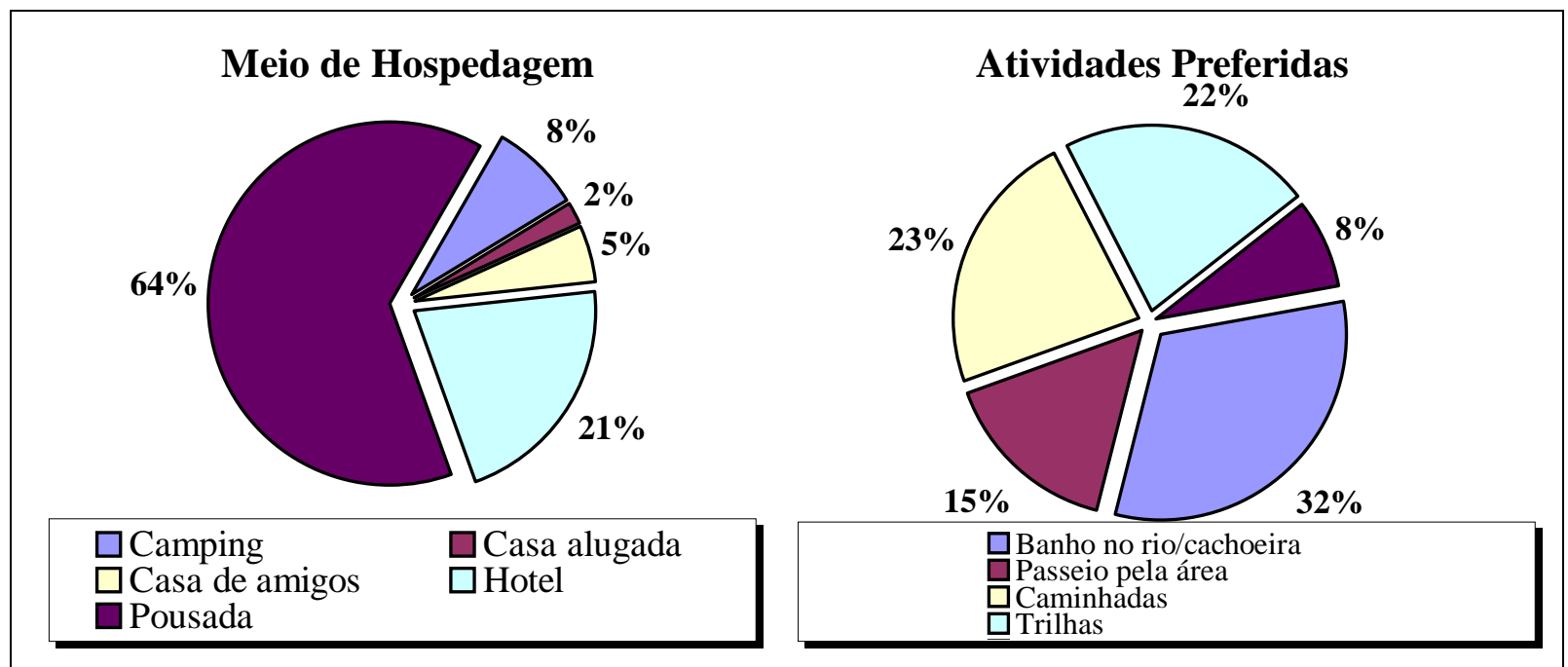

Figura 12 - Meio de Hospedagem e Atividades Preferidas de Cem Visitantes do PNCV 
Quanto aos motivos da visita ao Parque, os percentuais mais representativos dizem respeito ao conhecer a Unidade, contato com a natureza e a busca de local para descanso, conforme demonstrado a seguir na Figura 13.

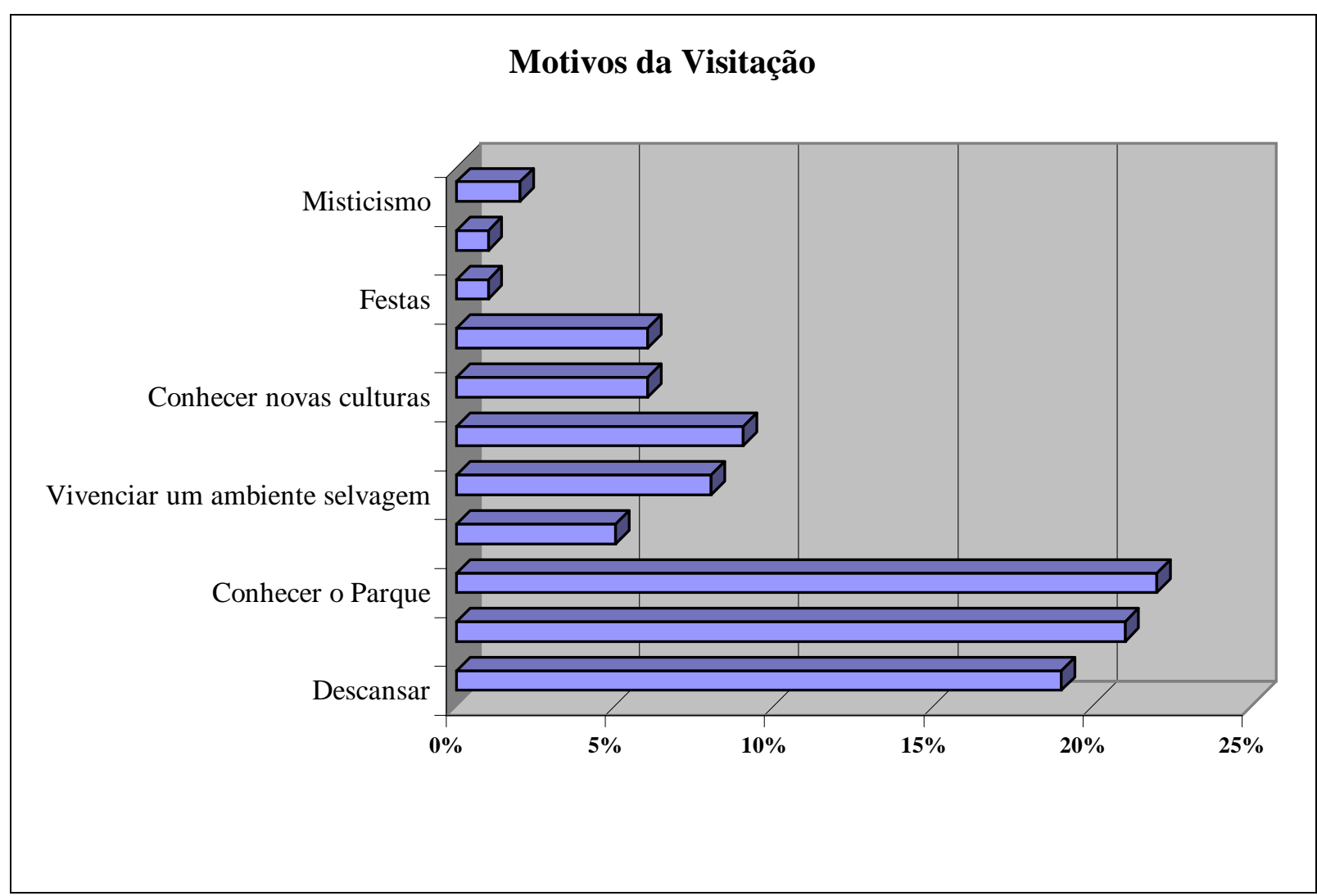

Figura 13 - Motivos da Visitação de Cem Visitantes ao PNCV

Entre os pesquisados, a maioria (61\%) tomou conhecimento do Parque por recomendação de amigos e conhecidos, conforme demonstrado a seguir na Figura 14.

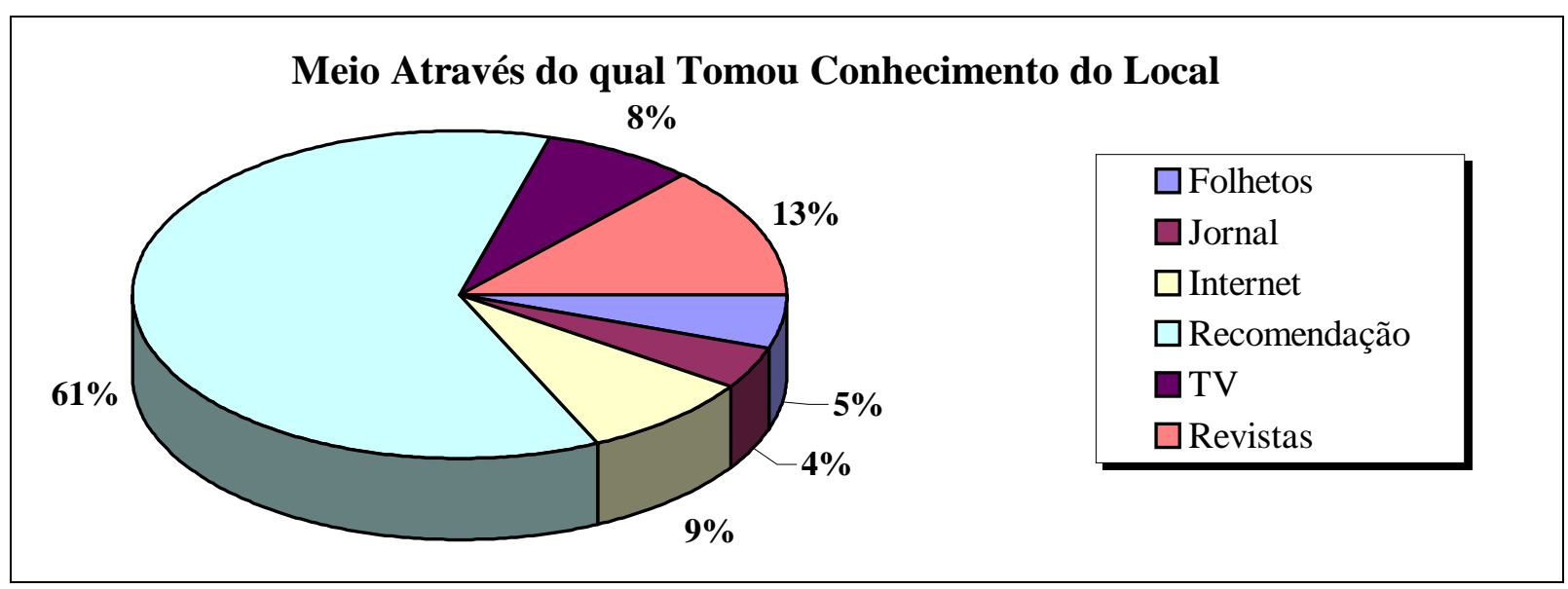

Figura 14 - Meio pelo qual Cem Visitantes Tomaram Conhecimento do PNCV 


\subsection{2 - Informações sobre a Visita ao PNCV}

Um dos tópicos do questionário solicitava avaliação sobre as atividades e serviços do Parque, especificamente sobre acesso, alimentação, preços, limpeza, sinalização, trilhas, condutores, informações, segurança, atendimento e sobre o centro de visitantes.

No que diz respeito ao acesso, a maioria dos entrevistados julgou o acesso entre bom e regular (61\%). Quanto à alimentação, 32\% assinalaram a inexistência de serviços de alimentação no Parque, sendo no entanto que $27 \%$ consideraram a alimentação boa.

Os preços cobrados no Parque foram julgados bons para $42 \%$ dos visitantes e regular para $23 \%$. No tópico referente à limpeza, $73 \%$ julgaram que a limpeza do Parque está entre muito boa e ótima. Com relação à sinalização do Parque, $34 \%$ consideraram boa, sendo que $37 \%$ avaliaram entre inexistente e ruim.

As trilhas hoje em funcionamento no Parque foram avaliadas pela maioria (77\%) entre bom e muito bom. Os condutores foram avaliados como ótimos por $41 \%$ dos visitantes, como muito bom por $28 \%$ e como bom por $23 \%$ dos entrevistados. O quesito de informações no Parque demonstrou que $31 \%$ consideraram as informações disponibilizadas pelo Parque muito boas, $28 \%$ como boas, $19 \%$ como ótimas e somente $6 \%$ como inexistentes.

Para o item de segurança os percentuais obtidos foram de $37 \%$ para muito bom, $30 \%$ para bom, $17 \%$ classificaram como ótimo e $16 \%$ entre inexistente e regular. Quanto ao atendimento, $35 \%$ dos visitantes o classificaram como bom; $29 \%$ como muito bom; $20 \%$ como ótimo, e $16 \%$ classificaram o atendimento entre inexistente e regular.

O último item deste quesito previa a avaliação do centro de visitantes, tendo obtido um percentual de 32,\% para bom; $21 \%$ para inexistente; $17 \%$ para regular; $16 \%$ para muito bom; $12 \%$ classificaram como ótimo e $3 \%$ como ruim.

Foi elaborado item, visando identificar que tipo de equipamentos e serviços os entrevistados gostariam de encontrar no Parque, tendo sido o item lixeiras o mais significativo, ficando em segundo lugar os itens primeiros socorros, trilhas sinalizadas e sanitários conforme apresentado na Figura 15.

No que diz respeito ao item de locação, foram listados os seguintes equipamentos: bicicletas, máscara e respiradouro para mergulho, ônibus e vans. Outras atividades e serviços listados foram: bancos, instalação de ducha para uso pelos visitantes quando do retorno das trilhas, fotógrafos nos atrativos, equitação, mergulho, lanchonete, venda de água, palestras, apresentação de eslaides sobre o Parque, sorveteria, trilhas com bicicletas, trilhas por temas como orquídeas ou animais, diminuir o número de pessoas nas trilhas e horários alternativos. 


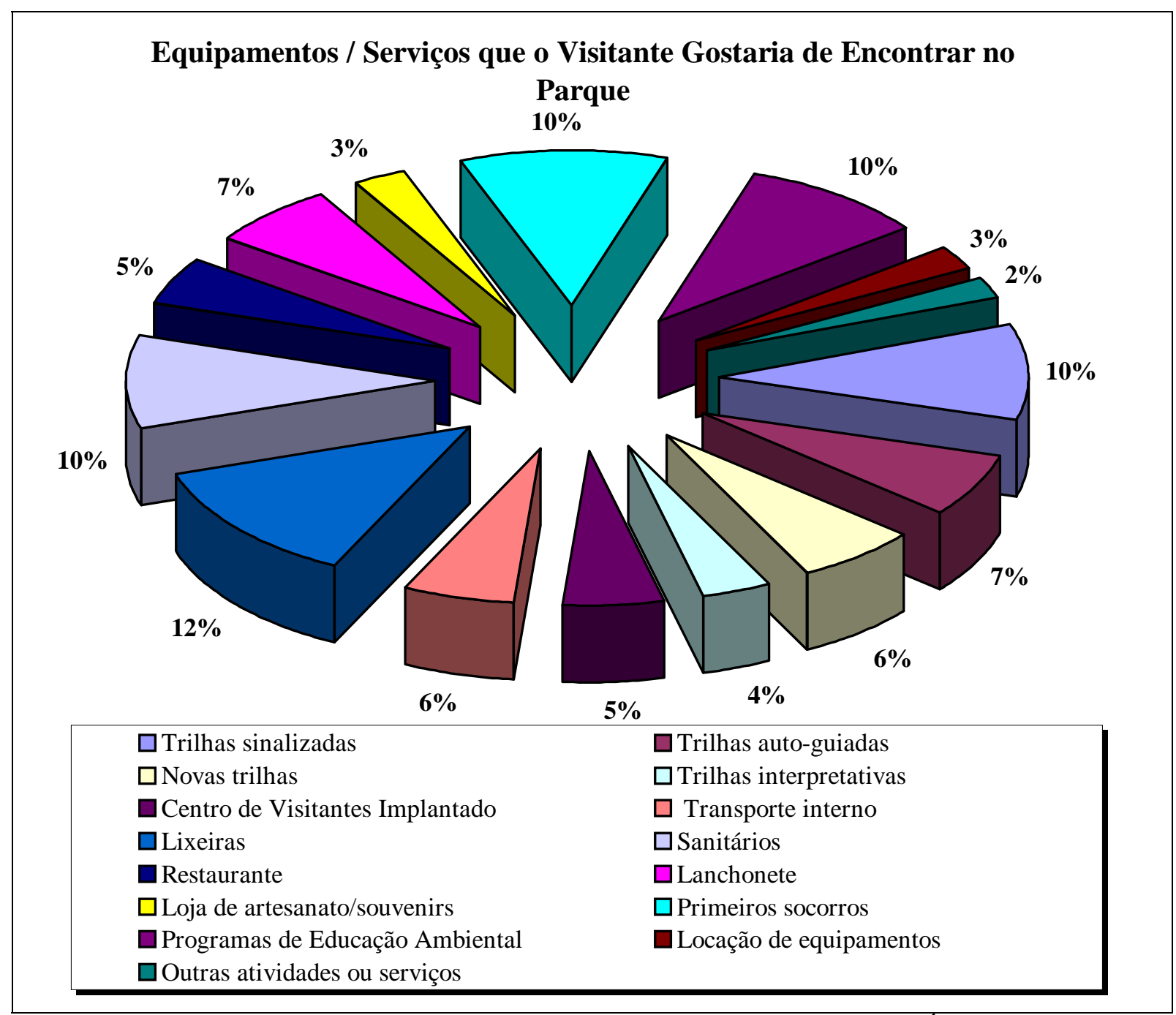

Figura 15 - Equipamentos e Serviços Apontados como Prioritários na Área do PNCV por Cem Visitantes

\subsection{3 - Atividades e Serviços no Distrito de São Jorge}

Outra avaliação efetuada junto aos visitantes dizia respeito às atividades e serviços no Distrito de São Jorge, que deveriam ser classificados em inexistente, ruim, regular, bom, muito bom e ótimo.

Com relação ao acesso, a maioria dos visitantes $(72 \%)$ considerou o mesmo entre ruim e regular. A alimentação foi considerada por $50 \%$ como boa; $19 \%$ consideraram muito boa; $13 \%$ como regular; $12 \%$ como ótima e os demais $(6 \%)$ entre ruim e inexistente.

Os preços praticados no Distrito de São Jorge foram considerados pela maioria entre bom e regular (71\%); e o item limpeza da cidade também foi considerado pela maioria como bom e muito bom (65\%). 
No que diz respeito à sinalização, esta foi considerada por $35 \%$ como regular; por $24 \%$ como boa; $20 \%$ a consideraram ruim, sendo que os demais ficaram quase que igualmente divididos entre inexistente, muito bom e ótimo.

No item referente à hospedagem, os visitantes julgaram-na, em sua maioria, (68\%) entre boa e muito boa; e a segurança também foi considerada por $66 \%$ como muito boa e boa.

Quanto à disponibilidade de informações, $34 \%$ a consideraram boa; $26 \%$ consideraram-na muito boa; $22 \%$ consideraram-na regular; $12 \%$ ótima e $6 \%$ entre ruim e regular. A parte de comunicações (telefonia etc.) foi considerada pela maioria entre bom e regular $(68 \%)$.

$\mathrm{Na}$ área de comércio foram levantados dois tipos de dados, um com relação ao comércio geral do Distrito, que foi considerado pela maioria entre bom e regular (77\%) e o item artesanato teve também a mesma avaliação pela maioria, obtendo na classificação um percentual de $58 \%$.

O interesse dos turistas com relação aos serviços no Parque e seu entorno, apontam como menos indicados a culinária local e o de esporte de aventura conforme apresentado na Figura 16.

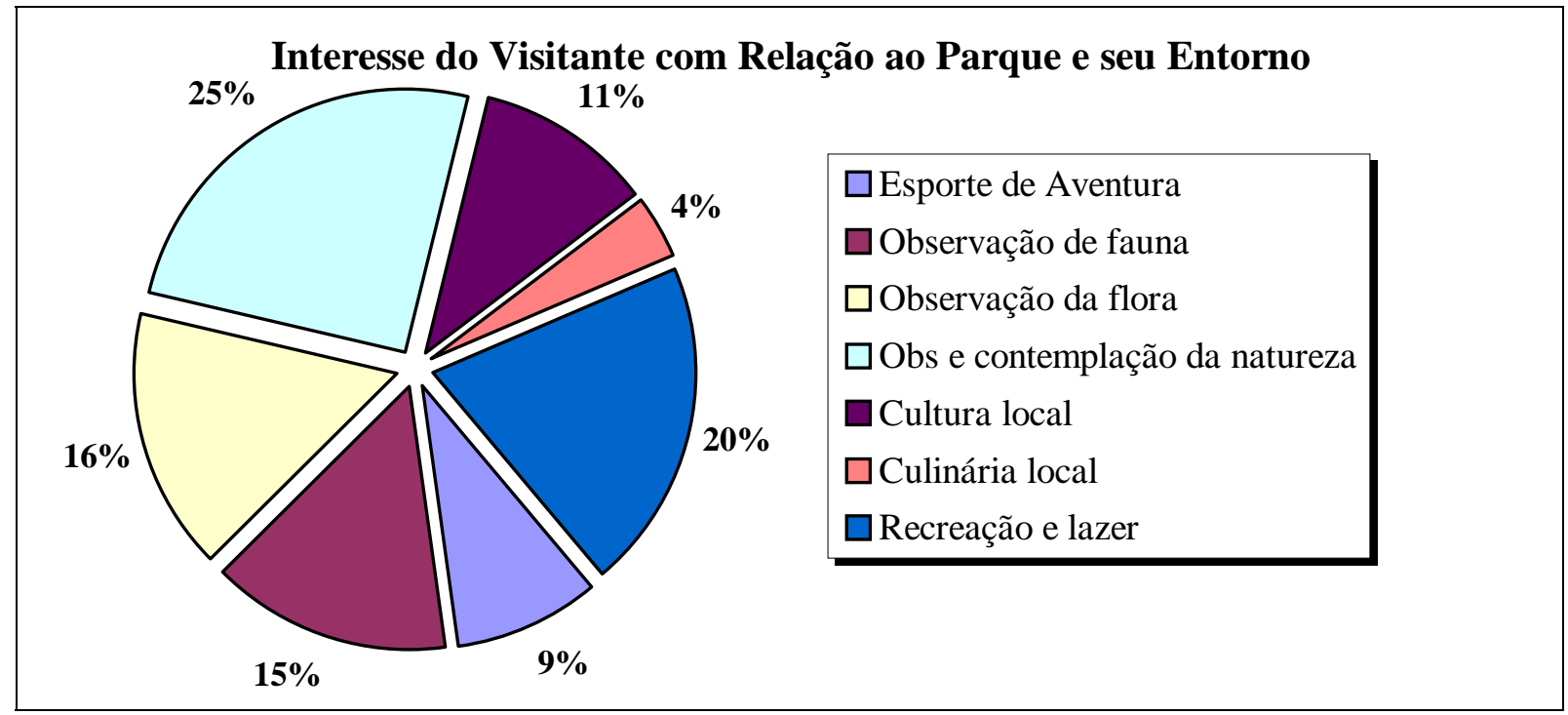

Figura 16 - Interesse com Relação ao Parque e seu Entorno de Cem Visitantes do PNCV

Quando perguntado sobre a qualidade dos serviços, com relação a diversos itens, a serem pontuados entre muito baixo, baixo, médio, alto e muito alto, percebe-se que a maioria tem um nível de exigência médio para quase todos os itens, com exceção de atratividade da natureza, qualidade das atrações, limpeza, preparo dos condutores, preservação da natureza e qualidade das informações conforme mostra a Figura 17. 


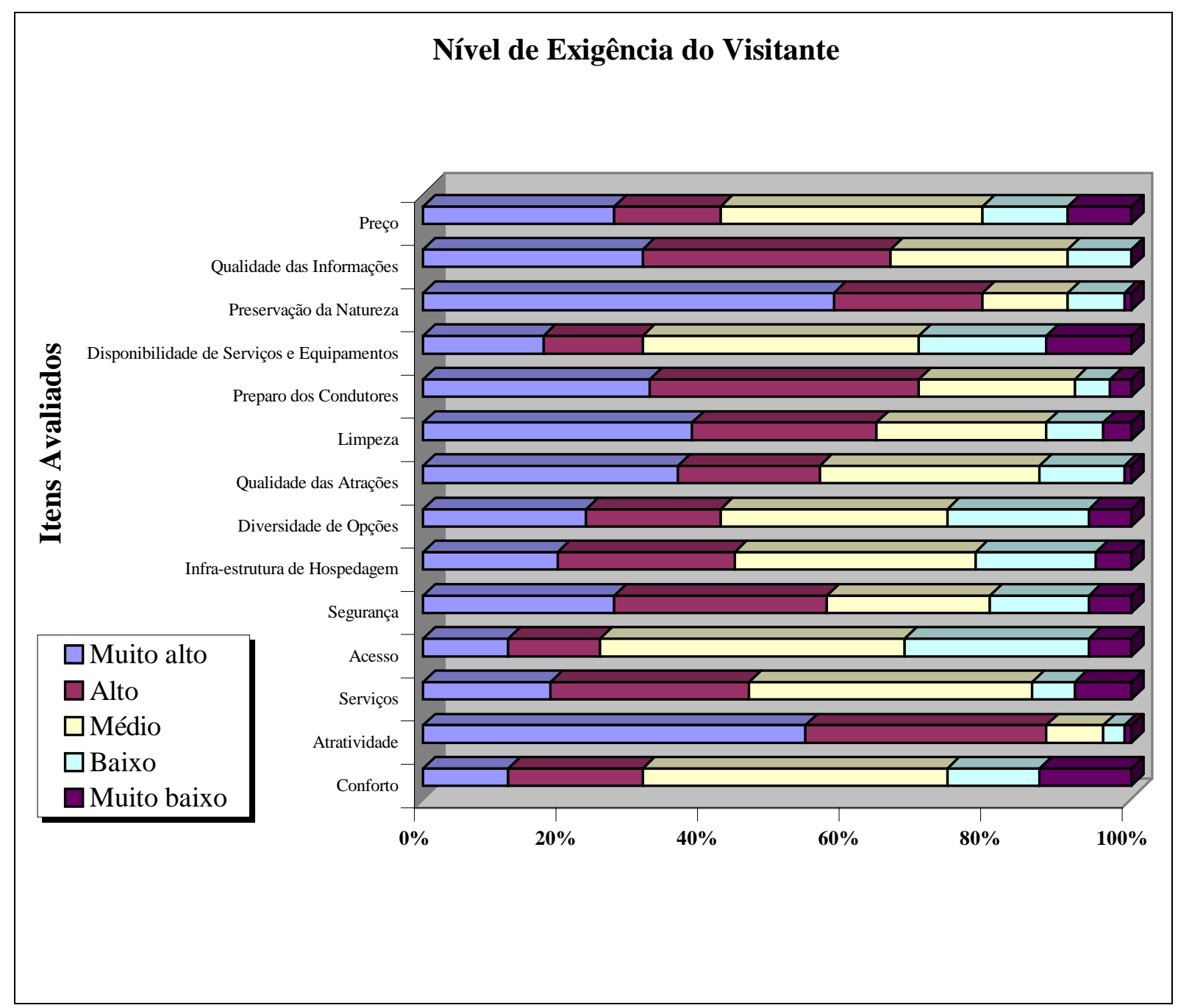

Figura 17 - Nível de Exigência Apresentado por Cem Visitantes no PNCV

\section{4 - PESQUISA COM OPERADORAS E AGÊNCIAS DE TURISMO}

Outra forma utilizada de pesquisa foi pela Internet. Foram enviados vinte formulários a operadoras e agências de turismo que trabalham com ecoturismo no país, sendo que seis delas responderam à pesquisa, e duas não responderam por alegar não trabalhar com a área do Parque. Os resultados da pesquisa são apresentados a seguir.

Das seis empresas que trabalham com ecoturismo, todas trabalham também com outro tipo de turismo, na sua maioria com áreas naturais conforme pode ser visto na Figura 18.

As empresas pesquisadas trabalham todas com vendas de pacotes pela Internet e $84 \%$ vendem pacotes para agências e também diretamente ao turista. 


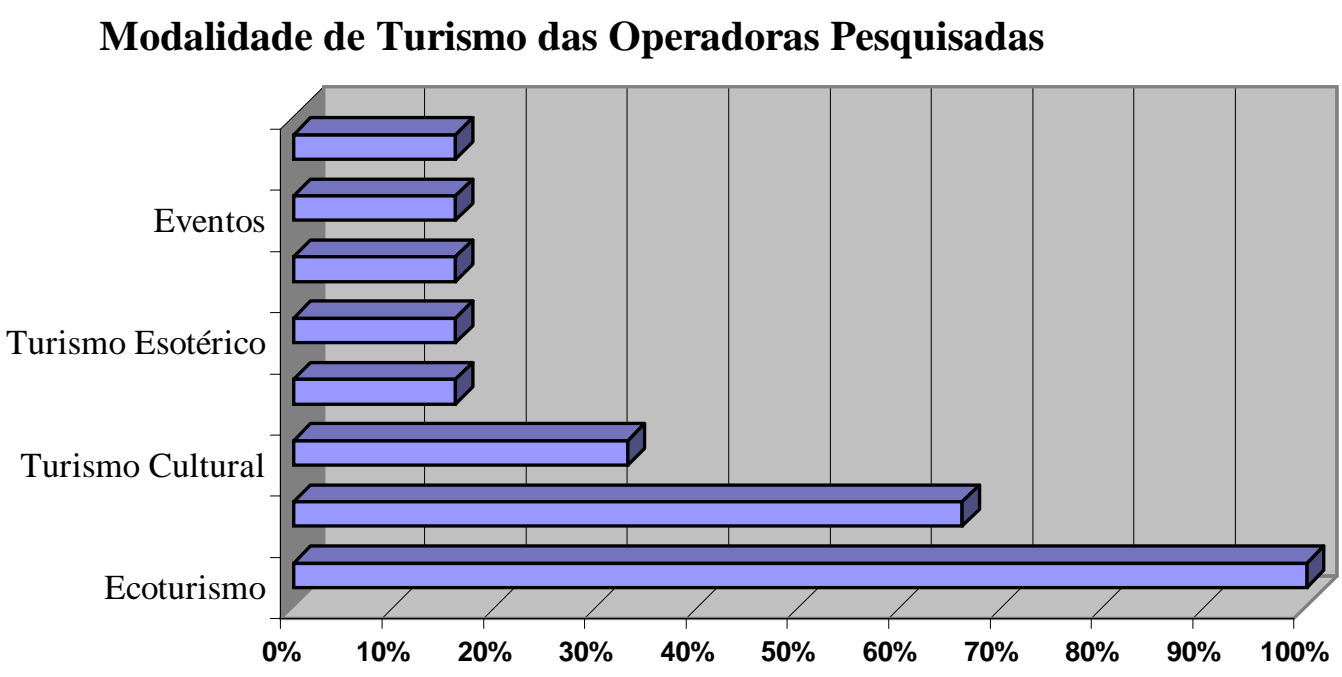

Figura 18 - Modalidade de Turismo Executado por Seis Operadoras de Ecoturismo

Para $68 \%$ das empresas o número de vendas com finalidade ecoturistica está na faixa de 700 viagens por ano e sua maior clientela é de São Paulo, mas contando com clientes em outros estados brasileiros e no exterior de acordo com a Figura 19.

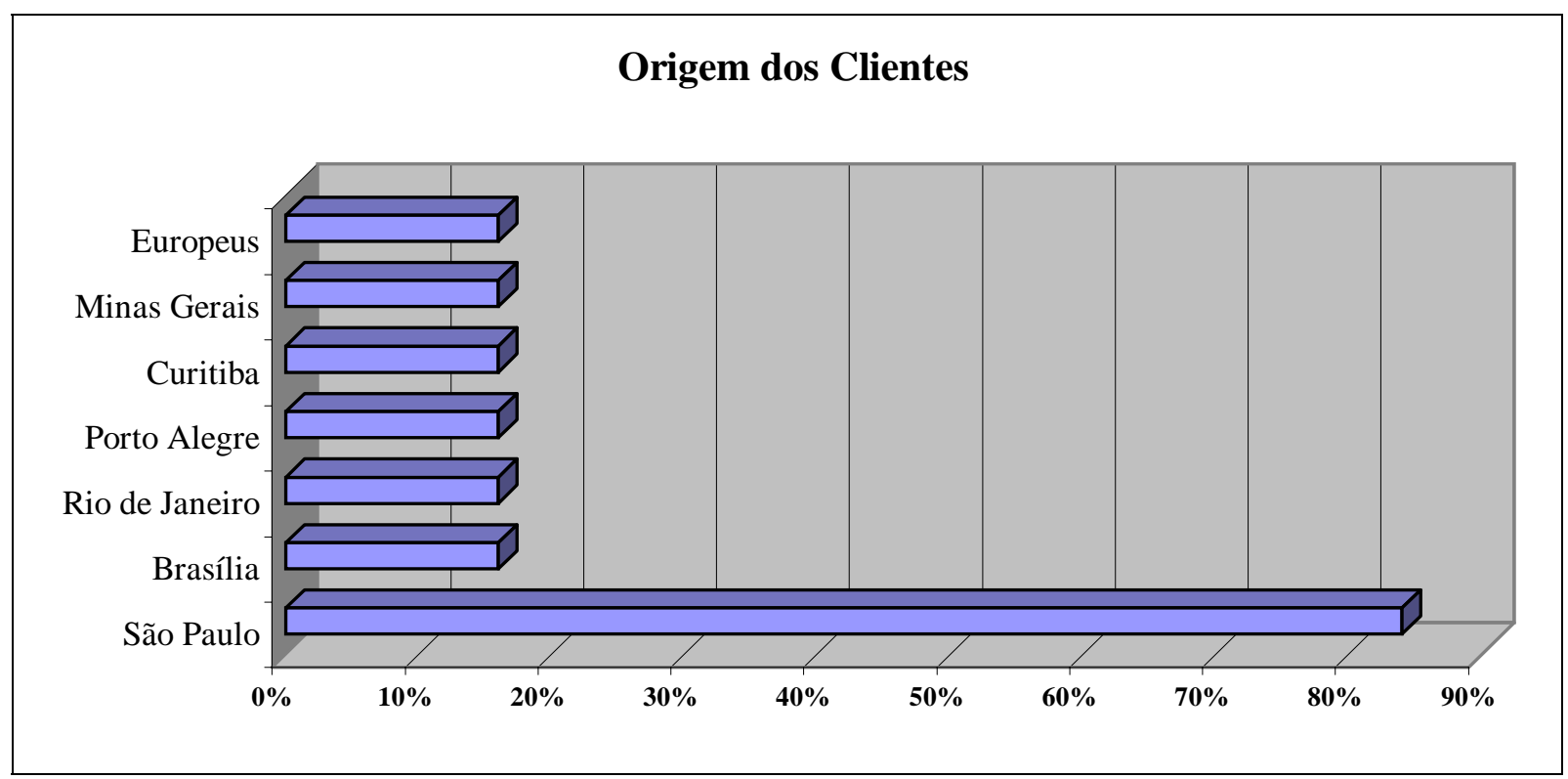

Figura 19 - Origem dos Clientes Atendidos por Seis Operadoras de Ecoturismo

Das empresas pesquisadas, $100 \%$ trabalham com parques e outras áreas protegidas (RPPNs, Florestas etc.) e foram elencadas as seguintes UCs: o PN da Chapada Diamantina, o PN da Chapada dos Veadeiros, o PN Marinho de Fernando de Noronha, o PN de Lençóis Maranhenses, o PN de Aparados da Serra, o PN da Serra do Cipó, o PN do Pantanal Matogrossense, o PN da Serra dos Órgãos, o PN do Iguaçu, o PN da Tijuca, o PN de Itatiaia, e o PN da Serra da Capivara. Trabalham ainda com a APA de Jericoacoara, Parque Estadual 
(PE) Turístico do Alto Ribeiro - PETAR, EcoParque de Una, PE do Conduru e PE da Ilha Grande, Reserva de Desenvolvimento Sustentável de Mamirauá, Zona de Amortecimento da Reserva Biológica de Poço das Antas, diversas Áreas de Proteção Ambiental (APA) e algumas propriedades particulares na Chapada dos Veadeiros.

Quando indagado se o PNCV está incluído no pacote das empresas e porque, $84 \%$ informaram que sim, por :

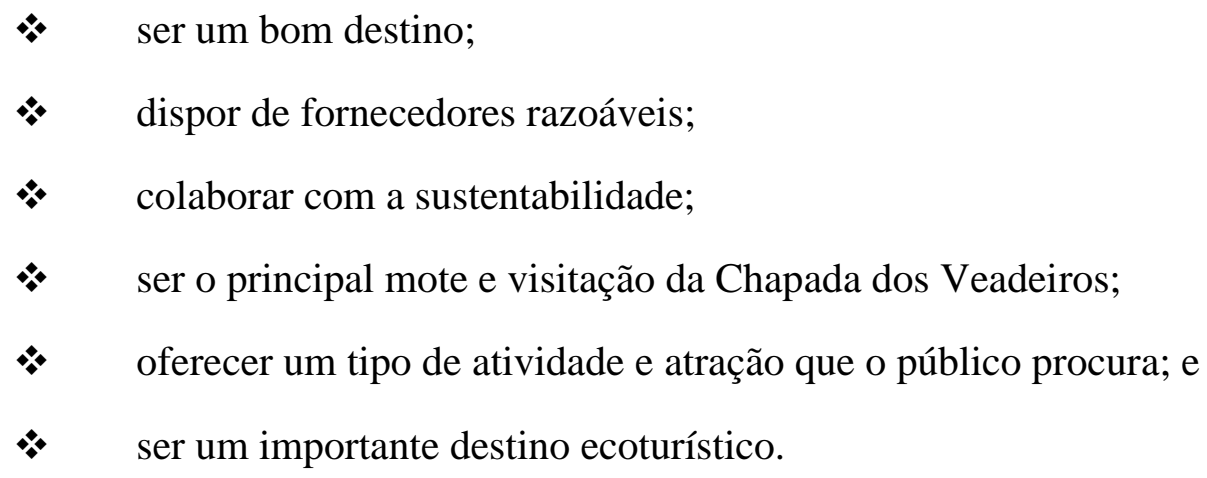

Os $16 \%$ que responderam não trabalhar com o PNCV, alegaram que o motivo seria a dificuldade de receptivo internacional, ou seja, insuficiente oferta de guias/condutores naturalistas bilingues.

Quando indagados sobre a evolução do ecoturismo na região nos próximos anos, $100 \%$ das empresas acreditam que a tendência é para o aumento da procura deste destino. E sobre que fatores julgam que poderiam vir a promover o aumento do fluxo de ecoturismo para o Parque, os fatores citados e percentuais são os abaixo representados na Figura 20.

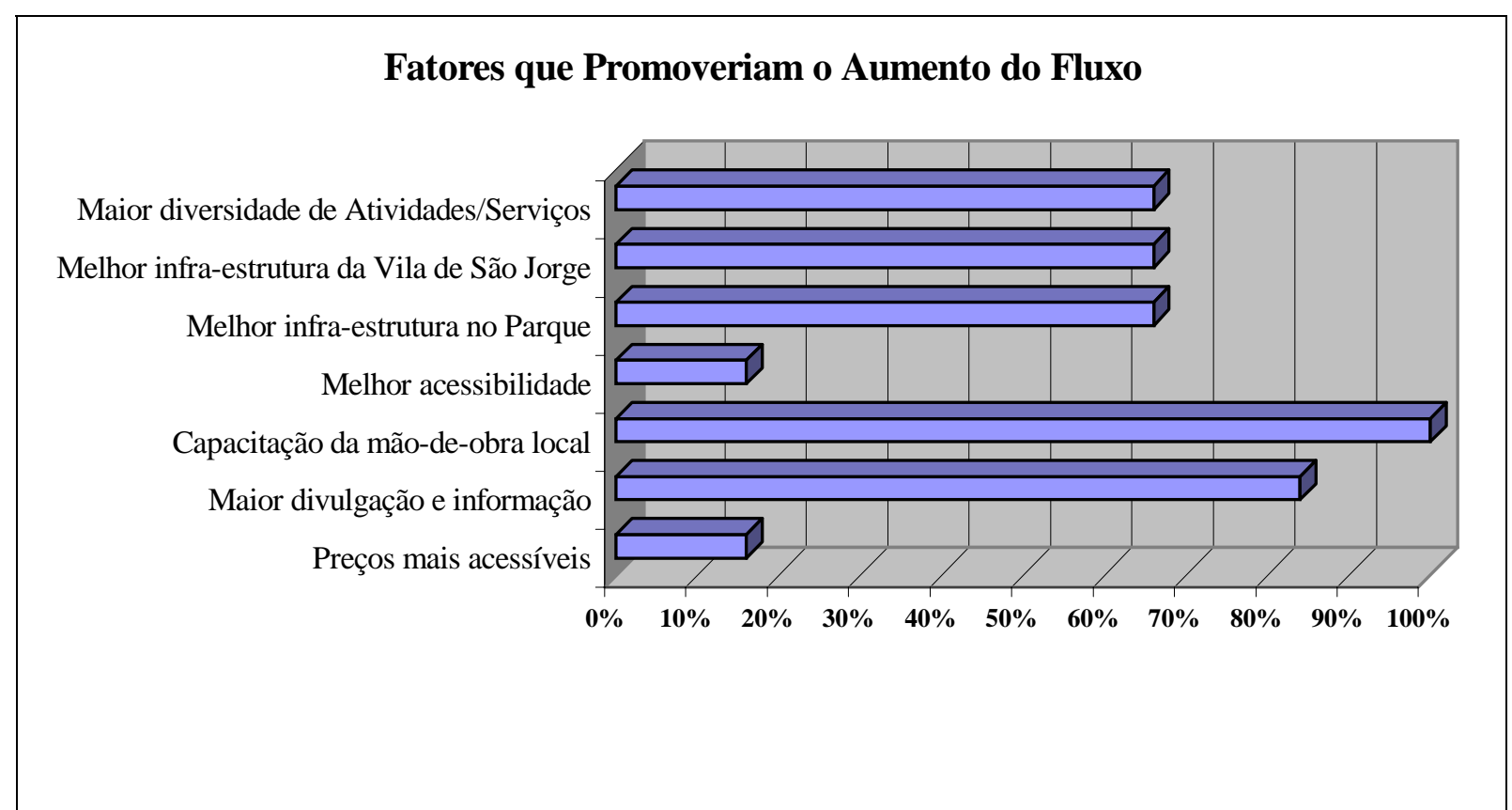

Figura 20 - Fatores que Promoveriam o Aumento do Fluxo de Ecoturistas no PNCV, Apontados por Seis Operadoras de Ecoturismo 
Foi consultado se caso a empresa não trabalhasse com o PNCV, que fatores a levariam a se dispor a fazê-lo, tendo sido levantado que seria necessária maior diversidade de atividades, de infra-estrutura e equipamentos adequados tais como: trilhas, mirantes, sanitários, centros de informação e guias naturalistas .

Sobre as prioridades dos clientes das empresas com relação a viagens ecoturísticas, foi constatado que a maioria viaja em busca de vivências na natureza de acordo com a Figura 21.

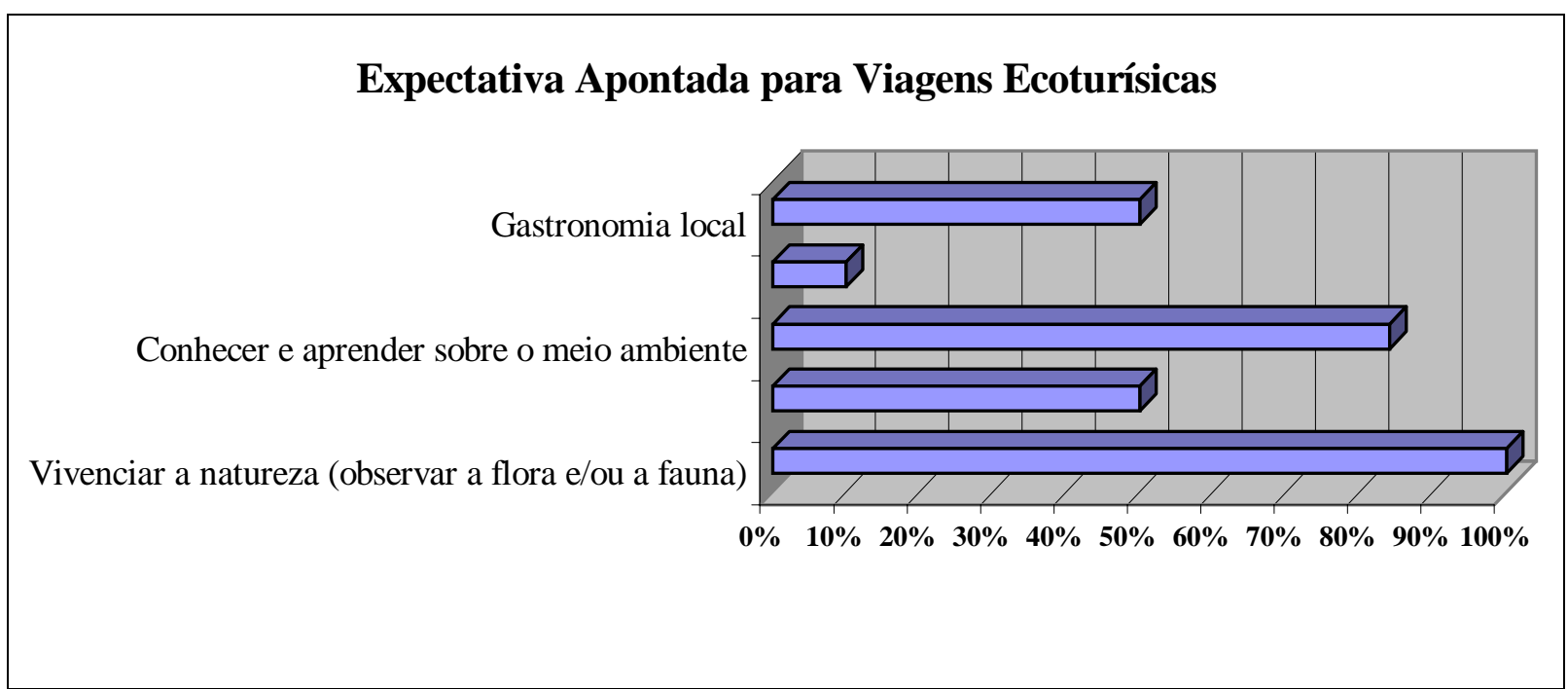

Figura 21 - Expectativa dos Turistas de Acordo com Seis Operadoras de Ecoturismo

O maior problema detectado pelas empresas para o produto ecoturístico do PNCV é o fator divulgação, tanto no âmbito nacional como internacional, depois vem o problema de infra-estrutura, a falta de acessibilidade aos atrativos por pessoas de terceira idade e crianças e dificuldade de acesso até o Distrito de São Jorge.

Quando consultado sobre qual a melhor forma de divulgação para se atingir o ecoturista, as empresas indicaram as revistas especializadas como mostrado na Figura 22.

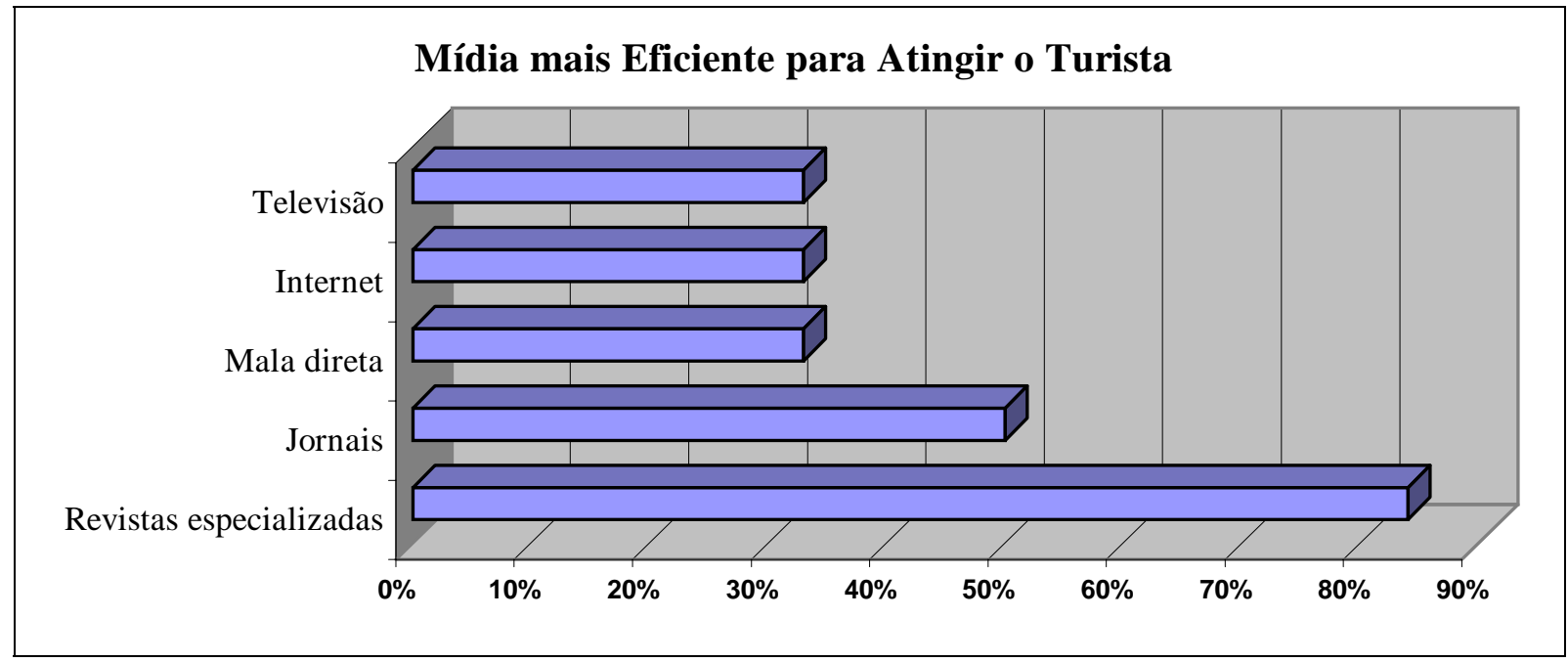

Figura 22 - Eficiência dos Meios de Divulgação Apontados por Seis Operadoras de Ecoturismo 
Foi citado também, a preocupação com a falta de segurança, ocasionada por jovens que em feriados prolongados lotam o local fazendo uso de drogas ao ar livre, provocando brigas e outros tipos de constrangimentos para famílias que ali se encontram em visitação.

A necessidade de estrutura mais direcionada ao público mais exigente também foi apontada como uma das necessidades do local.

A impossibilidade de aquisição antecipada de ingressos para a visitação ao PNCV foi apontada como um dos problemas pelas operadoras. $\mathrm{O}$ risco de não acesso permitido em função da capacidade de carga é grande em alta temporada.

O nível de satisfação da maioria dos clientes da operadora é grande (66\%) e as maiores críticas recebidas dizem respeito ao atendimento, às grandes distâncias que têm que percorrer a pé para chegar a qualquer atrativo, a frustração dos que por motivo físico não conseguem fazer as caminhadas, a inexistência de enquete para avaliar o Parque, a falta de infra-estrutura mínima e a inexistência de sinalização e informação.

Foi solicitado à empresa que informasse outros destinos turísticos operados, o nível de satisfação em relação aos mesmos e sua avaliação em relação à atratividade do PNCV em comparação com estes destinos. Essa avaliação incluiu o preço médio cobrado pelo pacote contendo transporte, alojamento, tour e alimentação. Estas informações podem ser vistas na

\section{Tabela 6.}

Tabela 6 - Outros Destinos Turísticos Praticados por Seis Operadoras de Ecoturismo

\begin{tabular}{|c|c|c|c|c|}
\hline $\begin{array}{l}\text { Destinos } \\
\text { Ecoturísticos }\end{array}$ & $\begin{array}{l}\text { Nível de } \\
\text { Satisfação }\end{array}$ & $\begin{array}{l}\text { Atratividade } \\
\text { do PNCV }\end{array}$ & \begin{tabular}{|l} 
Preço Médio do \\
Pacote
\end{tabular} & Observações \\
\hline Amazônia & $\begin{array}{l}\text { Regular } 50 \% \\
\text { Muito bom } 50 \%\end{array}$ & Média & $\begin{array}{l}\text { Acima de R\$ } 2000 \\
\text { Permanência média } \\
4 \text { dias/3 noites = } \\
\text { US\$ } 600 \text { / US\$ } \\
2100, \text { exclusive } \\
\text { bilhete aéreo (1 } \\
\text { US\$ = 3,5 R\$) }\end{array}$ & $\begin{array}{l}\text { Necessita melhorias no } \\
\text { atendimento - guias } \\
\text { naturalistas bilingües } \\
\text { adequadamente } \\
\text { capacitados e } \\
\text { treinados. Em geral } \\
\text { suprimos deficiências } \\
\text { contratando } \\
\text { guias/condutores } \\
\text { extras. }\end{array}$ \\
\hline Bonito & $\begin{array}{l}\text { Bom } 25 \% \\
\text { Muito bom } 50 \% \\
\text { Ótimo } 25 \%\end{array}$ & Média & $\mathrm{R} \$ 1001$ a $\mathrm{R} \$ 2000$ & \\
\hline $\begin{array}{l}\text { Chapada } \\
\text { Diamantina }\end{array}$ & $\begin{array}{l}\text { Muito bom } 50 \% \\
\text { Ótimo } 50 \%\end{array}$ & Média / Alta & $\mathrm{R} \$ 1001$ a $\mathrm{R} \$ 2000$ & Um lugar fantástico \\
\hline
\end{tabular}


Tabela 6 - Outros Destinos Turísticos Praticados por Seis Operadoras de Ecoturismo (continuação)

\begin{tabular}{|c|c|c|c|c|}
\hline $\begin{array}{l}\text { Destinos } \\
\text { Ecoturísticos }\end{array}$ & $\begin{array}{l}\text { Nível de } \\
\text { Satisfação }\end{array}$ & $\begin{array}{l}\text { Atratividade } \\
\text { do PNCV }\end{array}$ & $\begin{array}{l}\text { Preço Médio do } \\
\text { Pacote }\end{array}$ & Observações \\
\hline $\begin{array}{l}\text { Chapada dos } \\
\text { Veadeiros }\end{array}$ & Bom $100 \%$ & $\begin{array}{l}\text { Baixa / } \\
\text { Média }\end{array}$ & $\begin{array}{l}\mathrm{R} \$ 1001 \text { a } \mathrm{R} \$ 2000 \\
\text { Preço válido para } \\
\text { roteiro de } 8 \text { dias, } \\
\text { incluindo passagem } \\
\text { aérea }\end{array}$ & $\begin{array}{l}\text { A natureza é } \\
\text { exuberante e diferente } \\
\text { o que acaba } \\
\text { compensando a falta } \\
\text { de infra-estrutura, as } \\
\text { opções de passeio são } \\
\text { muitas e existem } \\
\text { atividades como } \\
\text { terapias e vivências } \\
\text { espiritualistas ou não } \\
\text { aos visitantes que } \\
\text { buscam o relaxamento } \\
\text { ou crescimento pessoal }\end{array}$ \\
\hline $\begin{array}{l}\text { Fernando de } \\
\text { Noronha }\end{array}$ & $\begin{array}{l}\text { Bom 33\% } \\
\text { Muito bom 33\% } \\
\text { Ótimo 33\% }\end{array}$ & Média / Alta & $\begin{array}{l}\mathrm{R} \$ 1001 \text { a } \mathrm{R} \$ 2000 \\
\text { Acima de } \mathrm{R} \$ 2000\end{array}$ & $\begin{array}{l}\text { Com certeza um dos } \\
\text { lugares mais bonitos } \\
\text { do Brasil e do mundo }\end{array}$ \\
\hline Machu Pichu & $\begin{array}{l}\text { Bom 33\% } \\
\text { Muito bom 33\% } \\
\text { Ótimo 33\% } \\
\text { Ótimo } 100 \%\end{array}$ & Alta / Média & $\begin{array}{l}\text { US\$ } 1001 \text { a US\$ } \\
2000\end{array}$ & $\begin{array}{l}\text { Um lugar diferente, } \\
\text { com praias } \\
\text { maravilhosas }\end{array}$ \\
\hline $\begin{array}{l}\text { Mata } \\
\text { Atlântica - } \\
\text { Estado do } \\
\text { Rio de } \\
\text { Janeiro }\end{array}$ & Bom $100 \%$ & & $\begin{array}{l}\text { Acima de R\$ } 2000 \\
\text { Permanência média } \\
6 \text { dias } / 5 \text { noites = } \\
\text { US\$ } 700 \text { / US\$ } \\
2450\end{array}$ & $\begin{array}{l}\text { Necessita melhorias no } \\
\text { atendimento - guias } \\
\text { naturalistas bilinguies } \\
\text { adequadamente } \\
\text { capacitados e } \\
\text { treinados. Em geral } \\
\text { suprimos deficiências } \\
\text { contratando } \\
\text { guias/condutores } \\
\text { extras. }\end{array}$ \\
\hline $\begin{array}{l}\text { Mata } \\
\text { Atlântica - } \\
\text { Litoral e } \\
\text { Ilhas } \\
\text { Oceânicas }\end{array}$ & Bom $100 \%$ & & $\begin{array}{l}\text { Acima de R\$ } 2000 \\
\text { Permanência média } \\
5 \text { dias } / 3 \text { noites }= \\
\text { US\$ } 600 \text { / US\$ } \\
2100\end{array}$ & $\begin{array}{l}\text { Necessita melhorias no } \\
\text { atendimento - guias } \\
\text { naturalistas bilingues } \\
\text { adequadamente } \\
\text { capacitados e } \\
\text { treinados. Em geral } \\
\text { suprimos deficiências } \\
\text { contratando } \\
\text { guias/condutores } \\
\text { extras. }\end{array}$ \\
\hline
\end{tabular}


Tabela 6 - Outros Destinos Turísticos Praticados por Seis Operadoras de Ecoturismo (continuação)

\begin{tabular}{l|l|l|l|l}
\hline $\begin{array}{l}\text { Destinos } \\
\text { Ecoturísticos }\end{array}$ & $\begin{array}{l}\text { Nível de } \\
\text { Satisfação }\end{array}$ & $\begin{array}{l}\text { Atratividade } \\
\text { do PNCV }\end{array}$ & $\begin{array}{l}\text { Preço Médio do } \\
\text { Pacote }\end{array}$ & Observações \\
\hline Pantanal & $\begin{array}{l}\text { Bom 75\% } \\
\text { Ótimo 25\% }\end{array}$ & Alta / Média & $\begin{array}{l}\text { R \$ 1001 a R\$ 2000 } \\
\text { Acima de R\$ 2000 } \\
\text { Permanência média } \\
4 \text { dias/3 noites }= \\
\text { US\$ 600 / US\$ } \\
\text { 2100, exclusive } \\
\text { bilhete aéreo }\end{array}$ & $\begin{array}{l}\text { Necessita melhorias no } \\
\text { atendimento - guias } \\
\text { naturalistas bilingües } \\
\text { adequadamente } \\
\text { capacitados e } \\
\text { treinados. Em geral } \\
\text { suprimos deficiências } \\
\text { contratando } \\
\text { guias/condutores } \\
\text { extras. }\end{array}$ \\
Patagônia & Ótimo & Média & $\begin{array}{l}\text { US\$ 1001 a US\$ } \\
2000\end{array}$ & \\
\hline
\end{tabular}

Um dos itens da pesquisa solicitava uma avaliação por parte das empresas, no que diz respeito à alguns serviços e atividades no Parque Nacional da Chapada dos Veadeiros. A avaliação e as observações das empresas constam abaixo na Tabela 7.

Tabela 7 - Avaliação de Serviços e Atividades no PNCV por Seis Operadoras de Ecoturismo

\begin{tabular}{l|l}
\hline $\begin{array}{l}\text { Tipo de Serviço / } \\
\text { Atividade }\end{array}$ & Observações \\
\hline Atendimento & $\begin{array}{l}\text { Falta preparo e profissionalismo. } \\
\text { Precisam de manutenção e abertura de novas trilhas; } \\
\text { Trilhas boas mas condutores ainda questionáveis. } \\
\text { Quase sempre está fechado ou não tem água. }\end{array}$ \\
Centro de Visitantes & $\begin{array}{l}\text { Não existe sistematicamente. Os condutores fazem uma palestrinha } \\
\text { antes de iniciar. } \\
\text { Atividades de } \\
\text { Educação Ambiental } \\
\text { Preço }\end{array}$ \\
$\begin{array}{l}\text { Verviço de condutores bem acessíveis; } \\
\text { É o mesmo valor cobrado na maioria dos outros atrativos. } \\
\text { Segurança }\end{array}$ & $\begin{array}{l}\text { Salvo algumas exceções, os condutores são bem preparados. } \\
\text { A Segurança normalmente é feita pelos próprios condutores que } \\
\text { protegem seus clientes. } \\
\text { É o principal ponto de estrangulamento à visitação. }\end{array}$ \\
Acesso & $\begin{array}{l}\text { Estão surgindo algumas pousadas charmosas; } \\
\text { Âs vezes não tem carro para atender emergências, às vezes não tem } \\
\text { água nem nos banheiros, sistema de comunicação é precário. } \\
\text { Infra-estrutura } \\
\text { São incomparáveis. }\end{array}$ \\
\hline Belezas Naturais
\end{tabular}


A mesma questão foi formulada, com relação ao Distrito de São Jorge, merecendo os comentários e avaliações abaixo descritos na Tabela 8.

Tabela 8 - Avaliação de Serviços e Atividades do Distrito de São Jorge por Seis Operadoras de Ecoturismo

\begin{tabular}{|c|c|}
\hline $\begin{array}{l}\text { Tipo de Serviço / } \\
\text { Atividade }\end{array}$ & Observações \\
\hline Hospedagem & $\begin{array}{l}\text { Estão surgindo algumas pousadas muito charmosas; } \\
\text { Existem boas opções de hospedagem. }\end{array}$ \\
\hline Alimentação & $\begin{array}{l}\text { Falta opções de restaurantes; } \\
\text { A comida é boa, o atendimento e higiene são ruins. }\end{array}$ \\
\hline Preços & Valores bem acessíveis. \\
\hline Segurança & Não existe, cada um cuida de si. \\
\hline Serviços Médicos & Não existe. \\
\hline $\begin{array}{l}\text { Serviços de } \\
\text { Comunicação }\end{array}$ & $\begin{array}{l}\text { Precário. Não existe telefonia convencional e o sinal de celular é } \\
\text { ruim, às vezes o povoado fica isolado. }\end{array}$ \\
\hline Atendimento & $\begin{array}{l}\text { Falta preparo e profissionalismo. } \\
\text { Ainda não está profissionalizado. }\end{array}$ \\
\hline Transporte & $\begin{array}{l}\text { Existe apenas um ônibus por dia, que passa em São Jorge e o } \\
\text { Povoado não dispõe de carros de aluguel. }\end{array}$ \\
\hline Infra-estrutura & $\begin{array}{l}\text { Considerando-se que é uma vila muito pequena e simples; } \\
\text { Água, energia, iluminação pública, atendimento de saúde, centros } \\
\text { de informação, opções noturnas e comunicação são muito } \\
\text { precários. }\end{array}$ \\
\hline Acesso & $\begin{array}{l}\text { A estrada que dá acesso ao Povoado não tem pavimentação e tem } \\
\text { sérios problemas de manutenção, o que desencoraja muitas pessoas } \\
\text { a visitarem o Parque. Ocorre grande número de acidentes fatais por } \\
\text { causa do tipo de cascalho usado, que não dá compactação. }\end{array}$ \\
\hline
\end{tabular}

Ao final do questionário foi aberto às operadoras espaço para outros comentários sobre o Parque e sobre o Distrito de São Jorge, destacando-se :

* na nossa opinião a terceirização dos serviços e atividades é positiva. Normalmente é mais fácil dialogar com o setor privado, menos burocrático do que com órgão público, cheio de normas e de pessoas interessadas apenas em sua carreira. Se os critérios de uso público forem bem definidos no processo de terceirização, só teremos a ganhar. Haverá maior exigência de qualificação dos condutores e da prestação de todos os serviços.

- são três os segredos para viabilizar o PNCV: segurança, estrutura e divulgação, pois o produto é muito bom! 


\section{5 - CONSELHO DO PARQUE}

Em 05 e 06 de setembro, considerando convite recebido para reunião do CONPARQUE a autora participou da mesma, onde se destacaram temas como a preocupação com a forma que vem se dando a condução de visitantes no Parque, a situação das trilhas e a terceirização dos serviços e atividades no mesmo.

Segundo a Diretora do Parque, o perfil do público mudou muito para melhor nos últimos anos, no entanto o grande problema que o Parque vem enfrentando é com os condutores. $\mathrm{O}$ fato de hoje a Unidade não contar com condutores em número suficiente para atendimento ao fluxo de visitantes, pois muitos não tem compromisso com o trabalho, tem trazido grandes problemas para a direção do Parque. Segundo a Diretora, talvez o que falte seja a concorrência, pois não existe comprometimento, o condutor marca com o visitante e não aparece. $\mathrm{O}$ desempenho das funções muitas vezes não é compatível com a expectativa do visitante.

A Diretora levantou ainda o aspecto de que por outro lado, as operadoras tem se preocupado com isto e tem investido na formação de condutores para seu próprio atendimento, sendo o nível desses condutores considerado muito bom pela direção do Parque.

Segundo informações da direção do Parque, hoje existem cerca de 150 condutores credenciados, mesmo assim em certas ocasiões esse número é insuficiente. É necessário portanto aumentar o número e treinar os condutores. O condutor tem que ter compromisso, há a necessidade de avaliação e capacitação dos mesmos, dentro de linguagem e metodologia apropriadas. Dar noções básicas de inglês, cursos diversos de fauna, flora e outros dados da região.

Segundo um dos membros do Conselho, as atividades ecoturísticas propiciadas pelo Parque, conseguiram envolver a comunidade, transformando garimpeiros em condutores, possibilitando uma oportunidade de trabalho para tantos que se viram sem atividade econômica para seu sustento após o declínio do garimpo.

No entanto a maioria presente concordou que atualmente os condutores se encontram muito acomodados, deixando muito a desejar em qualidade e compromisso com o serviço.

Vários membros do Conselho comentaram o fato de que a tradição do garimpo é uma cultura de individualismo, que não se conseguiu superar ainda, motivo da falta de compromisso com o trabalho por parte de vários condutores. Além disto, as pessoas mudaram da atividade garimpeira ou outra atividade local insipiente onde realmente passavam fome, para serem condutores e o foram durante alguns anos. 
Atualmente, muitos passaram a atuar em atividade comercial em função do fluxo de visitantes, trabalhando com pousada, camping e restaurante. Isto minimizou o problema econômico e portanto a atividade de condutor no Parque deixou de ser tão importante para alguns.

Segundo o Sr. Elmo Soraggi, da Subsecretaria de Turismo da Prefeitura de Alto Paraíso, e também condutor no Parque "o ecoturismo tem que envolver a comunidade, mas a comunidade também tem que querer. Querer, querer mesmo. Querer fazer curso, correr atrás, investir mesmo".

Foi discutido ainda, a questão em relação às operadoras, no sentido de que vendem o pacote, incluindo o Parque e muitas vezes quando chegam não podem entrar, pois a lotação está esgotada. Foram apresentadas duas sugestões para a solução do problema que seriam a reserva antecipada de ingresso ou o uso de voucher.

Outro aspecto considerado foi a falta de informações básicas que não são disponibilizadas ao visitante, tais como horário de funcionamento do Parque e suas regras, que poderiam estar disponibilizadas nas diversas pousadas, nos Centros de Atendimento ao Turista - CAT, e por meio dos condutores, visando minimizar problemas com os visitantes.

Foi considerado ainda na reunião, a necessidade de capacitar o pessoal da região para o artesanato, alimentação e outras atividades locais, pois o turista procura e não encontra produtos regionais para comprar, uma vez que a maioria vem de fora.

Sobre as trilhas, foi constatada que a situação atual é precária, muitas estão erodindo cada vez mais. Foi citada a descida das Cariocas como exemplo, que é de difícil acesso, necessitando de recuperação urgente.

Foi apresentado o tema sobre Terceirização de Serviços e Atividades em Unidades de Conservação e explicado que tudo é feito de forma transparente e participativa, que o Conselho será ouvido e posteriormente toda comunidade. Discutido com o membros do Conselho os benefícios, problemas e perspectivas da terceirização nos parques nacionais.

Ressaltado o aspecto de que a terceirização ajuda a minimizar problemas como os hoje existentes de quantidade e qualidade de serviços como o dos condutores, da falta de apoio mínimo ao visitante. A necessidade de que a população organize-se para participar do processo de licitação, uma vez que todo e qualquer serviço e/ou atividade pública só pode ser passada para execução por parte de terceiros mediante processo licitatório, foi também informada. 


\section{6 - ENTREVISTA COM CHEFIAS DE UNIDADE DE CONSERVAÇÃO}

No dia 23 de junho de 2002 em visita ao Parque, quando de trabalho de campo do CET/UnB, foi procedida por um dos grupos de trabalho entrevista com a responsável pela Área de Proteção do mesmo, Sra. Carmem Florêncio, e os pontos principais abordados pela mesma com relação à Unidade foram:

1 - a dificuldade por parte do Parque no bom desempenho de suas atividades, devido a escassez de funcionários, que acabam despendendo muito tempo em função da visitação. Daí ser de fundamental importância para a solução desse problema a terceirização de serviços e atividades no Parque;

2 - $\quad$ sobre a capacidade de carga estabelecida de 300 visitantes dia, podendo chegar a 350 em casos excepcionais;

3 - a limitação de idade mínima de oito anos para os visitantes, visando evitar transtornos;

4 - que os condutores de visitantes são credenciados pelo IBAMA, mediante prova de conhecimento físico do PN e aptidões inerentes ao perfil necessário para o bom desempenho das atividades, sendo em número de 160 dentre eles 30 encarregados de busca, salvamento e primeiros socorros;

5 - que os primeiros condutores foram treinados pelo IBAMA e atualmente o treinamento é promovido pela Associação Bioma do Cerrado;

6 - que a administração do Parque tem um bom relacionamento com a comunidade local e com o Conselho Consultivo do Parque;

7 - que os principais problemas enfrentados pelo PN são a entrada ilegal, o monitoramento e manutenção das trilhas, energia deficiente, custo de vida alto no Distrito de São Jorge, assistência médica precária, falta de telefone fixo e fax, falta de segurança para guarda dos recursos arrecadados, dificuldade na aquisição de materiais diversos;

8 - $\quad$ a existência de uma proposta de terceirização de serviços previsto no Plano de Uso Público, que inclui transporte até as proximidades dos atrativos de forma a viabilizar o acesso de visitantes deficientes e idosos e também a implantação de serviços de alimentação no interior da Unidade;

9 - que o Parque conta com serviços terceirizados de dois funcionários de limpeza, dois motoristas, dois administrativos e dois vigilantes;

10 - que o relacionamento com os condutores é razoável e administrável, havendo pequenos conflitos de interesse, como por exemplo a sinalização das trilhas. 


\section{5 - CONCLUSÕES E RECOMENDAÇÕES}

\section{1 - CONCLUSÕES}

Os resultados do estudo com os visitante no Parque, demonstram que o público está mais interessado nos banhos de cachoeira que propriamente em ecoturismo. Talvez isso seja uma consequência do nível educacional e econômico dos entrevistados e a baixa expectativa em relação aos serviços e atividades existentes no Parque e no Distrito de São Jorge.

Um dos maiores desafios observados, utilizando as técnicas de pesquisa desta metodologia, foi quando da avaliação de algumas observações dos entrevistados, de certa forma incoerentes, fato esse evidenciado pelas respostas que consideraram atividades e serviços inexistentes no Parque, tais como alimentação, centro de visitantes e informações, como "muito bons", o que pode ser resultado do fato de o questionário ter sido preenchido diretamente pelo pesquisado.

Por outro lado, percebe-se de qualquer forma o interesse dos mesmos na manutenção e preservação dos atrativos e belezas naturais, inclusive pela preocupação detectada através do equipamento/serviço que gostaria de encontrar no Parque, onde existe um peso maior para as lixeiras.

Também pode ser visto pela resposta sobre outros tipos de serviços e equipamentos que o visitante gostaria de encontrar no Parque, o interesse dos mesmos na locação de equipamentos principalmente de mergulho, na demanda por transporte, água, trilhas voltadas para o conhecimento dos recursos naturais e por palestras sobre a Unidade.

Por outro lado, quando se depara com a pesquisa respondida pelas operadoras, pode se verificar um diferencial grande com relação às respostas obtidas junto com os visitantes. Ressalve-se que as operadoras não costumam levar seus clientes em épocas de alta temporada, pelo risco de não conseguir acesso ao parque.

As demandas das mesmas voltam-se para infra-estrutura mínima, disponibilização de mais atividades e serviços, capacitação de mão-de-obra local e abertura de novos atrativos.

Verifica-se um número ainda muito pequeno de empresas que operam com o Parque, quando constata-se a existência no país de mais de 200 operadoras trabalhando com ecoturismo em diversos parques, o que pode sinalizar a falta de divulgação do mesmo, a falta de infra-estrutura e a pouca diversidade de atividades.

Por outro lado, constata-se, conforme reunião do CONPARQUE, que a própria direção do Parque, admite que as operadoras são uma clientela especial, que não trazem qualquer tipo 
de problemas para a Unidade, inclusive cuidando do treinamento e capacitação dos condutores que trabalham com as mesmas.

Está aí portanto, um grande filão a ser explorado pela Unidade, tentando buscar mais parceiros conscientes e interessados na melhoria da estruturação e administração o que poderia levar a um resultado positivo para a UC, para a comunidade local e para os ecoturistas.

Com relação ao PUP, constata-se que as instituições governamentais já com parcos recursos, acabam investindo em instrumentos de planejamento que não são implantados e por isso não se consolidam, como é o exemplo do PAE, do PM e do próprio PUP. Esses documentos foram elaborados, aprovados, mas na área de uso público não tiveram suas propostas até o momento implementadas.

O PM já propunha a abertura de várias trilhas e implantação de atividades e serviços diversos, programas de educação ambiental, informação e maior integração com a comunidade, além de infra-estrutura mínima para atendimento aos visitantes. O PUP veio reforçar o PM e ampliar suas possibilidades, inclusive com detalhamentos e projetos para obras, sinalização, placas interpretativas, programas de divulgação, propostas para implementação do Parque, no entanto dois anos se passaram e nada foi concretizado.

É clara e notória a dificuldade por que passam os órgãos públicos, principalmente os ambientais, no sentido da gestão das atividades sob seu encargo, neste sentido, vários mecanismos existem para ajudar a minimizar estes problemas, como é o caso da terceirização de serviços e atividades.

A modalidade de terceirização é utilizada em áreas protegidas em todo mundo e no Brasil já em alguns parques nacionais, de forma incipiente, mas já dando bons resultados, como é o caso dos Parques do Iguaçu no Paraná, Sete Cidades no Piauí e Intervales em São Paulo. É preciso buscar formas de viabilizar o Parque para o cumprimento dos seus objetivos, e um deles sem dúvida alguma é possibilitar aos visitantes seus uso ecoturístico.

A terceirização dos serviços e atividades do Parque, sem dúvida, propiciará melhor qualidade, maior diversidade, otimização dos recursos humanos da Unidade, que desobrigadas de certas atribuições, poderão se dedicar mais à proteção, pesquisa e monitoramento da UC e, ainda, o aumento da receita gerada pela Unidade, possibilitando a entrada de mais recursos para a manutenção e gestão do Parque.

Outro aspecto relevante da terceirização é o fomento à visita ordenada, com padrões de qualidade condizentes com a UC e a garantia de um acompanhamento e monitoramento da visitação de forma eficiente, trazendo lucros financeiros, ambientais e educativos.

Outro aspecto a ser comentado diz respeito aos resultados obtidos nas visitas de campo para avaliação dos atrativos, serviços e atividades, que demonstraram a inquestionável beleza 
dos atrativos, o potencial ecoturístico do Parque e a grande demanda de visitação que, no entanto, se depara com a falta de condições mínimas para um atendimento de qualidade.

$\mathrm{Na}$ realidade o que se constata é que a pressão pelo uso ecoturístico chegou e o Parque não conseguiu se estruturar para aproveitar esta demanda tão rica e tão importante para o mesmo, seja sob o ponto de vista social, ambiental, educacional ou mesmo econômico.

O PNCV é um dos parques de maior visibilidade do Sistema Nacional de Unidades de Conservação, é, um dos doze parques mais visitados do país e, segundo as operadoras e a literatura consultada, existe uma tendência cada vez mais crescente de ampliação de sua busca pelos ecoturistas.

Portanto, analisando o Parque com base nos seus atrativos, nas suas condições gerais, nos seus instrumentos de planejamento e na sua venda pelas revistas, Internet e pelo próprio EMBRATUR como produto ecoturístico, pode-se chegar às seguintes conclusões:

* que o Parque possui atrativos naturais de imensa beleza;

* que a Unidade possui potencial muito maior do que o hoje explorado, no entanto ainda não desenvolvido e disponibilizado ao público;

* que a UC possui possibilidade de atender a diversos segmentos da sociedade, seja no campo da recreação, da cultura, científico, educativo, místico e outros;

* que o Parque bem administrado, possui condições de gerar benefícios ambientais, sociais e econômicos para a região, a comunidade local e para o SNUC de uma forma geral; e

* que o Parque possui todas as condições físicas para vir a ser um grande destino ecoturístico no país.

No entanto, considerando o conceito de ecoturismo, o conceito de pólos de ecoturismo, conclui-se que o PNCV ainda não é um produto ecoturístico, que tem todo potencial para vir a ser, mas que necessita ser dotado de condições mínimas para atender a esta demanda cada vez mais crescente.

Analisando e comparando, ainda, algumas respostas obtidas, verificamos a coincidência de alguns pontos relevantes apontados pelas operadoras, pelo Conselho Consultivo do Parque, pelo PUP, pela direção da Unidade e pela visita de campo realizada, que são:

* a necessidade de maior compromisso, ou seja profissionalismo e qualificação dos condutores;

* a necessidade de monitoramento e melhoria das trilhas existentes e em estado de erosão bastante acelerado; 
* a necessidade de disponibilização de informações e divulgação sobre o parque e seu funcionamento; $\mathrm{e}$

* a necessidade de um aporte maior de segurança aos visitantes.

Estes tópicos levam à conclusão da necessidade urgente de medidas por parte do órgão responsável no sentido de sanar estas e outras dificuldades apontadas e imprescindíveis para a implementação das áreas de uso público da Unidade.

O PNCV corre um grande risco de degradação pela pressão da visitação, pela escassez de recursos humanos e financeiros, que impedem que o mesmo cumpra plenamente com suas funções básicas.

Assim é que a conclusão maior deste estudo é de que o PNCV tem potencial, mas, dentro daquilo que se espera de um destino ou produto ecoturístico, o mesmo tem todo um caminho a ser percorrido, visando implementá-lo de forma a torná-lo seguro para o meio ambiente e para os visitantes, torná-lo viável economicamente, torná-lo exemplo de Unidade de Conservação no Planalto Central.

Pretende-se que este trabalho contribua para que:

1 - o Parque tenha subsídios técnicos para implementação de ações que de fato viabilizem o mesmo no âmbito do ecoturismo;

2 - o IBAMA possa definir política para este e outros parques no Brasil, visando sua adequação ao atendimento público; e

3 - que esta experiência com seus pontos positivos e negativos seja utilizada pelo IBAMA na implementação de ações para este e outros parques no Brasil.

\subsection{RECOMENDAÇÕES E SUGESTÕES}

Em função de todas as pesquisas, estudos e conclusões, várias são as sugestões que este estudo propõe, conforme descrito a seguir.

Que seja dada prioridade com a máxima urgência à implementação das várias ações propostas no PM e PUP na área já estudada, visando disponibilizar o Parque ao uso público de forma segura e mais condizente com a realidade de um parque nacional.

Que após a implementação acima citada, seja estudada na revisão do Plano de Manejo a possibilidade de abertura de Portões de entrada dando acesso à área do Parque, pelos municípios de Cavalcante, Nova Roma e Terezina de Goiás, visando distribuir mais os visitantes nas áreas Parque. Assim, minimizam-se os impactos causados pela pressão sobre as 
poucas opções hoje existentes, possibilitando com certeza impulsionar o desenvolvimento desses municípios, com melhoria da qualidade de vida e geração de renda para as comunidades dos mesmos.

Esta proposta se justifica, com base nas informações de moradores da região e dados da expedição realizada por uma equipe de reportagem da revista Terra, motivo da Reportagem "MAIOR ABANDONADO", publicada na edição de outubro de 2002, onde é informado sobre a grande quantidade de atrativos existentes nessas áreas.

Que sejam estudadas possibilidades de abertura de novas atividades no Parque, na área atual de uso público, conforme já indicado pelo PUP, visando minimizar a pressão atual nos únicos atrativos hoje visitados pelo publico.

Que sejam efetuados estudos de capacidade de carga para cada área a ser aberta e para as já em uso, visando minimizar os impactos atuais causados pela pressão por parte dos visitantes que querem e têm o direito a conhecer as belezas desse patrimônio nacional .

Que seja implantado o centro de visitantes, contemplando área de exposição, sala de multiuso para palestras, vídeos, apresentação de eslaides e outros. Também se faz necessária a implantação de sanitários, inclusive apropriados para portadores de deficiências físicas, bebedouros, lanchonete, loja de artesanato para divulgação e venda de produtos regionais e de materiais com marca ou logomarca do Parque, e ainda de produtos necessários aos visitantes que muitas vezes se deslocam sem todo o material mínimo necessário para sua segurança e satisfação quando da visitação dos atrativos da Unidade.

Que seja implementado um programa de sensibilização e capacitação para a população do entorno, no sentido de mobilizá-los na busca do ecoturismo, como uma alternativa de desenvolvimento sustentável para a região.

Que seja implementado um programa de educação ambiental voltado aos visitantes, visando sensibilizá-los para a importância do meio ambiente preservado no local, no país e no mundo.

Que sejam disponibilizadas trilhas interpretativas, e serviços que propiciem o aumento do conhecimento por parte do visitante, com relação a biodiversidade existente no PNC.

Que a administração do Parque se articule com outras instituições públicas e privadas, como ONG, SEBRAE, EMBRATUR, IPHAN e outros, no sentido de buscar maior capacitação para a comunidade local, na área de artesanato, gastronomia, cultura e outras no sentido de propiciar maiores condições à população local no que diz respeito à geração de emprego e renda.

Que sejam implantados serviços mínimos de atendimento aos idosos, portadores de deficiências físicas e crianças, parte representativa da população brasileira que, como assegura 
a constituição, têm direito ao meio ambiente e a conhecer e desfrutar de suas belezas e atrativos.

Que sejam implantadas trilhas autoguiadas voltadas para a contemplação e conhecimento das espécies da fauna, flora e das características geomorfológicas, possibilitando ao visitantes conhecer parte da rica biodiversidade do nosso país.

Que sejam implantadas trilhas que permitam aos cidadãos optarem conforme sua capacidade física, idade e tempo, conhecer no mínimo algumas belezas cênicas existentes no Parque.

Que sejam aproveitados os recursos naturais existentes no que diz respeito a prática do rapel, canionismo e outras atividades na natureza, no sentido de dotar o Parque de novas e diferenciadas atividades compatíveis com o meio ambiente e a categoria de manejo.

Sugere-se ainda, o estudo de um plano de terceirização de atividades e serviços, visando minimizar os problemas de carência de recursos humanos e financeiros, melhorar a qualidade dos serviços e maximizar a utilização do potencial do Parque.

Que, seja elaborado e efetivado, plano de divulgação do Parque, após as implementações necessárias, às operadoras e empresas de ecoturismo, visando promover a UC como produto ecoturístico.

Entende-se que um dos aspectos a serem trabalhados pelo poder público com a máxima urgência é a implantação de infra-estrutura mínima, seja através de recursos próprios, seja através de recursos advindos de compensação ambiental que a UC está recebendo, seja por meio da terceirização das atividades. Esta infra-estrutura mínima passa pela segurança do visitante, e pela qualidade nas condições da Unidade para atendimento às visitação;

Uma das melhores formas de captar a população como aliada e parceira da Unidade é o envolvimento da mesma, capacitando-a em todos os setores, seja ambiental ou empresarial, para que a mesma, receptora dos benefícios advindos do Parque passe a defendê-lo e protegêlo de fato como sua propriedade.

Melhorar o meio ambiente significa conscientizar as pessoas de sua importância na qualidade de vida, na manutenção da biodiversidade e na significância de que o meio ambiente preservado vale mais que a exploração de seus recursos finitos.

É necessário que novas formas de parceria amenizem ou superem os problemas das exclusões sociais atualmente existentes na área de estudo, principalmente por meio da capacitação e do envolvimento da população nas atividades do Parque.

A busca crescente por áreas protegidas indica, que, quanto antes essas áreas estiverem preparadas para o atendimento dessa demanda, menor o risco de impactos negativos sobre as 
mesmas, uma vez que é necessário e mais que isto, é um direito constitucional do cidadão o acesso ao patrimônio natural de seu país.

O ecoturismo é sem sombra de dúvidas a atividade mais vantajosa e mais eficiente para que as UC possam cumprir com parte de seus objetivos no que diz respeito à comunidade.

Por meio do ecoturismo é possível oferecer aos visitantes um tipo de recreação e lazer que além de propiciar o descanso, o desfrute das belezas cênicas, culturais e ambientais de forma harmônica, proporciona a possibilidade de ampliação do conhecimento. Possibilita a circulação da informação ambiental, fomenta a participação efetiva da comunidade na preservação do meio ambiente ajudando a formar uma consciência mais ambientalista e captando multiplicadores na defesa dos recursos naturais.

O ecoturismo é uma alternativa econômica que estimula o desenvolvimento local e regional de forma sustentável, contribuindo, desta forma, para o combate a pobreza através da geração de empregos e renda e da minimização da migração das populações locais para grandes centros urbanos.

Além desses fatores e outros mais, o ecoturismo é alternativa eficaz para conter a degradação do meio ambiente, uma vez que busca a integração e a conscientização das comunidades do entorno, do empresariado e dos visitantes, que envolvidos e cientes da importância de um meio ambiente preservado, se transformam de inúmeras maneiras em financiadores do manejo de áreas silvestres.

O PNCV precisa ofertar mais espaços de convívio harmônico com a natureza, não só porque é um direito do cidadão o acesso às suas belezas cênicas, mas porque é uma forma de manejar o uso dos recursos, que quando direcionados somente a um local causam impactos negativos imensos, como vem ocorrendo com as escassas trilhas que hoje são utilizadas no Parque.

O PNCV com facilidade pode vir a ser mais uma vitrine do meio ambiente para o Brasil e o mundo, para isto faz-se necessário, sem sobra de dúvidas, uma boa administração, apoio, autonomia e vontade.

Se parte destas propostas for utilizada no futuro pelo Poder Público e pela sociedade civil terá valido o esforço. 


\section{REFERÊNCIAS BIBLIOGRÁFICAS}

AGENDA 21. Conferência das Nações Unidas sobre Meio Ambiente e Desenvolvimento. 2.ed. Brasília, DF: Senado Federal, 1997.

AGENDA 21 brasileira. Ações prioritárias. Brasília-DF: MMA, 2002. 2v. v.2.

BOO, E. Ecotourism: the potentials and pitfalls. WWF, Washington, 1990. v.1.

BOO, E. The ecotourism boom, planning for development and management. Washington: WWF, 1992. v.2. (Technical Paper Series)

Ecotourism planning for protected areas. In: Ecotourism: a guide for planners and managers. LINDBERG, K. e HAWKINS, D.E. (Ed.). North Bennington: The Ecotourism Society, 1993. 175p. p.15-31. v.1.

BRASIL. Constituição (1988). Constituição da República Federativa do Brasil. Brasília, DF: Horizonte Editora. 1988, 2. ed..

Decreto $n^{o} 49.875$, de 11 de janeiro de 1961. Cria o Parque Nacional do Tocantins, no Estado de Goiás e dá outras providências. Brasília, DF, 1961.

Decreto $n^{\circ} 70.492$, de 11 de maio de 1972. Dá nova denominação ao Parque Nacional do Tocantins; altera dispositivos do Decreto $\mathrm{n}^{\circ} 49.875$, de 11 de janeiro de 1961, e dá outras providências. Brasília, DF, 1972.

Decreto $n^{\circ} .86 .173$, de 02 de julho de 1981. Altera os limites do Parque Nacional da Chapada dos Veadeiros. Brasília, DF, 1981.

Decreto $n^{\circ} 86.596$, de 17 de novembro de 1981. Retifica o Decreto $\mathrm{n}^{\circ} 86.173$, de 2 de julho de 1981, que altera os limites do Parque Nacional da Chapada dos Veadeiros. Brasília, DF, 1981.

Decreto de 27 de setembro de 2001. Amplia os limites do Parque Nacional da Chapada dos Veadeiros e dá outras providências. Brasília, DF, 2001.

Decreto $n^{\circ} 4.320$, de 22 de agosto de 2002. Regulamenta artigo da Lei $\mathrm{n}^{\circ}$ 9.985, de 18 de julho de 2000, que dispõe sobre o Sistema Nacional de Unidades de Conservação da Natureza - SNUC, e dá outras providências. 2.ed. aum. Brasília, DF: MMA/SBF, 2002.

Guia de Turimo Ecológico. Parques Nacionais. São Paulo: Empresa das Artes, 1999.

O desafio do desenvolvimento sustentável. Presidência da República. Comissão Interministerial para a Preparação da Conferência das Nações Unidas sobre Meio Ambiente e Desenvolvimento. Brasília, DF: CIMA, 1991. 
Portaria/IBAMA $n^{\circ}$ 62, de 20 de junho de 2001. Dispõe sobre as atribuições e composição do Conselho Consultivo do Parque Nacional da Chapada dos Veadeiros. Brasília, DF, 2001.

Portaria/IBAMA $n^{\circ}$ 82, de 26 de junho de 2001. Cria o Conselho Consultivo do Parque Nacional da Chapada dos Veadeiros. Brasília, DF, 2001.

CAVAlCANTI, K. Maior abandonado. Revista Os Caminhos da Terra, São Paulo, n.126, p.26-33, out. 2002.

CORAZOLLA, E. S. Ditadura internambiental. Jornal da Biosfera, Alto Paraíso de Goiás, 15 nov. 2001. Página 2.

EMBRATUR/UNIÃO EUROPÉIA . Manual de ecoturismo. Brasília: EMBRATUR, 1994.

EMBRATUR/IBAMA. Diretrizes para uma política nacional de ecoturismo. Grupo de Trabalho Interministerial - MICT/MMA. Brasília: EMBRATUR, 1994.

EMBRATUR/IEB. Pólos de ecoturismo: planejamento e gestão. São Paulo, 2001.

FARIA, Tiago. Conflito na Chapada dos Veadeiros. Correio Braziliense. Brasília, 31 jul. 2002. Disponível em: <http://www2.correioweb.com.br/cw/EDICAO_20020731/ pri_cid_310702_130.htm>. Acesso em: 21 mar. 2003.

FIGUEIREDO, Silvio L. Ecoturismo e desenvolvimento sustentável: alternativa para o desenvolvimento da Amazônia? In: FIGUEIREDO, Silvio L. (Org.). O Ecoturismo e a Questão Ambiental na Amazônia. Belém: NAEA/UFPA/NAEA, 1999. 224p. p. 75-126.

IBAMA/MMA. Roteiro metodológico de planejamento - parque nacional, reserva biológica, estação ecológica. Brasília, 2002.

KINKER, S. Ecoturismo e conservação da natureza em parques nacionais. Campinas: Papirus, 2002. (Coleção Turismo).

LEEUWENBERG, F. J. B. Plano de Uso Público: Parque Nacional da Chapada dos Veadeiros. Brasília: IBAMA, 2001.

LISTA das Unidades de Conservação Federais. Base de Dados SIUC/IBAMA Disponível em: <http://2.ibama.gov.br/unidades/geralucs/tabl.htm> . acesso em: 21 dez. 2002.

MAGAlHÃES, Guilherme W. (Coord.). Pólos de ecoturismo: Brasil. São Paulo: Empresa das Artes, 1999.

PÁDUA, S. M. et al. Ecoturismo e Conservação da Natureza. In: DE ROURE, M; PÁDUA, S. M. (Org.). Empreendedores em ação. São Paulo: Cultura, 2001.

PAES, M. L. N. Plano de ação emergencial: Parque Nacional da Chapada dos Veadeiros. Brasília: IBAMA, 1995. 
PAIVA, L. O. C. Ecoturismo Brasileiro. Revista Ecoturismo no Brasil. Brasília: Parque Nacional da Chapada dos Veadeiros. Banco de Dados do IBAMA. Disponível em: <http://www2.ibama.gov.br/unidades/parques/reuc/1015.htm> . acesso em: 12 mar. 2003.

Patrimônio Mundial. Reservas do Cerrado, Parque Nacional de Emas e Parque Nacional Chapada dos Veadeiros. Disponível em: 〈http://www.iphan.gob.br/bens/Mundial/p16.htm>. Acesso em: 14 mar. 2003.

PIMENTEL. A. P. M. et al. Plano de Manejo: Parque Nacional da Chapada dos Veadeiros. Brasília: IBAMA/PROAVES, 1998.

PIRES, Paulo dos S. Ecologia. A dimensão conceitual do ecoturismo. In: Turismo, Visão $e$ Ação. Itajaí: Univali, 1998. v. 1. n. 1. p. 75-91.

REUNIÃO ORDINÁRIA DO CONSELHO CONSULTIVO DO PNCV. Reunião Ordinária. Cavalcante, GO. 05 e 06 de set. 2002.

REVISTA VIAGEM E TURISMO. São Paulo, n. 80, jun. 2002. Edição Especial. O melhor do Ecoturismo: os 12 destinos verdes mais quentes do Brasil.

ROCKTAESCHEL. Benita Maria M. M. Marco Conceitual e Diretrizes para Terceirizações Administrativas em Unidades de Conservação. In: Guia do chefe - manual de apoio ao gerenciamento de unidades de conservação federais. Anexo 7 . Versão digital. Brasília: IBAMA/GTZ, 1999.

ROCKTAESCHEL. Benita Maria M. M. Terceirização em áreas protegidas: estímulo ao ecoturismo no Brasil. No prelo. 2003.

SERRANO, Celia Maria de T. A vida e os parques: proteção ambiental, turismo e conflitos de legitimidade em unidades de conservação. In: SERRANO, C.M.T \& BRUHNS, H.T. (Org.) Viagens à natureza. São Paulo: PAPIRUS, 1997. 152p. p.103-123.

SNUC. Sistema nacional de unidades de conservação da natureza. Lei $\mathrm{n}^{\circ}$ 9.985, de 18 de julho de 2000. Regulamenta o art. 225, $\S 1^{\circ}$, incisos I,II,III e VI da Constituição Federal, institui o sistema nacional de unidades de conservação da natureza e dá outras providências. 2.ed. aum. Brasília, DF: MMA/SBF, 2002.

SOAVINSKI, Ricardo José. O Programa de Desenvolvimento do Ecoturismo na Amazônia Legal - PROECOTUR. In: IV SEMINÁRIO DE TURISMO DA AMAZÔNIA. Manaus. 07 nov. 2002.

WOOD, Megan E. Ecotourism: principles, practices \& policies for sustainability. Paris: UNEP, 2002

ZIFFER, Karen A. Ecotourism: the uneasy alliance. Conservation International. Ernst \& Young,International Management Consulting Group - Working Paper on Ecotourism,1. Washington,DC: Island Press, 1989. 


\section{I - INFORMAÇÕES SOBRE A VISITA}

1. Viaja

凶Só

凶 Casal

凶 Família

凶 Agência de Turismo

凶 Grupo

2. Vezes que viaja por ano
凶 Até 2 vezes
凶 De 3 a 5 vezes
凶 Mais de 6 vezes

3. Número de visitas anteriores ao Parque
凶 Nenhuma
凶 De 3 a 5 vezes
凶 Mais de 10 vezes
凶 Até 2 vezes
凶 De 6 a 10 vezes

4. Tempo de permanência nesta localidade
凶 1 dia
凶 2 a 3 dias
凶 $\quad 4$ a 6 dias
凶 7 dias ou mais

5. Meio de Hospedagem
凶 Hotel
凶 Camping
凶 Casa alugada
凶 Pousada
凶 Casa de amigos
凶 Casa própria

凶 Outros - Citar:

6. Meio de Locomoção

凶 Carro próprio

凶 Carro alugado

凶 Ônibus - linha

凶 Moto

凶 Outros - Citar:

7. Atividades preferidas para praticar nesta localidade
凶 Banho no rio/cachoeira
凶 Trilhas
凶 Passeio pela área
凶 Contato com a comunidade
凶 Caminhadas
凶 Outros - Especificar :

8. Motivos da visita ao Parque

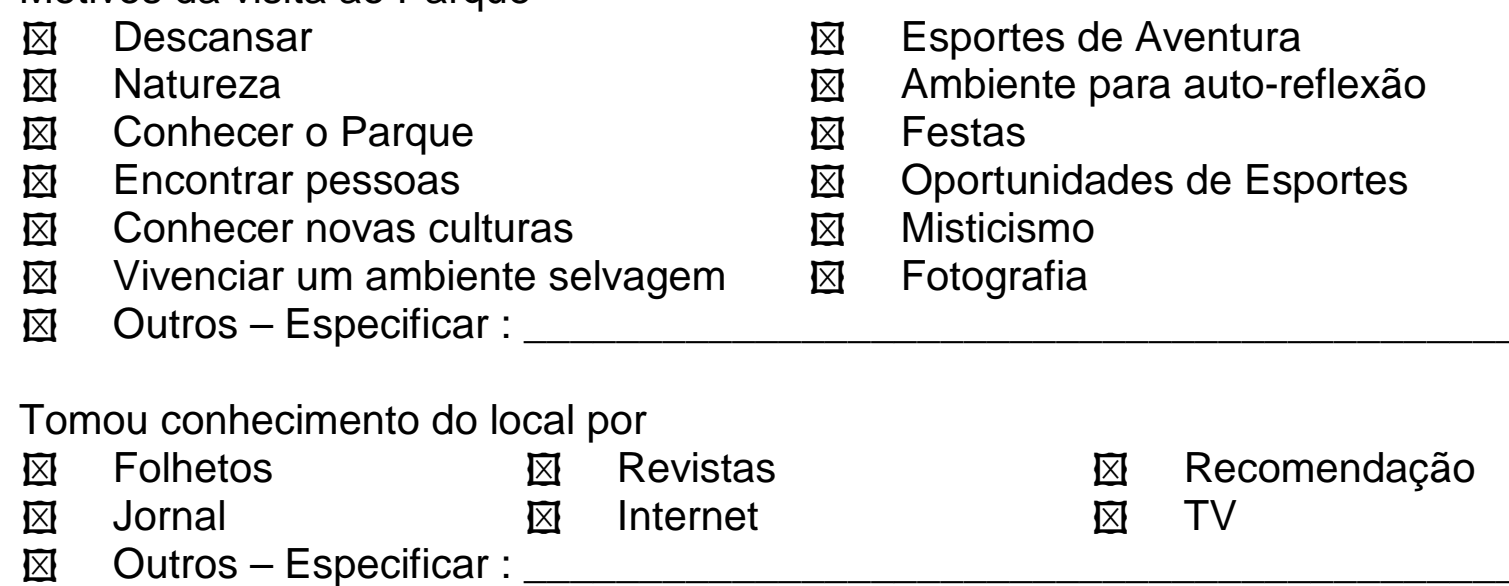


10. Sua opinião sobre as Atividades e Serviços do Parque

Notas : $0=$ inexistente; $1=$ ruim; $2=$ regular; $3=$ bom; $4=$ muito bom; $5=$ ótimo.

\begin{tabular}{|l|l|l|}
\hline Atividades / Serviços & Nota & Observações \\
\hline Acesso & & \\
\hline Alimentação & & \\
\hline Preços & & \\
\hline Limpeza & & \\
\hline Sinalização & & \\
\hline Trilhas & & \\
\hline Condutores & & \\
\hline Informações & & \\
\hline Segurança & & \\
\hline Atendimento & & \\
\hline Centro de Visitantes & & \\
\hline Outros - Especificar & & \\
\hline
\end{tabular}

11. Sua opinião sobre as Atividades e Serviços no Município de São Jorge Notas : 0 = inexistente; $1=$ ruim; $2=$ regular; $3=$ bom; $4=$ muito bom; $5=$ ótimo.

\begin{tabular}{|l|l|l|}
\hline Atividades / Serviços & Nota & Observações \\
\hline Acesso & & \\
\hline Alimentação & & \\
\hline Preços & & \\
\hline Limpeza & & \\
\hline Sinalização & & \\
\hline Hospedagem & & \\
\hline Segurança & & \\
\hline Informaçoses & & \\
\hline Atendimento & & \\
\hline Artesanato & & \\
\hline Meios de Comunicação & & \\
\hline Comércio - Serviços & & \\
\hline Outros - Especificar & & \\
\hline
\end{tabular}

12. Valor total gasto durante sua permanência deste local

- Hospedagem $\mathrm{R} \$$

- Transporte R\$

- Alimentação R\$

- Outros Especificar
- Compras

- Com condutores

- No Parque
$\mathrm{R} \$$

$\mathrm{R} \$$

$\mathrm{R} \$$

$\mathrm{R} \$$ 
13. Equipamentos / Serviços que gostaria de encontrar no Parque

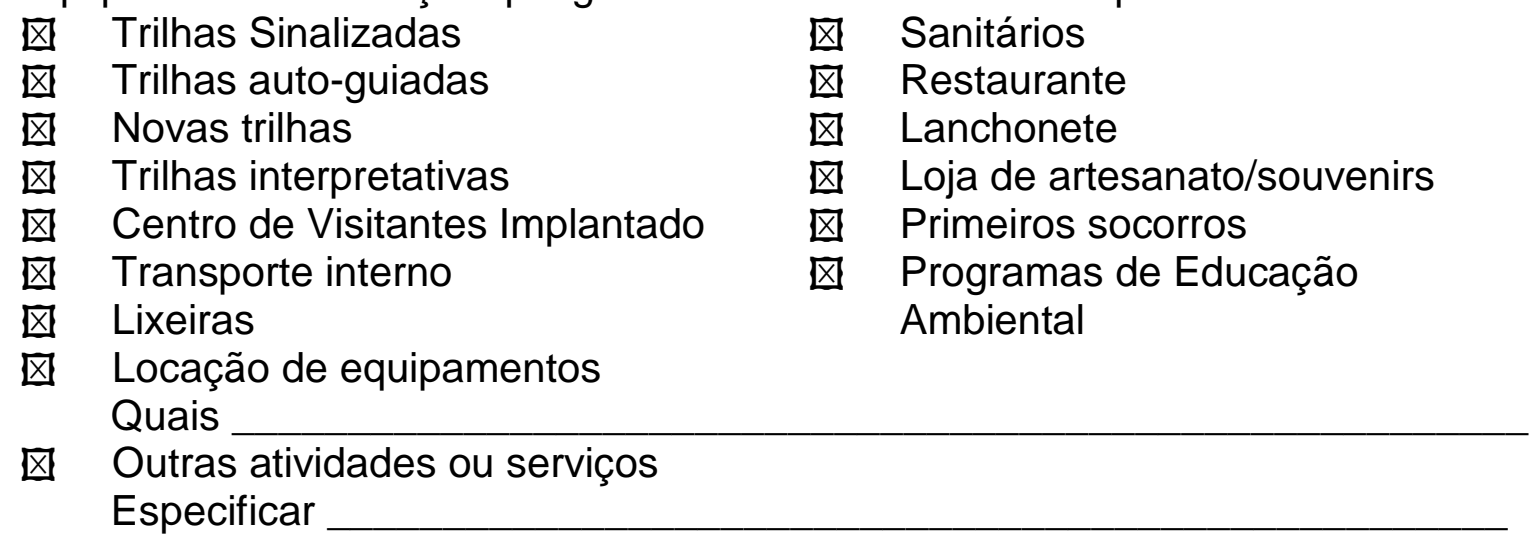

14. Seu nível de exigência em relação aos itens abaixo

Pontuar de 1 a 5 , considerando 1 = muito baixo e 5 = muito alto

\begin{tabular}{|l|l|}
\hline Itens & Pontuação \\
\hline Conforto & \\
\hline Atratividade da Natureza & \\
\hline Qualidade dos Serviços & \\
\hline Facilidade de Acesso & \\
\hline Segurança & \\
\hline Infra-estrutura de Hospedagem & \\
\hline Diversidade de Opções & \\
\hline Qualidade das Atracões & \\
\hline Limpeza & \\
\hline Preparo do condutores & \\
\hline Disponibilidade de Serviços e Equipamentos & \\
\hline Preservação da Natureza & \\
\hline Qualidade das informações & \\
\hline Preço & \\
\hline
\end{tabular}

15. Seu maior interesse com relação ao Parque e seu entorno
छsporte de Aventura
囚 Observação de fauna
Cultura local
凶 Observação da flora
凶 Culinária local
凶 Observação e contemplação da natureza

16. Sugestões e Observações

Data : 


\section{QUESTIONÁRIO QUANTITATIVO VOLTADO PARA OPERADORAS E AGÊNCIAS DE TURISMO}

Bom dia!

Meu nome é Benita.

Esta pesquisa que visa embasar projeto de monografia do Curso de Especialização em Ecoturismo da Universidade de Brasília. O objetivo é buscar entender melhor o mercado de turismo, as necessidades e preferências quanto à negociação de um novo destino ecoturístico. Sua empresa foi escolhida porque acreditamos que ela representa um importante papel nesse mercado. Sua participação é voluntária e de grande importância. O objetivo final do trabalho é tentar disponibilizar o Parque Nacional da Chapada dos Veadeiros para uso Ecoturístico, e para isto contamos com suas críticas e sugestões. As respostas são confidenciais e serão utilizadas de forma agregada para fins estatísticos

\section{I - DADOS DO ENTREVISTADO}

1. Nome da Empresa :

2. Nome do Entrevistado :

Cargo :

3. Telefone :

Fax : Email :

\section{II - DADOS DA EMPRESA}

1. Com que modalidade de turismo sua empresa trabalha prioritariamente ?
凶 Ecoturismo
凶 Turismo de Aventura
凶 Turismo Cultural
凶 Turismo Rural
凶 Outros

Quais?

2. Sua Empresa :

凶 Vende pacotes somente às agências de turismo

凹 Vende pacotes para agências e diretamente ao turista

3. Sua Empresa faz vendas pela Internet?

凶Sim

区 Não

4. Qual o volume aproximado de clientes que compra viagens ecoturísticas na empresa por ano?

凶 Até 200

凶 De 201 a 500

凶 De 501 a 700

凶 Acima de 701 


\section{III - SOBRE OS DESTINOS ECOTURÍSTICOS PRATICADOS}

1. Com quais destinos ecoturísticos a empresa trabalha mais ?

1)

2)

3)

4)

5)

2. A Empresa trabalha com Parques e outras Áreas Protegidas (RPPN, Florestas, etc.) ?

凶 Sim

Quais?

凶Não

Porque?

3. O Parque Nacional da Chapada dos Veadeiros em Goiás, está incluído no seu programa?

凶 Sim

区 Não

Porque?

4. Qual o nível de satisfação com os destinos ecoturísticos citados no item 1 acima ? Notas : 1 = ruim; 2 = regular; 3 = bom; 4 = muito bom; 5 = ótimo.

\begin{tabular}{|c|l|l|}
\hline Destinos & Nota & Observações \\
\hline 1 & & \\
\hline 2 & & \\
\hline 3 & & \\
\hline 4 & & \\
\hline 5 & & \\
\hline
\end{tabular}

5. Em comparação com os destinos acima citados, como você analisa a atratividade Turística do Parque Nacional da Chapada dos Veadeiros?
凶 Muito alta
凶 Média
凶 Bastante baixa
凶 Alta
凶 Baixa

6. Qual o preço médio do pacote contendo transporte, alojamento, tour e alimentação?

Faixas de preço : 1 = até $R \$ 500,00 ; 2=$ de $R \$ 501,00$ a $R \$ 1.000,00$;

$3=$ de $R \$ 1.001,00$ a $R \$ 2.000,004=$ Acima de $R \$ 2.000,00$.

\begin{tabular}{|c|l|l|}
\hline Destinos & $\begin{array}{l}\text { Preço médio do } \\
\text { pacote completo }\end{array}$ & \\
\hline 1 & & \\
\hline 2 & & \\
\hline 3 & & \\
\hline 4 & & \\
\hline 5 & & \\
\hline
\end{tabular}


7. Se você conhece o Parque Nacional da Chapada dos Veadeiros, como você avalia o mesmo para os itens abaixo ?

Notas : $1=$ ruim; $2=$ regular; $3=$ bom; $4=$ muito bom; 5 = ótimo.

\begin{tabular}{|l|l|l|}
\hline $\begin{array}{l}\text { Tipo de } \\
\text { Serviço/Atividade }\end{array}$ & Nota & Observações \\
\hline Atendimento & & \\
\hline Trilhas & & \\
\hline Centro de Visitantes & & \\
\hline $\begin{array}{l}\text { Atividades de } \\
\text { Educação Ambiental }\end{array}$ & & \\
\hline Preço & & \\
\hline Serviço de condutores & & \\
\hline Segurança & & \\
\hline Acesso & & \\
\hline Infra-estrutura & & \\
\hline Belezas Naturais & & \\
\hline
\end{tabular}

8. E a Vila de São Jorge ?

Notas : $1=$ ruim; $2=$ regular; $3=$ bom; $4=$ muito bom; $5=$ ótimo.

\begin{tabular}{|l|l|l|}
\hline $\begin{array}{l}\text { Tipo de } \\
\text { Serviço/Atividade }\end{array}$ & Nota & Observações \\
\hline Hospedagem & & \\
\hline Alimentação & & \\
\hline Preços & & \\
\hline Segurança & & \\
\hline Serviços Médicos & & \\
\hline $\begin{array}{l}\text { Serviços de } \\
\text { Comunicação }\end{array}$ & & \\
\hline Atendimento & & \\
\hline Transporte & & \\
\hline Infra-estrutura & & \\
\hline Acesso & & \\
\hline
\end{tabular}

9. Quais os fatores que você julga que promoveriam o aumento do fluxo de ecoturistas para o Parque?
凶 Preços mais acessíveis
凶 Maior divulgação e informação
Melhor acessibilidade
凶 Melhor infra-estrutura no Parque
凶 Melhor infra-estrutura da Vila de São Jorge
凶 Capacitação da mão-de-obra local
凶aior diversidade de Atividades/Serviços
囚 Outros - Quais?

10. Qual a sua opinião sobre a evolução do ecoturismo na região nos próximos anos ?

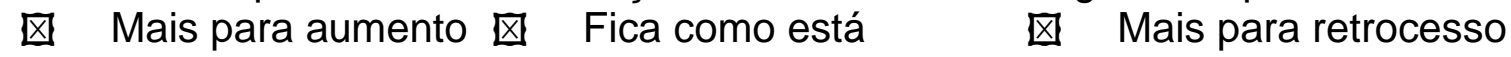


11. Caso você não trabalhe ainda com o Parque Nacional da Chapada dos Veadeiros, que fatores levariam você a vender o Parque como produto para seus clientes?

12. Quais os maiores problemas que você, como agência / operadora, vê para o produto ecoturístico do Parque Nacional da Chapada dos Veadeiros?

\section{IV - SOBRE O TURISTA}

1. Qual a origem da maioria dos seus clientes (país, estado, cidade, etc.)

2. O que o seu cliente normalmente busca em uma viagem ecoturística ?

\ Vivenciar a natureza (observar a flora e/ou fauna)

Q Praticar esportes de aventura (trekking, rapel, etc.)

区 Conhecer e aprender sobre o meio ambiente

凶 Conhecer e interagir com a cultura local

凶 Gastronomia local

囚 Outros. Quais ?

3. Qual o tipo de mídia você acredita ser mais eficiente para atingir os turistas ?

囚 Revistas especializadas

凶 Jornais $\quad$ 凶 Televisão

Q Mala direta

Outros. Citar

4. Como você avalia, de acordo com a sua experiência, a satisfação dos clientes com as visitas ao Parque?
凶 Grande
凶 Média
凶 Baixa

5. Quais as maiores críticas que você recebe dos turistas com relação ao Parque ?

6. Outros comentários que você gostaria de fazer sobre o Parque, São Jorge, etc.

7. Você gostaria de receber os resultados desta pesquisa? 凶Sim

凶Não

Obrigada por sua colaboração. 